


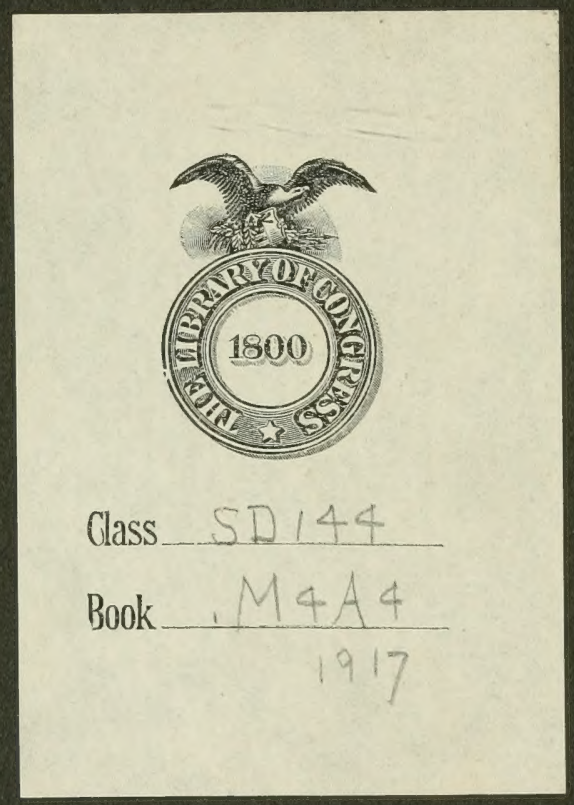




\section{THE FORESTS}

\section{OF WORCESTER COUNTY}

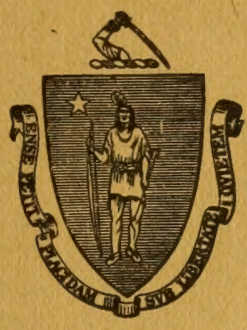

MASSACHUSETTS STATE FORESTER

1916

BOSTON

WRIGHT \& POTTER PRINTING CO., STATE PRINTERS 32 DERNE STREET

1917 




\section{The Forests of Worcester County}

\section{THE RESULTS OF A FOREST SURVEY OF THE}

FIFTY-NINE TOWNS IN THE COUNTY

AND A

STUDY OF THEIR LUMBER INDUSTRY

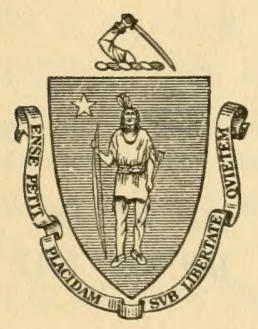

By H. O. COOK, M.F., Under the Direction of F. W. RANE, State Forester

Massachusetts, State Forester, 1916 "I

BOSTON

WRIGHT \& POTTER PRINTING CO., STATE PRINTERS

32 DERNE STREET 


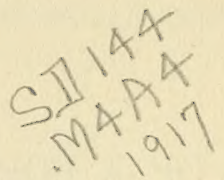

ApProved BY

The Supervisor of Administration.

D. of $\mathrm{D}$ 。

JAN $30 \quad 1917$ 


\section{FOREWORD.}

We are fortunate in being able to present herewith the forest survey of the towns composing Worcester County. This work has been in progress for the past three years, under the supervision of my assistant, Mr. H. O. Cook, M.F., who has had the assistance of several young men from various forestry schools who have worked largely during the summer vacations.

It is believed that these data will prove very valuable for present and future use in our State forestry development, and our purpose is ultimately to complete the work in the other counties of Massachusetts in the same way.

Nov. 2, 1916.

F. W. RANE, State Forester. 



\section{CONTENTS.}

Explanation of survey,

PAGE

Explanation of data:-

Size classes,

Forest types, 10

Open land types,

Worcester County,

Town forest conditions:-

Ashburnham,

Athol,

Auburn,

Barre,

Berlin,

Blackstone,

Bolton, .

Boylston,

Brookfield,

Charlton,

Clinton,

Dana,

Douglas,

Dudley,

Fitchburg,

Gardner,

Grafton,

Hardwick,

Harvard,

Holden,

Hopedale

Hubbardston,

Lancaster,

Leicester,

Leominster,

Lunenburg,

Mendon,

Milford,

Millbury,

North Brookfield, 
Town forest conditions - concluded.

Northborough,

Northbridge,

Oakham,

Oxford,

Paxton,

Petersham,

Phillipston,

Princeton,

Rutland,

Shrewshury,

Southborough,

Southbridge,

Spencer,

Sterling,

Sturbridge,

Sutton,

Templeton,

Upton,

Uxbridge,

Warren,

Webster,

West Boylston,

West Brookfield,

Westborough,

Westminster,

Winchendon,

Worcester, 


\section{THE FORESTS OF WORCESTER COUNTY.}

\section{Explanation of Survey.}

One of the first essentials in carrying on a business of any extent is an inventory showing the stock on hand. Our raw material in the forestry business in this State is our forest land. We have never had any thorough investigation which would answer the simplest question in this connection, - namely, how much of the area of this State is under forest cover and how much is tillage and pasture. About eleven years ago this department, in co-operation with the Massachusetts Bureau of Statistics, sent maps to the various town assessors and had them locate on these maps the forest land in their towns. Due partially to ignorance of conditions on the part of the assessors and partly to the impossibility of locating from memory all forest land on a small map, we found that the results of this investigation were very crude and unsatisfactory. A few towns were checked up, and the results showed that this investigation underran the actual forest area by 25 to 50 per cent. For this reason we have rejected these data as trustworthy bases of comparison, believing that the estimate of wellinformed people is more reliable. An investigation which shows simply the forest area as compared with the open land, while most interesting, has very little practical value. Such a survey to be of use must in addition show the amount of various species which compose the forest, and also the various ages and size classes. It is only with such information that we can make any estimate as to the present and future lumber and cordwood supply in this State.

It was with these conditions in mind that three years ago we decided to make a forest survey of Worcester County. This is not only the largest county in area, but is the most important 
from the forestry standpoint. Its woodlands produce the largest amount, and its wood-using industries consume the largest amount of native lumber of any county in the. State.

The forest surveying was done in the summer months by students of various forest schools. In this way we were able to get trained men at small expense. The work has taken more time than we anticipated, and was not completely finished until this summer. In the meantime, however, a similar survey of Plymouth County has been undertaken and will be completed this year.

\section{Method of Survey.}

Investigations similar to this have been attempted in other States, and the usual method of work has been for the men to traverse all the roads in each town and to sketch in the forest and open land on a base map provided for the purpose. We started our work on the same plan, but after completing a couple of towns changed our method. W' found that most of the open farming land lies along the roads, and that the bulk of the forest lies back of this open country. For this reason, while it is possible to sketch in boundaries of the forest land from the roadside, it is impossible to obtain any adequate idea of the composition, size and density of the woodland without actually traversing it. Such a system, therefore, did not give us the information that we most desired.

The method of field work finally used is an adaptation of a large-scale timber cruising system which we felt gare a maximum amount of information at a minimum cost. Each man worked one town at a time, running lines one-half mile apart by compass and pace from one boundary to the other. In a specially ruled notebook, on a scale of 1 inch to 1,000 feet, the length of each type as shown by the pace was recorded. Pantograph enlargements of government topographical sheets on a scale of 1,000 feet to an inch were used as a base map. The data on the notebooks were therefore easily transferred to the map. One of these maps is shown as a cut of the town of Bolton. (In the Plymouth County survey photographic enlargements of the topographic sheets on a scale of 2,000 feet to the inch were found satisfactory, and were more convenient to handle.) 
By means of symbols the species making up the type, by numbers the size, and by per cents. the density of stocking, are shown; for example, the following note on the line data, A E C, 2-3, 80, 700, means this: a mixed stand of pine, oak and chestnut, principally pine, of a size midway between Classes 2 and 3, 80 per cent. being fully stocked and extending over 700 feet of line run. In addition, there were special symbols representing chestnut bark disease, fire hazard, etc., if there chanced to be any present. The number of feet in each type, as compared with the total number of feet run in the town, is then proportioned into the total area of the town and the area of each type in acres calculated.

The data obtained in this way are very complete, and in working these up for purposes of publication it was necessary, for the sake of brevity, to exclude some, or to combine several different types and size classes. The complete data are all on file, however, and can be used whenever it appears to be worth while.

\section{Reports.}

In addition to the survey each examiner was asked to write a report on each town, covering his observations of the forest, topographical and soil conditions, lumbering and woodworking industries, timber prices, the names of principal landowners, forest-fire conditions, chestnut blight, gypsy-moth infestations, and everything which might be of interest to this department. These reports and the forest maps are on file in the office, and can be referred to whenever any forestry problem comes up in the town.

In order to limit the size of this bulletin it was decided that only those sections of the reports dealing with the forest conditions and wood-using industries should be published.

The following is a list of men who made these forest surveys and reports, with the towns in which they worked:-

David L. Dorward, . Brookfield, North Brookfield, Warren, West Brookfield.

HAROLd FAY, Auburn, Barre, Dana, Hardwick, Millbury, New Braintree, Oakham, Oxford, Worcester. 
Cedric H. Guise, . . . Dudley, Grafton, Holden, Leominster, Northbridge, Paxton, Princeton, Rutland, Shrewsbury, Spencer, Sterling, Sutton, West Boylston.

Walter G. Iles, Athol, Phillipston, Royalston, Templeton.

O. D. InGalls, Winchendon.

Herbert J. Miles, . Ashburnham, Gardner, Harvard, Westminster.

James Morris, . . Charlton, Hubbardston, Leicester, Petersham, Southbridge, Sturbridge.

J. R. Simmons, . . Boylston, Berlin, Bolton, Clinton, Douglas, Fitchburg, Lancaster, Lunenburg, Northborough, Southborough, Uxbridge, Webster, Westborough.

Lenthall Wyman, . . Blackstone, Hopedale, Mendon, Milford, Upton.

Explanation of Data.

\section{Size Classes.}

It is a difficult matter to divide the woodland into size classes and draw a hard-and-fast line between them. For purposes of classification we have recognized four classes, Class 1 being the largest and Class 4 the smallest. In the field intermediate classes were recognized, but in the final classification these have been included with one of the four principal classes. The illustrations are a help in recognizing these size classes.

Class 4. - This smallest class includes both seedling and sprout growth from one to twelve years in age, from 1 to 20 feet in height, and less than 2 inches in diameter. This class has no merchantable value, not even as cordwood.

Class 3. - This class includes growth of from twelve to thirty years of age, from 20 to 35 feet in height, and from 2 to 6 inches breast high diameter. With cordwood species such as oak and maple this type has a low merchantable value as a producer of small, low-grade fuel wood. There is no saw timber in this type, so that saw species, such as pine and chestnut, in this size class can be said to have no merchantable value.

Class 2. - This size includes trees from thirty to forty years of age, from 30 to 50 feet in height, and from 6 to 12 inches in 


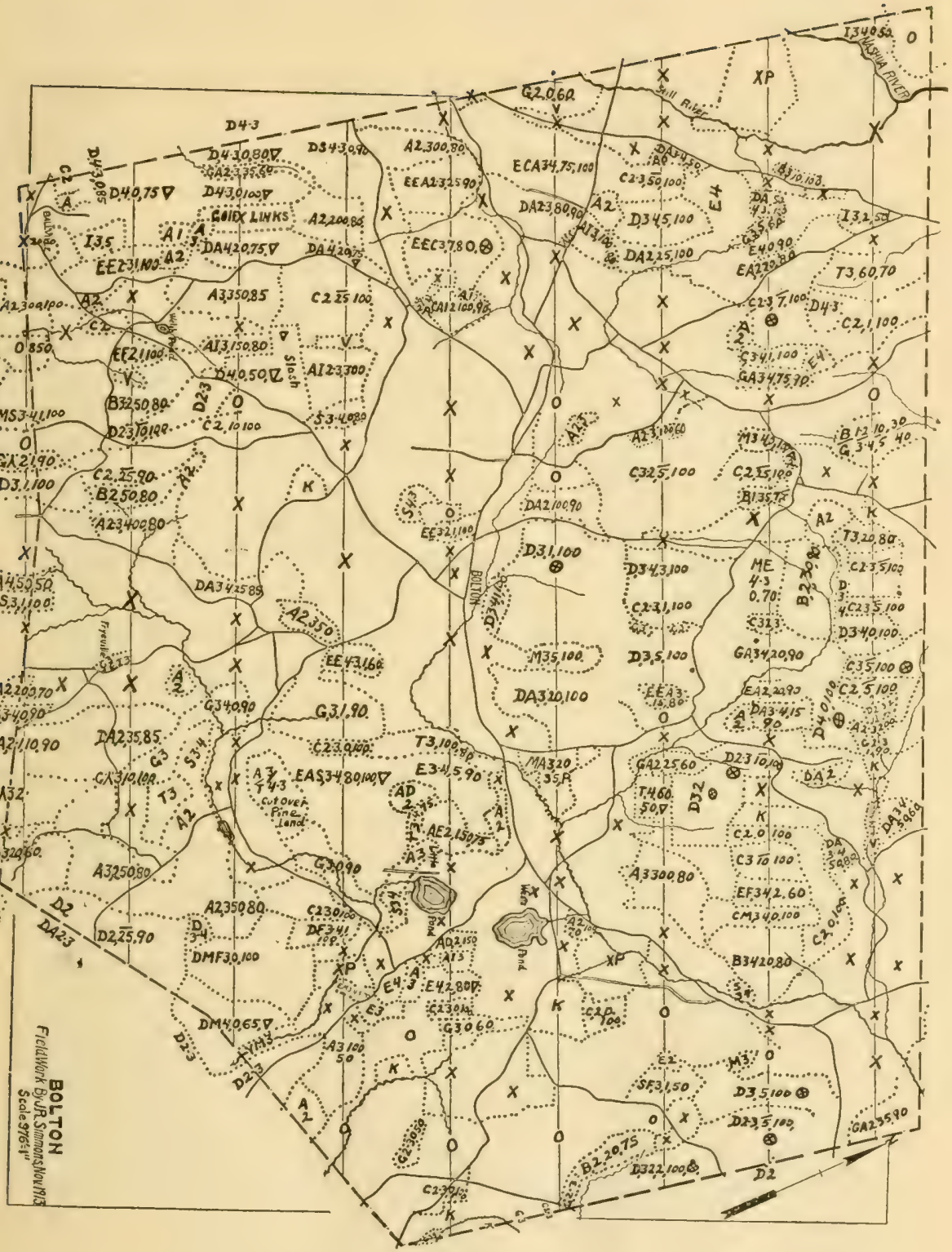


diameter. A stand of this class will produce first quality cordwood, and the chestnut and pine will make saw logs and cross ties.

Class 1. - This class includes all trees larger and older than the preceding sizes, and a stand in this class will be of saw-log size and of undoubted merchantable value.

\section{Forest Types.}

Although foresters are not agreed as to the exact definition of a forest type, it is usually understood to apply to the association of certain species which under certain site conditions of a general character are found growing together. In the woodlands of Worcester County, with their extraordinary abundance of species, it is possible to construct a great variety of types, and it is very difficult to combine these many types into group types of a number that can be contained in a printed table. We have divided the forest land of Worcester County into seven group types which we will define individually.

Chestnut. - This type is a simple one, consisting as it does of stands which contain at least 75 per cent. chestnut. The remaining 25 per cent. is usually oak, although there may be some pine or maple. When we speak of maple in this bulletin we refer to the red or soft maple, and do not refer to the hard or sugar maple unless it is specifically mentioned. Where pine or oak make up more than 20 or 30 per cent. of the stand, it is put in the pine and hardwoods or the chestnut and oak class.

Oak. - This type is described by its name, and, like the chestnut, a stand in this type is at least 75 per cent. oak. There is often a little chestnut or scattered pines in mixture, and in the younger age classes gray birch and maple; but unless they form more than 20 to 30 per cent. of the stand they are not considered. A smaller percentage of pine is taken into consideration than any other species, and if the stand is onefourth pine this percentage is enough to throw a stand of this type into the pine and hardwoods type.

Chestnut and Oak. - This type is described by the name, although there are almost sure to be a few other trees in the mixture, such as maple, hickory and an occasional pine. Chestnut, being the most vigorous grower, usually excels the 
oak in size and often in number. This is especially true in the older age classes, so that we recognize this type as a chestnut rather than as an oak type.

White Pine. - This type is more likely to be a pure stand than any of the others, although we put into this type any stand which is more than 60 per cent. pine. The hardwoods in mixture are usually birch, maple and oak. The pine, being the more vigorous grower, rapidly overtops the hardwoods, and before the oldest age class is reached has killed most of them, forming a pure stand.

Pine and Hardwoods. - Inasmuch as stands with more than 60 per cent. of pine have been put into the pure pine type it follows that the stands in this mixed type have, as a rule, rather more hardwood growth than coniferous. On the average the proportion of hardwood growth is 2 to 1 . The hardwoods usually found in mixture are gray birch, maple, oak and chestnut. The first three are more liable to be found in Classes 4 and 3 and the last three in Classes 2 and 1. In the northern part of the county there is considerable sugar maple, beech and white birch which will be found in this mixed type, especially in the older classes superseding oak and chestnut.

Gray Birch and Maple. - This type is a sort of miscellaneous affair into which we put the tag ends. We at first called it mixed hardwoods, but, finding that in 9 cases out of 10 the type consisted of a mixture of gray birch, maple and an occasional oak, decided to call it by that title. Gray birch exceeds the maple in the small classes and the maple exceeds the birch in the older classes. In the northern part of the county Classes 1 and 2 are likely to be largely sugar maple and white birch. This is the type which comes up on old run-out pastures. In swamps maple rather rules over birch, but not to so great an extent as might be supposed.

Conifers Other than White Pine. - This type usually includes both hemlock and pitch pine, not that there is any association between these species, but the aggregate amount of their area was too small to be separately classified. In a town where this type was almost entirely one of these species it is so named. In the north part of the county there is a good deal of spruce and tamarack in the swamps, which are included in this type. 


\section{Open Land Types.}

These types are pretty well described by their names, so that no discussion is necessary, except in one or two instances.

It is difficult to distinguish between open and brush pasture, as nearly all pasture has some brush growing in it. The directions to the examiners, however, were to include in brush pasture such lands as were so fully grown up with blueberry bushes, hardhack, sweet fern, etc., as to be about three-fourths covered with such brush growth. When pasture was stocking with a young growth of gray birch, maple, etc., it was included in the birch and maple, size 4, class, and for this reason the area of brush pasture may seem to be smaller than it should be.

In small towns it is a difficult matter to separate the area described as business and residential from the purely farming land, and in many very small communities no attempt was made to do so. Business and residential represent the area occupied by the village or urban section of the township.

Water areas are obtained from the topographical maps, and are not very trustworthy in many cases. The topographical survey was made forty years ago, and since then new dams have been built in brooks and rivers and new areas flooded, while, on the other hand, old dams which existed at that time have broken down and the mill ponds have disappeared. On the whole, we find that there is more water area than these maps show.

\section{Worcester County.}

Worcester County, the largest in the State, is located in the central part and extends from the New Hampshire line to the Connecticut and Rhode Island lines. The city of Worcester fittingly calls itself the heart of the Commonwealth. Three lines of railroad traverse it from east to west, - the Fitchburg Division of the Boston \& Maine in the northern part, the Central Massachusetts Division of the Boston \& Maine through the central part, and the Boston \& Albany in the southern section. These roads are cross connected by several small branch lines of the three main lines mentioned above, so that no part of the county is more than 10 miles from the railroad. 
Like all of Massachusetts, the principal business is manufacturing, although there is a considerable farming and dairying business carried on in the county. The manufacturing industries are quite varied, the principal ones being machinery,

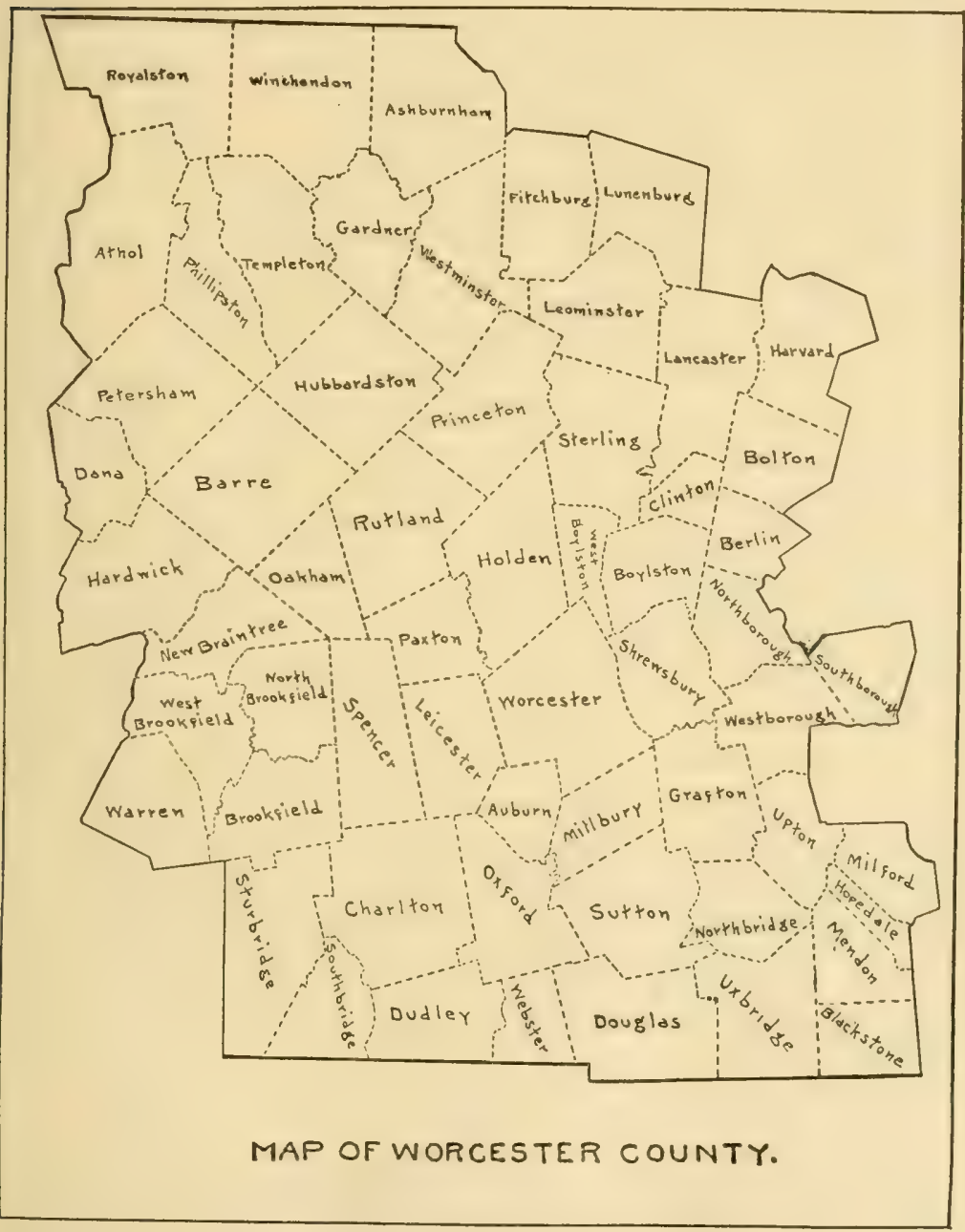

wire goods, textiles, - both cotton and wool, - paper, furniture and shoes. Worcester, the second city of the State, is the county seat, while Fitchburg, one of the larger communities of the State, contains the county offices for the northern district. 


\section{Topography.}

Worcester County is on the southern extension of those highlands which in New Hampshire form the divide between the Connecticut and Merrimack rivers. In Massachusetts all the streams on the west side of the divide drain into the Connecticut, while on the east side of the divide the streams in the north section drain into the Merrimack, and those in the southern section drain directly into the ocean. A line drawn from Ashburnham in the northeast corner of the county to Sturbridge in the southwest will about divide these two watersheds. The principal streams draining the western watershed are the Miller's, Ware, Swift and Quaboag rivers, while on the eastern side are the Nashua, which empties into the Merrimack, the Quinebaug, a tributary of the Nashua, the headwaters of the Assabet and Sudbury rivers, both of which are tributary to the Merrimack, and the Blackstone.

The general character of the topography is that of gently rounded hills with rather narrow valleys between. Occasionally these hills take the form of distinct ridges running north and south. This is especially the case in the southern part of the county, but on the whole there is little regular arrangement. Elevations are highest at the north end of the county, where they average between 1,000 and 1,200 feet above sea level, and decrease gradually towards the south, where they are between 700 and 800 feet in altitude. The most prominent hill is Mount Wachusett in Princeton and Westminster, which, with its elevation of 2,100 feet, dominates the entire hill country, and is the highest hill in Massachusetts east of the Connecticut River.

Soil.

In general the soil is a light sandy loam containing many stones. The top soil is underlaid by coarse gravel or hardpan. The better quality of soil is found on the hill slopes, while the valley bottoms are, as a rule, very sandy or gravelly. Low swamps and meadow lands have a black mucky soil, but these are of local occurrence. Although swampy areas are numerous 
they are of small extent, and the county may be said to be well drained. There are swamps of considerable area in the southern part of Brookfield and in the southern part of Auburn. The Nashua River valley in Lancaster has an extensive clay loam area distinct from anything else in the county. This area contains deposits of fuller's earth, a clay used in the scouring of woolen cloth. The soil is generally deep even on the hills, and outcropping ledges of the underlying rock are not common. This underlying rock is of igneous origin, either granite, schist or gneiss. About Milford the granite has a pinkish tinge and is called "Milford pink granite," and is much prized in some kinds of stone work, while in Fitchburg there are quarries of common gray granite cut chiefly into edgestones and block pavement.

Worcester County soil and topography would be favorable for agricultural development were it not for the great amount of stones and bowlders which make it impossible to work the soil with economy. For this reason much of the area must remain absolute forest soil. The soil on the whole is more favorable to conifers than to hardwood growth, although in low, moist situations and on north slopes deciduous growth thrives excellently.

\section{Forest Conditions.}

Worcester County is on the boundary line between the southern limit of what is called the northern forest typewhich contains, as hardwoods, beech, white and yellow birch and rock maple, and as conifers, white pine, hemlock, fir and spruce - and the northern edge of the southern forest region, whose type of trees includes chestnut, oaks, hickory, gray birch, red maple, white pine, pitch pine and hemlock. Lying as it does in this intermediate zone between these two forest regions its forest flora is very extensive. As explained before, it has been necessary to group these various species into types, and we give herewith a table showing the area of these forest types and nonforest types for the whole county. It will be seen from this table that the forest area covers more than one-half of the county, or 57 per cent. It will be noted with regret that the 
largest single type is that of the comparatively worthless maple and gray birch, but on the other hand two-thirds of the forest area is made up of types which contain saw species. Onequarter of this forest area is doomed to serious damage on account of the chestnut bark disease. 'Seven-tenths of the

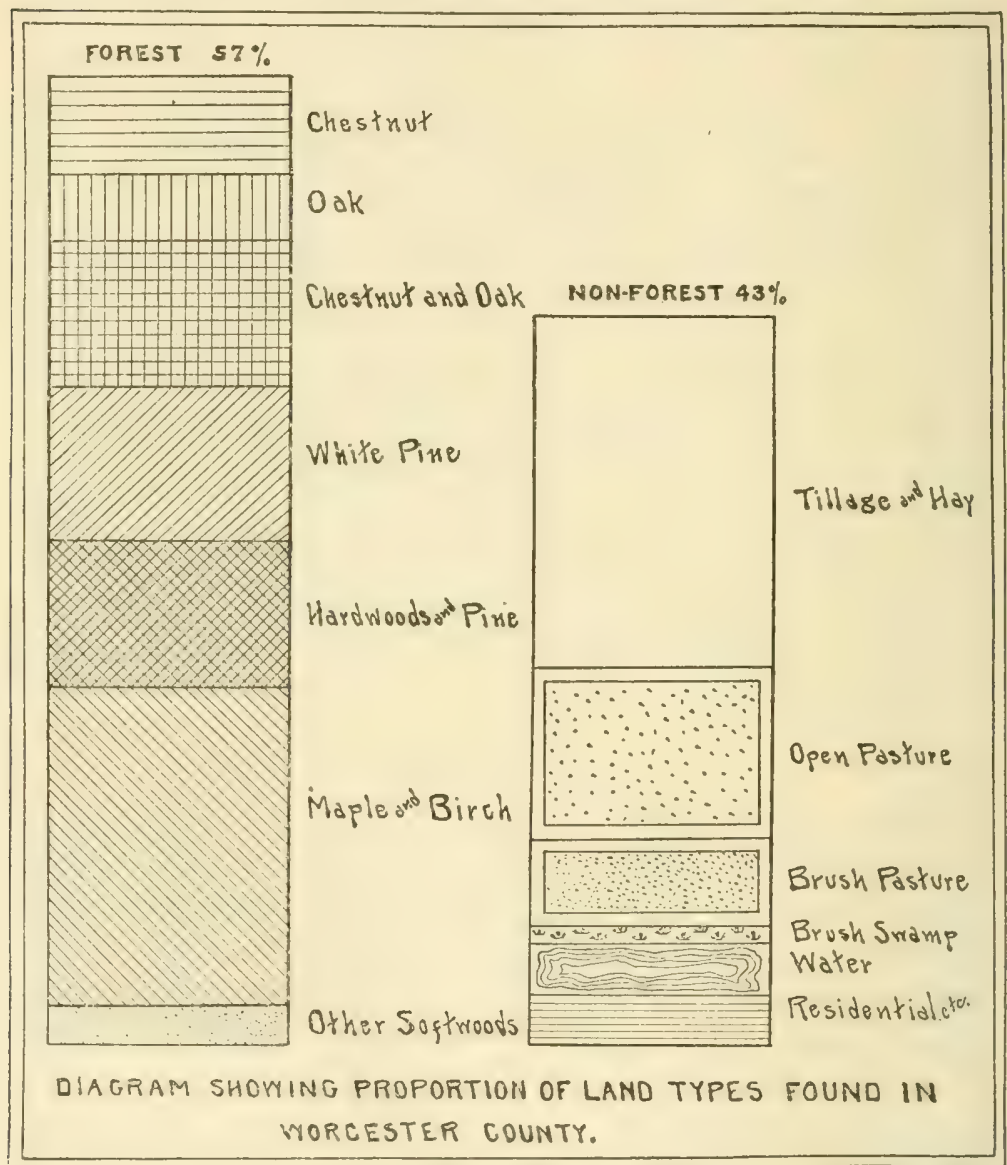

forest area is practically below merchantable size, even for cordwood. This is not to be taken, however, as a discouraging feature, as maturally stands which have reached a merchantable size are soon cut down, and the proportion of the larger sizes must always be low. 
Wood-using Industries.

Worcester County is an important district from the local lumbering standpoint, for of the annual lumber cut in the State, amounting to 400,000,000 feet, it produces at least a third, and of the annual consumption of locally grown lumber used in wood-using industries, amounting to at least 200,000,000 feet, more than one-half is used in this county. The three chief centers for wood-using industries of the State are located in Worcester County; they are Gardner, Winchendon and Athol. The industries using the greatest amount of home-grown timber are those producing boxes, pails, toys, tubs, chairs and match blocks. As the industries of these towns and others are explained in detail in the individual town reports, we will not go further into the matter in this chapter.

Total Land Types.

[59 towns.]

\begin{tabular}{|c|c|c|c|c|c|c|c|c|}
\hline & & \multicolumn{4}{|c|}{ Approximate Size Classies. } & \multirow{2}{*}{ Total. } & \multicolumn{2}{|c|}{ Per Cent. } \\
\hline & & 4 & 3 & 2 & 1 & & Forest. & Town. \\
\hline \multicolumn{2}{|c|}{ Fonest Trpes. } & \multirow{2}{*}{$\begin{array}{r}\text { Acres. } \\
9,059\end{array}$} & Acres. & Acres. & Acres. & \multirow{2}{*}{$\begin{array}{r}\text { Acres. } \\
58,155\end{array}$} & \multirow[b]{2}{*}{10} & \multirow[b]{2}{*}{-} \\
\hline Chestnut, . & $\cdot$ & & 17,965 & 21,150 & $9,9 S 1$ & & & \\
\hline Oak, . . . & $\cdot$ & 14,037 & 16,993 & 6,682 & 2,181 & 39,893 & 7 & - \\
\hline Chestnut and oak, & $\cdot$ & $29,0.49$ & 33,290 & 16,388 & 6,019 & 84,746 & 15 & - \\
\hline White pine, . & - & 13,048 & 28,907 & 29,259 & 21,584 & 92,798 & 16 & - \\
\hline \multicolumn{2}{|c|}{ Hardwoods and white pine, } & 26,086 & 43,320 & 12,918 & 5,454 & 87,778 & 15 & - \\
\hline Maple and birch, & $\cdot \quad \cdot$ & 93,184 & 70,256 & 17,610 & 5,575 & 186,625 & 33 & - \\
\hline $\begin{array}{l}\text { Softwoods other tha } \\
\text { pine. }\end{array}$ & in white & 5,022 & 10,073 & 6,882 & 2,992 & 24,969 & 4 & - \\
\hline Total, & - & 189,485 & 220,804 & 110,889 & 53,786 & 574,964 & - & - \\
\hline Percentage, . & $\cdot \quad \cdot$ & 33 & 39 & 19 & 9 & - & 100 & 57 \\
\hline Tillage and hay, & Non- & FOREST T & YPES. & $\cdot$ & $\cdot$ & 214,450 & - & 21 \\
\hline Open pasture, & - & . & . & . & - & 101,974 & - & 10 \\
\hline Brush pasture, & - & . & . & - & - & 50,109 & - & 5 \\
\hline Alder and brush sw & ramp, & : & - & - & - & 7,461 & - & 1 \\
\hline Business, residentia & al, etc., & . & . & . & - & 25,475 & - & 3 \\
\hline Water, . & - & . & - & - & . & 27,341 & - & 3 \\
\hline Total area of co & ounty, & - & - & - & $\cdot$ & $1,001,774$ & -1 & 100 \\
\hline
\end{tabular}




\section{Ashburnham.}

Pine is fairly abundant in Ashburnham in scattered stands, especially in the south part of the township, and there is considerable reproduction. The greater part of the woodlands is composed of swamp or moisture-liking species, such as spruce, larch, red maple, birch (gray, white and yellow), red oak, poplar and beech. Red maple and beech are particularly abundant, and there are large areas of spruce, larch and hemlock swamp. The mixed hardwood type is composed of red maple, birches, red oak, poplar, beech and a little chestnut, although most of the chestnut has been cut off for the chair factories in Gardner, Winchendon and Ashburnham.

The general size of the timber is in the 3-2 class, the rate of growth is fairly rapid, and the timber is in fair health. On the northwest of Storge Meadow Pond, and also about 1 mile west from Ashburnham Center, are two areas where red pine is abundant in mixture with white pine. Here the red pine is growing about as rapidly as the white pine, and is cleaning itself fairly well, especially where shaded at the side. Reproduction in old pastures is plentiful where white pine stands from which seed has come are near by.

The principal sawmill owners are L. Lashaway, Jr., W. E. Jefts, Warren Marble, Charles Russell and W. E. Peckens. L. Lashaway cuts pine, spruce and hemlock, about 1,000,000 board feet per year. The other owners saw irregularly, but probably each saws from 500,000 to $1,000,000$ board feet per year. In addition there are many portable mill operators who come in from other towns.

The W. F. Whitney Company, in South Ashburnham, has two mills, using mostly southern oak and a little birch, bech and maple from New Hampshire and Vermont.

The Curtis chair shop at Ashburnham uses per year 120,000 board feet of chestnut and 132,000 of birch, beech and maple, practically all of which comes from outside the State.

Wright's crutch factory turns out 3,500 crutches per month, and uses the following:- 
Rock maple, $1 \frac{1}{8}$ inch, $100 \mathrm{M}$ board feet per annum.

Rock maple, $1 \frac{1}{4}$ inch, 6 to $8 \mathrm{M}$ board feet per annum.

Birch, $1 \frac{1}{4}$ inch, $10 \mathrm{M}$ board feet per annum.

Rosewood, 300 board feet per annum.

Cherry, 5 to $6 \mathrm{M}$ board feet per annum.

Land Types.

\begin{tabular}{|c|c|c|c|c|c|c|c|}
\hline & \multicolumn{4}{|c|}{ Approximate Size Classes. } & \multirow{2}{*}{ Total. } & \multicolumn{2}{|c|}{ Per Cent. } \\
\hline & 4 & 3 & 2 & 1 & & Forest. & Town. \\
\hline Fonest TrPes. & Acres. & Acres. & Acres. & Acres. & Acres. & & \\
\hline Chestnut, . . . & 91 & - & 97 & - & 188 & 1 & - \\
\hline Oak, . . . & 195 & 273 & 234 & 143 & 845 & 4 & - \\
\hline Chestnut and oak, . . & 58 & 39 & 169 & 150 & 416 & 2 & - \\
\hline White pine, . . & 318 & 937 & 1,201 & 3,368 & 5,824 & 31 & - \\
\hline Hardwoods and white pine, 1 & 726 & 779 & 189 & 336 & 2,030 & 11 & - \\
\hline Maple and gray birch, & 2,564 & 2,012 & 356 & 785 & 5,717 & 31 & - \\
\hline $\begin{array}{l}\text { Softwoods other than white } \\
\text { pine. }{ }^{2}\end{array}$ & 617 & 1,525 & 941 & 643 & 3,726 & 20 & - \\
\hline Total, . . & 4,569 & 5,565 & 3,187 & 5,425 & 18,746 & -1 & - \\
\hline Percentage, . & 24 & 30 & 17 & 29 & - & 100 & 71 \\
\hline Tillage and hay, . NoN-1 & FOREST T & YPES. & • & $\cdot$ & 3,173 & -1 & 12 \\
\hline Open pasture, & . & . & . & . & 2,745 & - & 10 \\
\hline Brush pasture, . & . & . & . & . & 513 & - & 2 \\
\hline Business, residential, etc., & . & . & . & . & 324 & - & 1 \\
\hline Water, - . . . & . & . & - & . & 1,123 & - & 4 \\
\hline Total area of town, . & . & . & . & . & 26,624 & -1 & 100 \\
\hline
\end{tabular}

1 Hardwoods are mostly gray birch and maple with some white birch, poplar and beech.

2 Swamp spruce with a little larch and hemlock. Very little pitch pine.

\section{AтHоL.}

The northern portion of the town is a natural white pine region. White pine is the principal growth, with chestnut, oak, birch and maple coming next in order. The largest stand of white pine noted was possibly 150 acres in area, while the average stand was about 30 acres. In some places red pine was found in mixture with the white pine, and for the same period of years the red pine seems to have outgrown the white pine 
in volume. The southern part of the town is more of a hardwoods region. Ilere the main growth is chestnut and oak, with white pine, birch and maple coming next in order named. Occasionally small stands of pure hemlock were found. The hardwoods, chestnut and oak, were found in both pure and mixed stands. In the mixed hardwoods, suppressed pine was found but very rarely. Small areas of gray birch and white pine were found in mixture.

Athol has one sawmill and several wood-using industries. A sawmill situated in Athol and owned by Fred Patenaude cuts 8,000 board feet per day of white pine for local use.

Athol Center has several wood-using industries, as follows: (1) Diamond Match Company, which consumed 19,000,000 board feet of white pine in 1912 and 13,000,000 in 1913; this was used for match blocks; 3,000,000 came from Maine, 1,000,000 from Connecticut, while the balance was divided between Massachusetts and New Hampshire. (2) N. D. Cass Company use 1,500,000 of white pine, chestnut and hemlock in the manufacture of wooden toys. (3) Stratton Bros \& Co., manufacturers of boxes and interior house finishings, use 500,000 board feet of white pine and southern yellow pine; the yellow pine amounting to 80,000 board feet. (4) A. J. Raymond consumes 2,000,000 board feet of white and hard pine and a small proportion of cypress in the manufacture of sash, doors and blinds; this comes from California, Oregon, Michigan, Maine, New Hampshire and Massachusetts. (5) A. T. Tyler Company, product, sash and blinds, use 1,000,000 to $1,500,000$ board feet of white pine, coming from New York and Michigan, and about 100,000 feet of sugar pine, coming from California. (6) L. Morse \& Sons manufacture furniture from white pine, oak and chestnut received from local parties. (7) H. M. Peckham supplies local demands with rails, posts and balustrades. 
Land Types.

\begin{tabular}{|c|c|c|c|c|c|c|c|c|}
\hline & & \multicolumn{4}{|c|}{ Approximate Size Classes. } & \multirow{2}{*}{ Total. } & \multicolumn{2}{|c|}{ Per Cent. } \\
\hline & & 4 & 3 & 2 & 1 & & Forest. & Town. \\
\hline \multicolumn{2}{|c|}{ Forest Types. } & Acres. & Acres. & Acres. & Acres. & Acres. & & \\
\hline Chestnut, . & . & 296 & 255 & 497 & 128 & 1,176 & 7 & - \\
\hline Oak, . . & . & 336 & 242 & 222 & - & 800 & 5 & - \\
\hline Chestnut and oak, & . & 988 & 967. & 537 & 134 & 2,626 & 16 & - \\
\hline White pine, & . & 370 & 672 & 1,048 & 766 & 2,856 & 18 & - \\
\hline \multicolumn{2}{|c|}{ Hardwoods and white pine, 1} & 1,182 & 1,538 & 1,303 & 262 & 4,285 & 26 & - \\
\hline \multirow{2}{*}{\multicolumn{2}{|c|}{$\begin{array}{l}\text { Maple and gray birch, } \\
\text { Softwoods other than white } \\
\text { pine. }{ }^{2}\end{array}$}} & 2,553 & 1,350 & 322 & 74 & 4,299 & 26 & - \\
\hline & & 20 & 148 & 168 & 20 & 356 & 2 & - \\
\hline Total, . & . & 5,745 & 5,172 & 4,097 & 1,384 & 16,398 & - & - \\
\hline Percentage, . & $\cdot$ & 35 & 32 & 25 & 8 & \multirow[b]{2}{*}{2,298} & 100 & \multirow[t]{2}{*}{75} \\
\hline \multicolumn{6}{|c|}{ NoN-FOREST TrPEs. } & & \multirow{2}{*}{-} & \\
\hline Open pasture, & . & . & . & . & - & 1,794 & & 8 \\
\hline Brush pasture, & . & - & . & - & $\cdot$ & - 262 & - & 1 \\
\hline Business, residentia & al, etc., & - & . & - & . & 894 & - & 4 \\
\hline Water, . & . & - & . & . & . & 370 & - & 2 \\
\hline Total area of to & own, . & . & . & . & - & 22,016 & - & 100 \\
\hline
\end{tabular}

1 Hardwoods are largely birch and maple, with some oak and chestnut in the Iarger sizes.

2 Mostly hemlock and spruce.

\section{AUBURN.}

Chestnut is the chief tree of the town, the chestnut and oak type seeming to predominate. Most of it is still unmerchantable save for cordwood, and a good deal has been cut over within the last ten years. Clear cutting is the rule, with a little poor selection cutting which leaves thin, scraggly stands. There are a few small stands of merchantable pine, notably Prospect Park, just south of Stoneville. There is a good stand of small merchantable chestnut and some pine about a mile southeast of the center of the town. There is quite a little maple swamp, and in places small stands of pitch pine.

No sawmills nor woodworking industries were found in the town. A mill belonging to Geo. L. Jacques of Worcester had recently cut off the southeast slope of Prospect Hill, where there was a stand of small chestnut, oak and some pine. 
Land Types.

\begin{tabular}{|c|c|c|c|c|c|c|c|c|c|}
\hline & & & \multicolumn{4}{|c|}{ Approximate Size Classes. } & \multirow{2}{*}{ Total. } & \multicolumn{2}{|c|}{ Per Cent. } \\
\hline & & & 4 & 3 & 2 & 1 & & Forest. & Town. \\
\hline \multicolumn{3}{|c|}{ Forest Types. } & Acres. & Acres. & Acres. & Acres. & Acres. & & \\
\hline Chestnut, . & . & . & 220 & 140 & 180 & 70 & 610 & 14 & - \\
\hline Oak, . . . & . & . & 60 & 50 & 40 & 20 & 170 & 4 & - \\
\hline Chestnut and oak & , . & . & 600 & 360 & 60 & 30 & 1,050 & 24 & - \\
\hline White pine, & . & . & - & 160 & 80 & 40 & 280 & 6 & - \\
\hline \multicolumn{3}{|c|}{ Hardwoods and white pine, 1} & 130 & 340 & 40 & - & 510 & 12 & - \\
\hline \multirow{2}{*}{\multicolumn{3}{|c|}{$\begin{array}{l}\text { Maple and gray birch, } \\
\text { Softwoods other than white } \\
\text { pine.2 }\end{array}$}} & 780 & 710 & 100 & 50 & 1,640 & 37 & - \\
\hline & & & 90 & - & 70 & - & 160 & 3 & - \\
\hline Total, . . & - & - & 1,880 & 1,760 & 570 & 210 & 4,420 & - & - \\
\hline Percentage, & - & $\cdot$ & 43 & 40 & 13 & 4 & - & 100 & 49 \\
\hline \multicolumn{7}{|c|}{ NoN-Forest TYPES. } & 2,960 & - & 33 \\
\hline Open pasture, & $\cdot$ & . & - & . & . & - & 820 & - & 9 \\
\hline Brush pasture, & . & - & - & . & . & - & 390 & - & 4 \\
\hline Water, . & . & . & . & . & . & . & 460 & - & 5 \\
\hline \multicolumn{3}{|c|}{ Total area of town, . } & . & . & . & $\cdot$ & 9,050 & - & 100 \\
\hline
\end{tabular}

1 Hardwoods are mostly gray birch and poplar.

2 Mostly pitch pine with some cedar.

\section{BARRE.}

Although this town has been extensively logged, there is still a large amount of growing pine left, amounting to 50 per cent. of the forest area. There is very little, however, of commercial size. Commercially speaking, chestnut follows pine in importance, but occurs with far less frequency. Red maple and birch form one-fifth of the forest area.

Most of the lumber cut in Barre has been shipped outside. There is a sash and blind factory at Barre Plains belonging to Mr. T. E. Rich, and a planing mill owned by H. A. Knight. James A. Rice is the leading operator. 
Land Types.

\begin{tabular}{|c|c|c|c|c|c|c|c|c|}
\hline & & \multicolumn{4}{|c|}{ Approximate Size Classes. } & \multirow{2}{*}{ Total. } & \multicolumn{2}{|c|}{ Per Cent. } \\
\hline & & 4 & 3 & 2 & 1 & & Forest. & Town. \\
\hline \multicolumn{2}{|c|}{ Forest Types. } & Acres. & Acres. & Acres. & Acres. & Acres. & & \\
\hline Chestnut, . & . $\quad$. & - & 67 & 393 & 193 & 653 & 4 & - \\
\hline $\mathrm{Oak}$ &.$\quad$. & - & 121 & 48 & 48 & 217 & 1 & - \\
\hline Chestnut and oak, & $\cdot \quad \cdot$ & 490 & 858 & 417 & 42 & 1,807 & 12 & - \\
\hline White pine, & . & 459 & 2,213 & 1,415 & 744 & 4,831 & 32 & - \\
\hline \multicolumn{2}{|c|}{ Hard woods and white pine, 1} & 889 & 3,059 & 314 & 48 & 4,310 & 29 & - \\
\hline \multirow{2}{*}{\multicolumn{2}{|c|}{$\begin{array}{l}\text { Maple and gray birch, } \\
\text { Softwoods other than white } \\
\text { pine. }\end{array}$}} & 2,080 & 883 & 151 & 12 & 3,126 & 21 & - \\
\hline & & - & 24 & 79 & 85 & 188 & 1 & - \\
\hline Total, & $\cdot$ & 3,918 & 7,225 & 2,817 & 1,172 & 15,132 & - & - \\
\hline Percentage, . & . & 26 & 48 & 18 & 8 & - & 100 & 52 \\
\hline \multicolumn{6}{|c|}{ Tillage and hay, . NON-FOREST TrPes. } & 6,922 & - & 24 \\
\hline Open pasture, & . & . & . & . & . & 6,402 & - & 22 \\
\hline Brush pasture, & - & . & - & - & - & 393 & - & 1 \\
\hline \multicolumn{2}{|c|}{ Business, residential, etc., } & . & . & - & . & 248 & \multirow{2}{*}{ - } & \multirow{2}{*}{1} \\
\hline Water, . . & . & - & - & - & - & 151 & & \\
\hline \multicolumn{2}{|c|}{ Total area of town, . } & - & - & . & $\cdot$ & 29,248 & - & 100 \\
\hline
\end{tabular}

\&ardwoods are gray birch, maple and poplar in smaller sizes, giving way to chestnut and oak in larger sizes.

\section{BERLIN.}

The proportion of timbered land to the total area of the town is about 50 per cent. The predominating type is oak and pine, usually in mixed stands. Chestnut exists in pure stands and in mixed stands with oak and pine. Hickory is more common than in the average town, but there are no absolutely pure stands.

Edmund W. Wheeler of South Berlin operates a sawmill cutting about $250 \mathrm{M}$ board feet per year. He uses mostly pine, chestnut and oak. W. A. Wheeler of Berlin cuts chestnut poles and ties. 
Land Types.

\begin{tabular}{|c|c|c|c|c|c|c|c|c|c|}
\hline & & & \multicolumn{4}{|c|}{ Approximate Size Classes. } & \multirow{2}{*}{ Total. } & \multicolumn{2}{|c|}{ Per Cent. } \\
\hline & & & 4 & 3 & 2 & 1 & & Forest. & Town. \\
\hline \multicolumn{3}{|c|}{ Forest Trpes. } & Acres. & Acres. & Acres. & Acres. & Acres. & & \\
\hline Chestnut, . & & & 70 & 170 & 140 & 280 & 660 & 16 & - \\
\hline Oak, . . & - & . & 140 & 820 & 260 & 70 & 1,290 & 31 & - \\
\hline Chestnut and oal & , & $\cdot$ & 70 & 170 & 130 & 70 & 440 & 10 & - \\
\hline White pine, & . & . & 30 & 70 & 160 & 160 & 420 & 10 & - \\
\hline \multicolumn{3}{|c|}{ White pine and hardwoods, 1} & 40 & 320 & 110 & 60 & 530 & 13 & - \\
\hline \multirow{2}{*}{\multicolumn{3}{|c|}{$\begin{array}{l}\text { Maple and gray birch, } \\
\text { Softwoods other than white } \\
\text { pine. }\end{array}$}} & 230 & 500 & 30 & 40 & 800 & 19 & - \\
\hline & & & - & 30 & 30 & 10 & 70 & 1 & - \\
\hline Total, . & & . & 580 & 2,080 & 860 & 690 & 4,210 & - & - \\
\hline Percentage, . & • & . & 14 & 49 & 20 & 17 & - & 100 & 50 \\
\hline \multicolumn{7}{|c|}{ NON-FOREST TYPES. } & 2,820 & - & 33 \\
\hline Open pasture, & . & - & - & - & . & - & 560 & - & 7 \\
\hline Brush pasture, & . & . & . & - & . & - & 740 & - & 9 \\
\hline Water, . & $\cdot$ & • & . & - & . & $\cdot$ & 110 & - & 1 \\
\hline \multicolumn{3}{|c|}{ Total area of town, . } & . & . & . & - & 8,440 & - & 100 \\
\hline
\end{tabular}

1 Hardwoods are principally birch, maple and oak.

2 Pitch pine and hemlock.

\section{BLACKSTONE.}

The wooded section of Blackstone is in poor condition as regards thriftiness and percentage of useful species, on account of the severe fires which have swept through. There is almost no timber left which is merchantable, and very little which will grade above a straight Class 3. Pine and softwoods are lacking, even in reproduction, partly because of their greater susceptibility to fire, which makes for a higher percentage of hardwoods wherever it gets in. There are scattered small lots of pine in the northern part of the town and on Candlewood Iill, but the greater part of the land is covered with a sprout growth of oaks, gray birch, chestnut and red maple.

There were no portable mills working in the town at the time the survey was made. Moreover, there is only one permanent mill. This mill is located in East Blackstone, being 
run by water power from the Mill River. Mr. A. S. Kelley is the owner. This mill is a small one, the amount cut varying, but seldom exceeding $50 \mathrm{M}$ board feet annually. The stock is mostly chestnut, with some pine.

Land Types.

\begin{tabular}{|c|c|c|c|c|c|c|c|c|c|}
\hline & & & \multicolumn{4}{|c|}{ Approximate Size Classes. } & \multirow{2}{*}{ Total. } & \multicolumn{2}{|c|}{ Per Cent. } \\
\hline & & & 4 & 3 & 2 & 1 & & Forest. & Town. \\
\hline \multicolumn{3}{|c|}{ Forest TyPes. } & Acres. & Acres. & Acres. & Acres. & Aeres. & & \\
\hline Chestnut, . & & & 118 & 243 & 76 & - & 437 & 7 & - \\
\hline Oak, . & &. & 186 & 274 & 15 & 22 & 497 & 8 & - \\
\hline Chestnut and oak & $\therefore$ & $\cdot$ & 63 & 871 & 278 & 54 & 1,266 & 19 & - \\
\hline White pine, & - & $\cdot$ & 55 & 27 & 34 & 102 & 218 & 3 & - \\
\hline \multicolumn{3}{|c|}{ Hardwoods and white pine, 1} & 307 & 452 & 157 & 41 & 957 & 14 & - \\
\hline \multirow{2}{*}{\multicolumn{3}{|c|}{$\begin{array}{l}\text { Maple and gray birch, } \\
\text { Softwoods other than white } \\
\text { pine. }\end{array}$}} & 985 & 572 & 181 & 51 & 1,789 & 27 & - \\
\hline & & & 446 & 536 & 296 & 166 & 1,444 & 22 & - \\
\hline Total, . & - & $\cdot$ & 2,160 & 2,975 & 1,037 & 436 & 6,608 & -1 & - \\
\hline Percentage, . & - & $\cdot$ & 33 & 45 & 15 & 7 & - & 100 & 64 \\
\hline \multicolumn{7}{|c|}{ Tillage and hay, Non-Forest TYPES. } & 2,054 & - & 20 \\
\hline Open pasture, & - & - & . & . & . & . & 363 & - & 3 \\
\hline Brush pasture, & - & - & - & - & - & - & 1,184 & -1 & 11 \\
\hline Water, & - & - & . & - & - & - & 197 & - & 2 \\
\hline \multicolumn{3}{|c|}{ Total area of town,. } & - & - & . & $\cdot$ & 10,406 & - & 100 \\
\hline
\end{tabular}

1 Hardwoods consist of maple, chestnut and oak.

2 Largely pitch pine with some cedar.

Bolton.

The general condition of the forest is good, especially in the pine, oak and hardwood types. There is a good layer of humus. The principal species are pine and chestnut and oak in clear and mixed stands. Ash and hickory are common in the mixture and also as roadside trees. Suppressed pine is common in the chestnut and oak types. The Century Mill, W. J. Webber, proprietor, cuts chestnut and pine to the extent of about $75 \mathrm{M}$ board feet per year. This is the only lumber mill in Bolton, and it is idle most of the time. 
Land Types.

\begin{tabular}{|c|c|c|c|c|c|c|c|c|c|}
\hline & & & \multicolumn{4}{|c|}{ Approximate Size Classes. } & \multirow{2}{*}{ Total. } & \multicolumn{2}{|c|}{ Per Cent. } \\
\hline & & & 4 & 3 & 2 & 1 & & Forest. & Town. \\
\hline \multicolumn{3}{|c|}{ Forest TrPes. } & Acres. & Acres. & Acres. & Acres. & Acres. & & \\
\hline Chestnut, . & & . & 128 & 527 & 383 & 55 & 1,093 & 17 & - \\
\hline Oak, . & & - & 150 & 419 & 155 & 153 & 877 & 13 & - \\
\hline \multicolumn{2}{|l|}{ Chestnut and oak, } & . & 424 & 887 & 255 & 230 & 1,796 & 28 & - \\
\hline White pine, & & - & 20 & 424 & 166 & 361 & 971 & 15 & - \\
\hline \multicolumn{3}{|c|}{ Hardwoods and white pine, 1} & 100 & 349 & 50 & 72 & 571 & 9 & - \\
\hline \multicolumn{3}{|c|}{ Maple and gray birch, } & 132 & 780 & 164 & - & 1,076 & 16 & - \\
\hline \multicolumn{3}{|c|}{$\begin{array}{l}\text { Softwoods other than white } \\
\text { pine. }{ }^{2}\end{array}$} & - & 112 & 35 & 9 & 156 & 2 & - \\
\hline Total, . & & - & 954 & 3,498 & 1,208 & 880 & 6,540 & - & - \\
\hline Percentage, . & & - & 14 & 53 & 19 & 14 & - & 100 & 51 \\
\hline \multicolumn{7}{|c|}{ NON-FOREST TYPES. } & 4,373 & - & 34 \\
\hline Open pasture, & . & . & . & . & - & . & 902 & - & 7 \\
\hline Brush pasture, & - & - & . & - & . & - & 945 & - & 7 \\
\hline Water, . & - & - & * & . & . & $\cdot$ & 30 & - & 1 \\
\hline \multicolumn{3}{|c|}{ Total area of town, . } & - & . & $\cdot$ & - & 12,790 & - & 100 \\
\hline
\end{tabular}

1 Principally maple and birch.

2 Pitch pine.

\section{BOYLSTON.}

The proportion of wooded land to the total area of the town is about 50 per cent. The chief types are chestnut, oak, pine and soft maple, in clear and mixed stands. In general the condition is healthy. Practically all of the pine plantations around the shores of the reservoir show a healthy growth.

The Sterling Lumber Company, represented by Walker, Wilding \& Davis, a Worcester firm, transact most of the lumber business of this town, and cut about $200 \mathrm{M}$ feet per year.

George F. Flagg, Boylston Center, does some lumbering and cuts about $200 \mathrm{M}$ feet per year. 
Land Types.

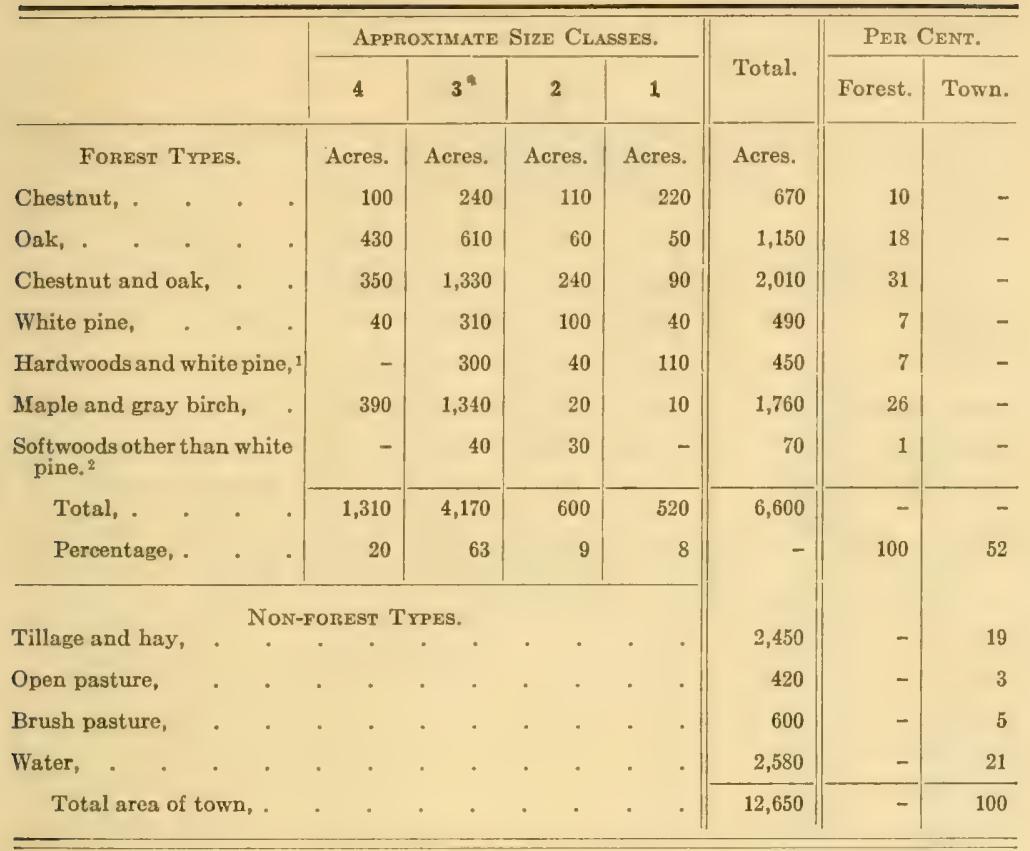

1 Hardwoods are mostly maple, with some chestnut, oak and gray birch.

2 Pitch pine.

\section{BROOKFIELD.}

The woodlands are practically a mixture of all kinds of hardwoods. The stands are all second growth in origin. The woods were cut many years ago when the railroads were using wood for fuel. These grew up and in many cases were cut again within the last twenty or twenty-five years. Chestnut is not abundant. There are a few pure stands, but as a rule it occurs chiefly as a part of a mixture. This mixture is mostly maple, gray birch, oak and chestnut, with an occasional cherry. The stands are very irregular, the type constantly changing so that the term "mixed hardwoods" is the best one to apply. White pine is an important factor in nearly all the stands. In many cases the type could be changed to a pure pine type with good stocking if the inferior species were eliminated. 
There are no sawmills in the town, but the cutting is done chiefly by William F. Fullam and H. E. Cummings of North Brookfield.

Land Types.

\begin{tabular}{|c|c|c|c|c|c|c|c|c|}
\hline & & \multicolumn{4}{|c|}{ Approximate Size Classes. } & \multirow{2}{*}{ Total. } & \multicolumn{2}{|c|}{ Per Cent. } \\
\hline & & 4 & 3 & 2 & 1 & & Forest. & Town. \\
\hline \multicolumn{2}{|c|}{ Forest Types. } & Acres. & Acres. & Acres. & Acres. & Acres. & & \\
\hline Chestnut, . & . & 460 & 600 & 410 & 30 & 1,500 & 14 & $\cdot$ \\
\hline Oak, . . . & - & - & - & 100 & - & 100 & 1 & - \\
\hline Chestnut and oak & , . & 120 & 20 & 80 & 350 & 570 & 5 & - \\
\hline White pine, & - & 80 & 270 & 100 & 70 & 520 & 5 & - \\
\hline \multicolumn{2}{|c|}{ Hardwoods and white pine, 1} & 500 & 1,200 & 1,650 & 110 & 3,460 & 33 & - \\
\hline \multicolumn{2}{|c|}{ Maple and gray birch, } & 470 & 1,160 & 2,300 & 420 & 4,350 & 42 & - \\
\hline Total, . & - & 1,630 & 3,250 & 4,640 & 980 & 10,500 & -1 & - \\
\hline Percentage, . & - & 16 & 31 & 44 & 9 & - & 100 & 59 \\
\hline \multicolumn{6}{|c|}{ NON-FOREST TYPES. } & 2,810 & - & 14 \\
\hline Open pasture, & . & . & . & . & . & 1,650 & - & 9 \\
\hline Brush pasture, & . & . & . & . & $\cdot$ & 480 & - & 3 \\
\hline Brush swamp, & - & . & . & . & $\cdot$ & 1,110 & - & 6 \\
\hline \multicolumn{2}{|c|}{ Business, residential, etc., } & . & . & . & - & 140 & - & 1 \\
\hline Water, . & . & - & - & . & - & 1,010 & - & 6 \\
\hline \multicolumn{2}{|c|}{ Total area of town,. } & - & . & . & $\cdot$ & 17,700 & - & 100 \\
\hline
\end{tabular}

1 Hardwoods are largely maple and birch, with some chestnut and oak.

\section{Charlton.}

The maple and birch type predominates, mostly in small sizes. Following this type in order of importance come the chestnut and oak type, the hardwoods and white pine type, and the white pire type. Few pure stands of chestnut exist. The same holds true of oak. The only type running into the Class 1 size that was noted was that of the white pine.

There are two combined sawmills and box shops capable of cutting from 300 to 500 M board feet per annum. That of Marcus Carpenter is located in Charlton City, while the Putnam Brothers' mill is situated in the eastern part of the 
town about $1 \frac{1}{2}$ miles from Richardson's Corner. Both obtain their logs locally, and sell their products either in Charlton or in Worcester.

Land T'ypes.

\begin{tabular}{|c|c|c|c|c|c|c|c|}
\hline & \multicolumn{4}{|c|}{ Approximate Size Classes. } & \multirow{2}{*}{ Total. } & \multicolumn{2}{|c|}{ Per Cent. } \\
\hline & 4 & 3 & 2 & 1 & & Forest. & Town. \\
\hline FOREST TYPES. & Acres. & Acres. & Acres. & Acres. & Acres. & & \\
\hline Chestnut, . & 30 & 120 & 160 & - & 310 & 2 & - \\
\hline Oak, . . . . & 50 & 180 & 20 & - & 250 & 2 & - \\
\hline Chestnut and oak, . & 1,270 & 1,650 & 110 & - & 3,030 & 22 & - \\
\hline White pine, & 150 & 800 & 1,000 & 80 & 2,030 & 15 & - \\
\hline Hardwoods and white pine, & 890 & 1,660 & 160 & - & 2,710 & 20 & - \\
\hline Maple and birch, . & - 3,700 & 1,720 & 30 & - & 5,450 & 39 & - \\
\hline Hemlock, . . & - & 40 & 10 & - & 50 & 39 & - \\
\hline Total, . & 6,090 & 6,170 & 1,490 & 80 & 13,830 & - & - \\
\hline Percentage, . & 44 & 44 & 11 & 1 & - & 100 & 49 \\
\hline Tillage and hay, . NoN & FOREST T & YPES. & $\cdot$ & . & 7,240 & - & 26 \\
\hline Open pasture, & . & . & . & $\cdot$ & 3,130 & - & 11 \\
\hline Brush pasture, & . & . & . & $\cdot$ & 2,520 & - & 9 \\
\hline Alder swamp, & $\cdot$ & . & . & . & 410 & - & 1 \\
\hline Business, residential, etc., & . & · & . & . & 150 & - & 1 \\
\hline Water, . . & . & - & . & . & 850 & - & 3 \\
\hline Total area of town, . & . & . & . & . & - & - & 100 \\
\hline
\end{tabular}

\section{Clinton.}

The proportion of forest to cleared land is about 40 per cent. The principal types are pine, oak and chestnut in mixed stands, very little being of timber size. The entire northeast corner is sprout land, sizes 3 and 4. Merchantable timber is found in very small isolated wood lots. The general condition is only fair.

W. A. Fuller cuts pine, chestnut, oak and pitch pine; amount per year about $1,400 \mathrm{M}$.

W. L. Bancroft cuts pine, chestnut and oak; amount per year a little less than $1,000,000$ feet. 
Phillip Philburn cuts 250 M per year, - pine 200 M, chestnut $50 \mathrm{M}$, and 1,500 cords of wood.

Bennett Alder cuts cordwood only, - chestnut, oak and pine mostly, in Clinton, Boylston and Bolton.

Land Types.

\begin{tabular}{|c|c|c|c|c|c|c|c|c|}
\hline & & \multicolumn{4}{|c|}{ Approximate Size Classses. } & \multirow{2}{*}{ Total. } & \multicolumn{2}{|c|}{ Per Cent. } \\
\hline & & 4 & 3 & 2 & 1 & & Forest. & Town. \\
\hline \multicolumn{2}{|c|}{ Forest Trpes. } & Acres. & Acres. & Acres. & Acres. & Acres. & & \\
\hline Chestnut, . & . & - & 120 & 30 & 90 & 240 & 14 & - \\
\hline Oak, . . & - & 340 & 380 & 60 & 20 & 800 & 47 & - \\
\hline Chestnut and oak & - & - & 280 & 60 & 60 & 400 & 23 & - \\
\hline White pine, & $\cdot$ & 20 & 40 & 20 & 10 & 90 & 5 & - \\
\hline Hardwoods and w & ite pine, ${ }^{1}$ & - & 10 & - & - & 10 & 1 & - \\
\hline Maple and gray b & reh, & 40 & 50 & - & - & 90 & 5 & - \\
\hline Pitch pine, & $\cdot$ & - & - & 90 & - & 90 & 5 & - \\
\hline Total, . & $\cdot$ & 400 & 880 & 260 & 180 & 1,720 & - & - \\
\hline Percentage, . & . & 23 & 51 & 15 & 11 & - & 100 & 37 \\
\hline \multicolumn{6}{|c|}{ NoN-FOREST TYPES. } & 650 & - & 14 \\
\hline Open pasture, & . & - & . & . & . & 80 & - & 2 \\
\hline Brush pasture, & . & . & . & . & . & 30 & - & 28 \\
\hline Business, resident & al, etc., & . & - & . & . & 1,290 & & \\
\hline Water, . . & . & . & - & . & . & 860 & - & 19 \\
\hline Total area of & own, . & . & . & . & - & 4,620 & - & 100 \\
\hline
\end{tabular}

1 Hardwood is principally gray birch.

DANA.

Over two-thirds of the town is in forest, and white pine types predominate. There is a considerable amount of pine of commercial size, but it is being rapidly logged at this time. Oak is widespread, but usually in mixed stands.

The chief industry at North Dana is a hat factory, but woodusing industries occupy a considerable place. There is a box factory in North Dana belonging to Grover and Gee, and also one at Soapstone now operated by a Mr. Donnell. Principal wood-lot operators are C. E. Gee, Cleveland Grover, R. N. Doubleday and Otis Hager. The F. M. West Box Company of Springfield have large holdings of pine timber in Dana. 
Land Types.

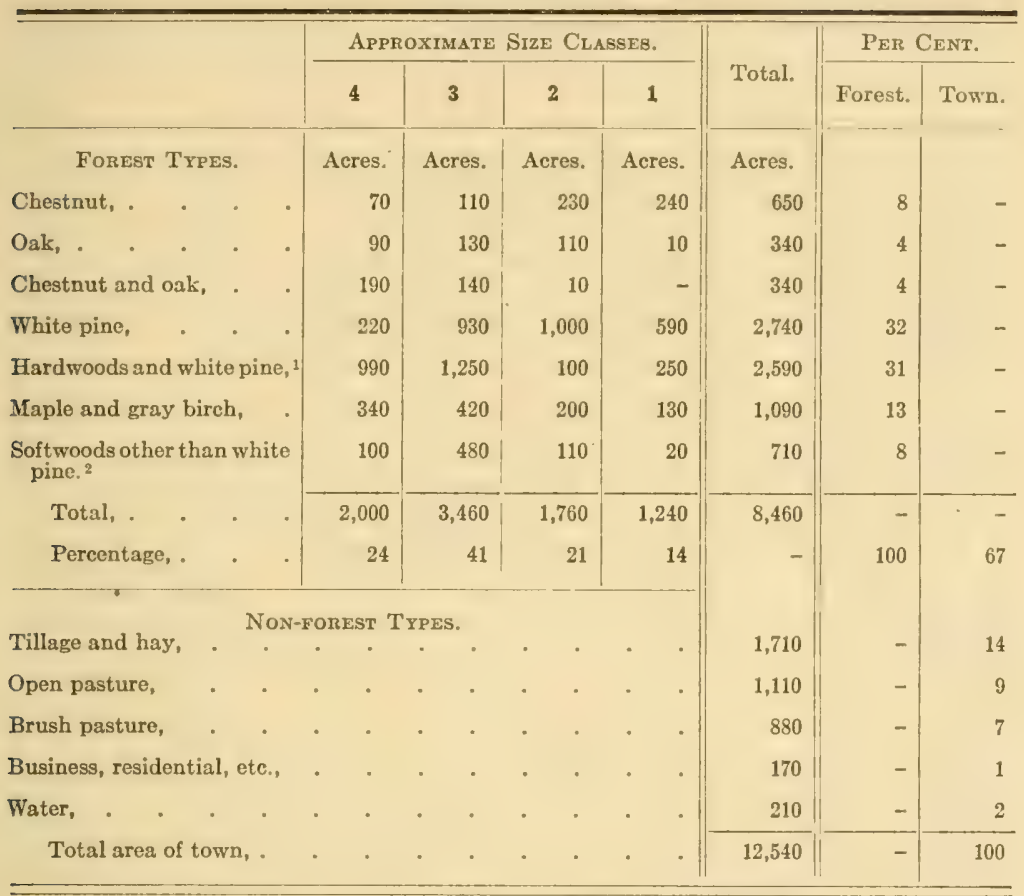

1 Hardwoods consist of gray birch, maple and oaks.

${ }^{2}$ About one-half pitch pine and one-half hemlock.

\section{Douglas.}

The town is about 85 per cent. wooded. This wooded area contains mostly a dense healthy growth of white pine, pitch pine, oak, chestnut and hardwoods, varying in size from 4 to 1 . There is a considerable amount of swamp in town containing some hemlock and cedar.

There are two sawmills in the town; that of Mr. W. R. Wallis saws about $500 \mathrm{M}$ feet of pine and chestnut per year, while that of Charles Church, running about half the time, cuts about $200 \mathrm{M}$ board feet of chestnut and pine per year. Mr. W. R. Wallis also owns a box factory which, in connection with his mill, uses about 1,000,000 feet of pine, oak, chestnut, spruce and cedar. Mr. R. E. Dudley operates a portable mill during the fall and winter months. He cuts about 1,000,000 feet per year of pine, oak and chestnut. 
Land Types.

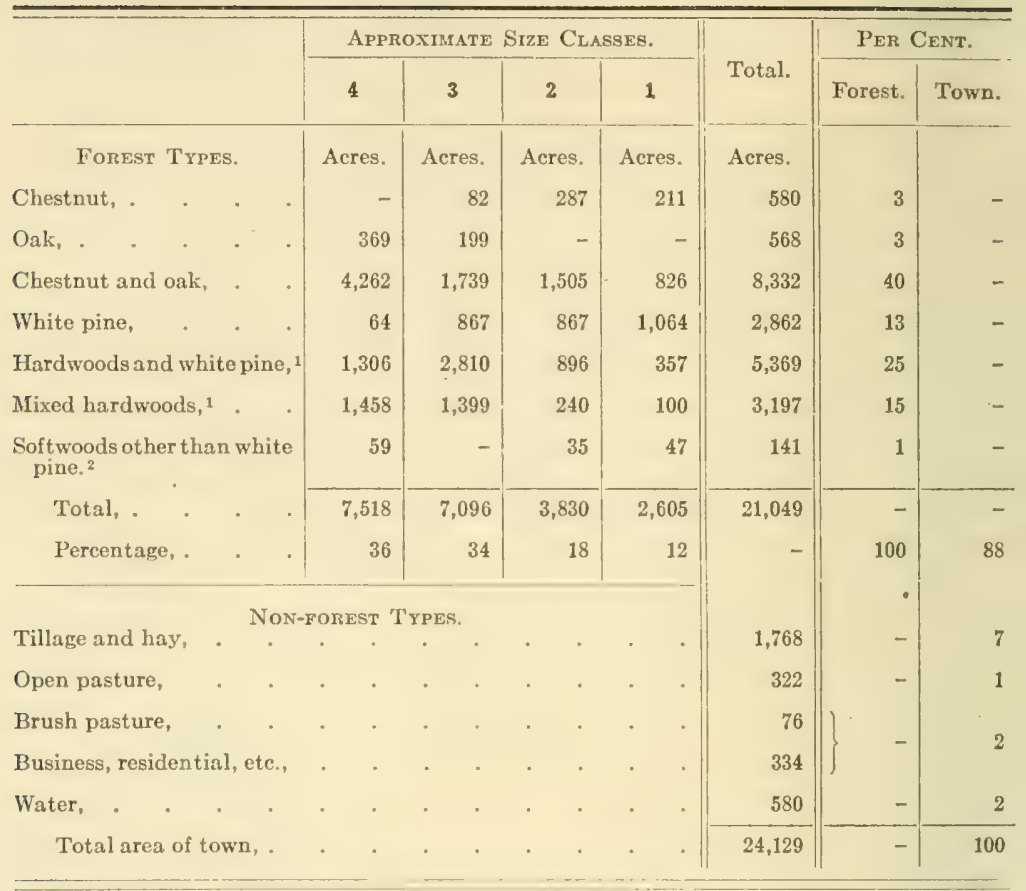

1 Hardwoods are maple, oak, chestnut and gray birch.

2 Cedar and hemlock.

\section{DUDLEY.}

In Dudley the timber is confined to several distinct areas. Along the western boundary and in for about three-quarters of a mile it forms an almost solid belt. From this line over to the lake region the town is given over almost entirely to agriculture, and outside of small patches of mixed hardwoods of unmerchantable size very little hardwood occurs. A longitudinal strip, comprising the eastern quarter of the town, is covered with some excellent stands of chestnut.

The prevailing types are chestnut, chestnut and oak, mixed hardwoods and birch, while in some places pine occurs, usually in combination with one of the above-named types. In no place was found a stand which could be classified as large merchantable. The chestnut along the western and eastern parts runs close to Class 2, but it will be some time before the 
bulk will reach this size. The majority of the best trees now run in a large 3 to a small 2 class. The chestnut stands in the eastern part of the town contain trees of splendid quality, and provided the blight does not come in too severely these will be quite valuable for saw logs and poles ten or fifteen years hence.

Several areas of very large extent occur which have nothing but a growth of young chestnut and oak sprouts. These sprouts are generally infected with the bark disease, and from the present indications will amount to very little. Around the ponds in the east, and particularly in the southeast, the best timber occurs.

There are no sawmills or woodworking industries in Dudley. Portable sawmills have worked there recently, but have now moved elsewhere, evidently from lack of suitable material to operate upon.

The paper mill located at West Dudley uses only rags and old paper, and is in no way connected with the wood pulp industry.

Land Types.

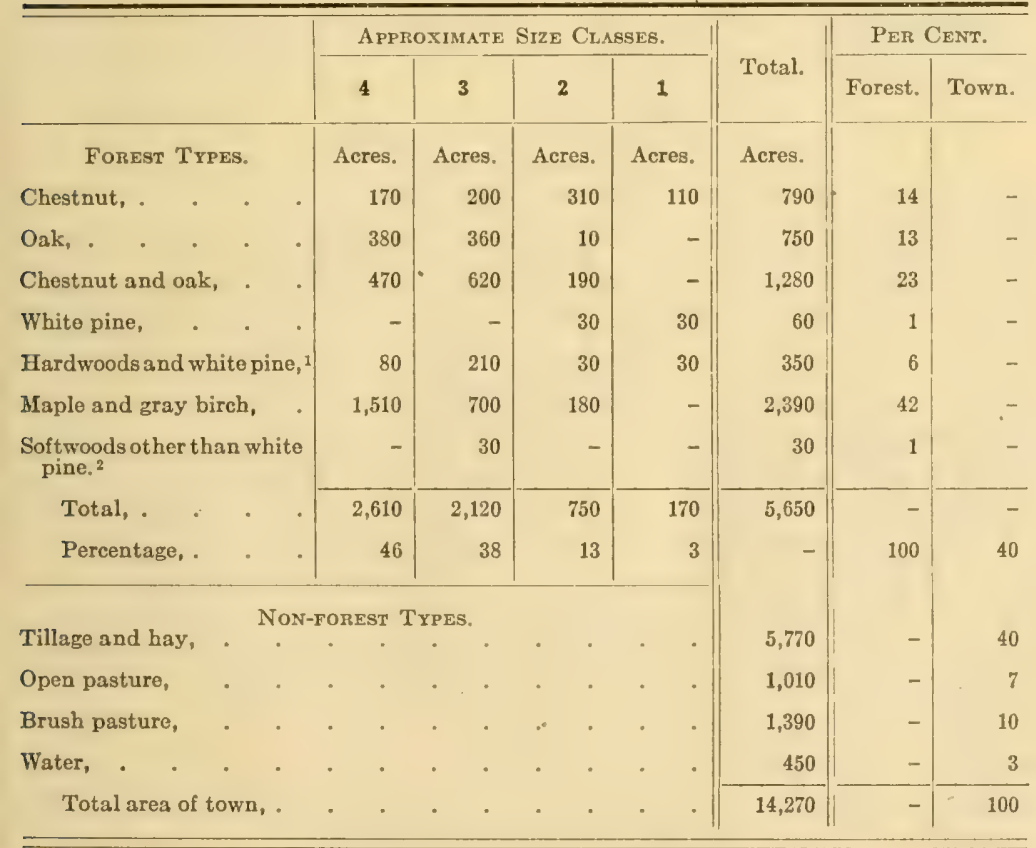

1 Hardwoods are red maple and gray birch.

2 White cedar. 
Fitchiurg.

About 50 per cent. of the town is made up of wood and sprout land. The principal types are white pine, pitch pine, oak and chestnut, with hemlock, maple, poplar, white and gray birch, beech, ash and other hardwoods. Clear stands are usually of pine, oak, chestnut and maple. Mixed stands of hardwood contain red maple in abundance, and a considerable amount of hard maple on the hills. The general condition of the wood growth is very good. There is not very much waste land in the town.

Fitchburg is not a large consumer of native lumber, but there are a few box manufacturers who take native pine and chestnut. Most of the lumber used in building operations and builder's finish comes from outside the State. The Crocker \& Burbank Company, paper manufacturers, use considerable lumber, spruce and hard and soft pine. They occasionally buy wood lots which they operate themselves. The Parkhill Manufacturing Company use pine and hemlock for cloth boards, and operate their own wood lots. Messrs. P. R. Eaton and I. P. Lawrence also operate locally.

\section{Box Makers.}

O. S. Cook \& Sons.

C. A. Priest Lumber Company.

Haldie Nickerson.
Webber Lumber Company.

S. G. Cushing \& Sons.

Chas. A. Priest Lumber Company.

\section{Lumber Dealers.}

Webber Lumber Company. H. A. Lawrence Company. P. R. Eaton.
E. E. Watson.

Wiley \& Foss.

Lawrence \& Klein Lumber Company.

Cordwood Dealers.

C. H. Greene.

Union Coal Company.

Wood Norelties.

Mossman Manufacturing Company. 
Land Types.

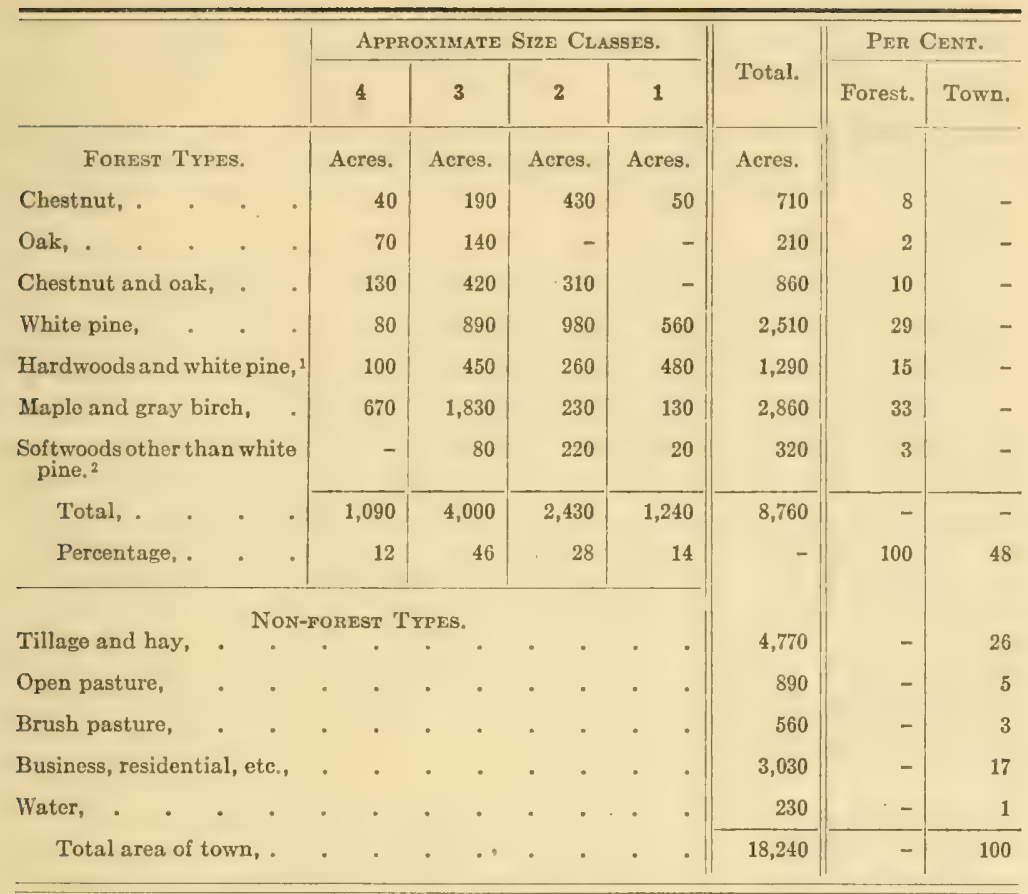

1 Hardwoods are red maple and birch.

2 About one-third pitch pine and two-thirds hemlock.

\section{GARDNER.}

No extensive areas of woodland occur. There is a considerable amount of forest scattered here and there in groups and separated by large logged areas, swamps and brushy pasture. The northern part of the town is more forested than the southern part. Much good white pine is found and a considerable amount of maple, beech and birch. The pine is mixed with maple, beech, birch, poplar and cherry rather than with chestnut and oaks, as it commonly is in the southern part of Worcester County. Both red and sugar maple are more plentiful here than in the southern part of the county. Extensive areas of swamp land bearing red and black spruce, larch and hemlock occur. These swamps contain a young growth scarcely large enough for box boards. 
Gardner uses probably more lumber than any other town in the State outside of Boston in manufacturing industries,. and the chief products are chairs and baby carriages. Naturally the bulk of the lumber used are hardwoods, and the leading species are birch, oak, chestnut, maple and beech. Considerable quantities of cheap pine and spruce are used for crating purposes.

Only about 20 per cent. of the lumber used in the industry is cut in this State, although the bulk of it comes within the limits of New England. Inasmuch as the lumber is cut up into small pieces, the chair manufacturers can utilize a rather low grade of hardwood lumber, Classes 1,2 and 3 common. The largest concern in Gardner is the Heywood Bros. \& Wakefield Company. This concern has mills also at Wakefield, Mass., and Chicago, Ill. When running to capacity it employs 1,700 hands and consumes 20,000,000 feet per year. The other chair-making concerns are much smaller and use from 2,000,000 to 5,000,000 feet per year. The following is a list of these manufacturers of chairs:-

S. Bent \& Brothers.

Conant, Ball \& Co.

P. Derby \& Co.

John A. Dunn Company.

Greenwood Associates.

Brown Brothers Company.

Pineo Manufacturing Company.
Kelly Brothers.

Howe Spalding.

Nichols \& Stone.

L. B. Ramsdell.

S. K. Pierce \& Son.

A. \& H. Knowlton.

In addition to the above manufacturers of chairs, the Central Oil Stove Company run a small sawmill at their plant at which they cut up cheap pine and spruce for crating shooks. L. A. Wright has a stationary mill in which they do custom sawing and planing, handling pine largely. Timothy E. Sheary manufactures boxes and carries on a general lumber business. E. Osgood \& Sons and L. H. Fendall are the chief dealers in cordwood. 
Land Types.

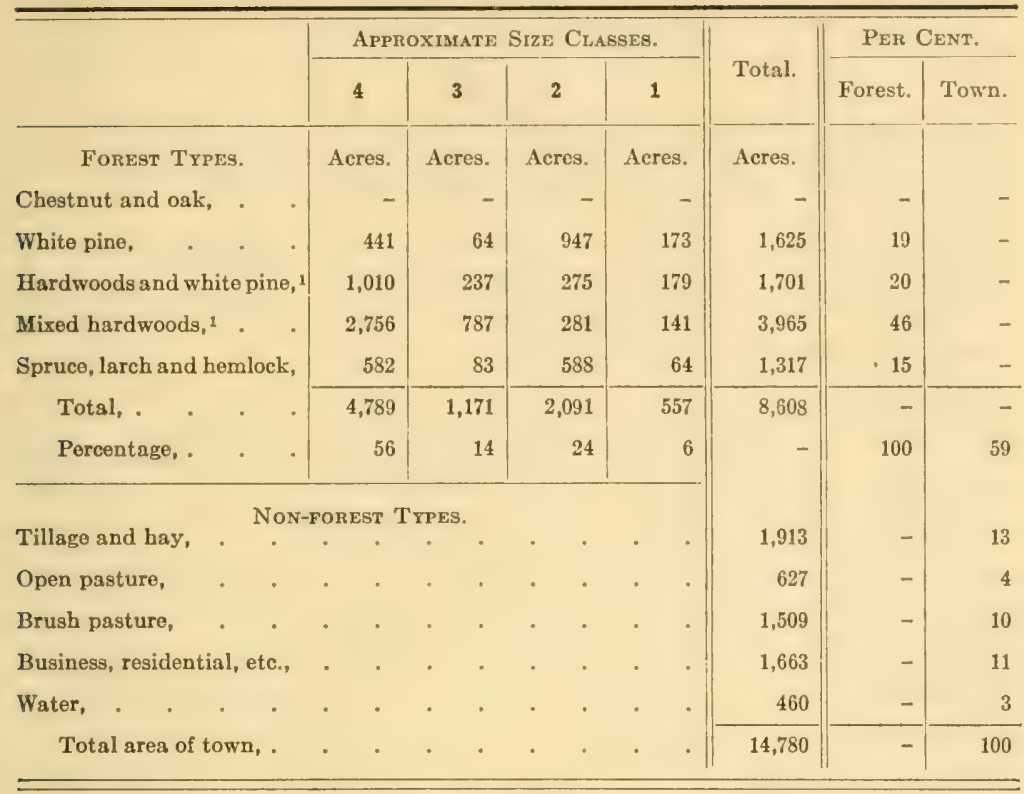

1 Smaller sized hardwoods are mostly gray birch; larger sized are maple, beech, ehestnut and oak.

\section{Grafton.}

The greater part of this town has been cleared for farming and pasture land. Timber land is relatively scarce, but where it does occur it is in excellent condition. Chestnut is the leading species, followed closely by oak and red maple. White pine is scarce. On some of the old fields and farms reproduction of white and pitch pine is rapidly taking possession. Numerous small areas of gray birch are found scattered throughout the entire town. A few excellent stands occur. Just east of the Country Club is a stand of chestnut of Class 2 with an 85 per cent. stocking. Some of the trees will run to Class 1. The bulk of the timber lies in the eastern quarter of the town in scattered wood lots of from 5 to 50 acres. This ranges from Class 1 to Class 3, the larger part being in Class 2.

Grafton has no permanent sawmills or woodworking industries. 
Land Types.

\begin{tabular}{|c|c|c|c|c|c|c|c|c|}
\hline & & \multicolumn{4}{|c|}{ Approximate Size Classes. } & \multirow{2}{*}{ Total. } & \multicolumn{2}{|c|}{ Per Cent. } \\
\hline & & 4 & 3 & 2 & 1 & & Forest. & Town. \\
\hline \multicolumn{2}{|c|}{ Forest Trpes. } & Acres. & Acres. & Acres. & Acres. & Acres. & & \\
\hline Chestnut, . & $\cdot$ & 199 & 149 & 336 & 653 & 1,337 & 25 & - \\
\hline Oak, . . & - & 105 & 149 & 118 & 12 & 384 & 7 & - \\
\hline Chestnut and oak, & $k, \quad \cdot \quad \cdot$ & 690 & 503 & 174 & 87 & 1,454 & 28 & - \\
\hline White pine, & . & - & 12 & - & - & 12 & & 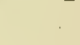 \\
\hline \multicolumn{2}{|c|}{ Hardwoods and white pine, ${ }^{1}$} & 155 & 131 & 44 & - & 330 & 6 & - \\
\hline \multicolumn{2}{|c|}{ Maple and gray birch, } & 945 & 696 & 62 & - & 1,703 & 32 & - \\
\hline \multirow{2}{*}{$\begin{array}{c}\text { Pitch pine, } \\
\text { Total, . }\end{array}$} & - & - & 31 & 50 & - & 81 & 2 & - \\
\hline & $\cdot$ & 2,094 & 1,671 & 784 & 752 & 5,301 & - & - \\
\hline Percentage, . & $\cdot$ & 40 & 31 & 15 & 14 & - & 100 & 35 \\
\hline \multicolumn{6}{|c|}{ NON-FOREST TYPES, } & 5,966 & - & 40 \\
\hline Open pasture, & - & . & - & - & - & 2,020 & - & 14 \\
\hline Brush pasture, & . & - & - & - & - & 1,264 & - & 8 \\
\hline \multicolumn{2}{|c|}{ Business, residential, etc., } & . & - & . & - & 261 & - & 2 \\
\hline Water, . & $\cdot \quad$. & . & . & . & - & 118 & - & 1 \\
\hline \multicolumn{2}{|c|}{ Total area of town, . } & - & - & $\cdot$ & - & 14,930 & - & 100 \\
\hline
\end{tabular}

1 Mostly gray birch with a little white pine.

\section{HARDWICK.}

Commercially speaking, chestnut is the most distinctive tree in the town of Hardwick, and there is an unusua amount of commercial size present. White pine follows closely on chestnut, but it runs rather smaller. 'The western part of the town is the most extensively wooded, but a considerable area in this section was burned over in a large fire some years ago, so that the woodland of better quality will be found in the eastern and central parts.

There are no wood-using industries in this town, unless the paper mill at Wheelwright can be called such. The wood pulp used in this mill, however, all comes from mills in Maine and New Hampshire. A Mr. Spooner on the Greenwich road has a water mill which apparently is seldom used. A Mr. Howard on the Gilbertville road has a water mill which is still in use. Formerly he operated and sawed timber from his own lands, 
but his work now is largely confined to custom sawing of logs brought in. Chestnut is the chief product, and is put into dimension lumber for local building purposes.

Land Types.

\begin{tabular}{|c|c|c|c|c|c|c|c|c|}
\hline & & \multicolumn{4}{|c|}{ Approximate Size Classes. } & \multirow{2}{*}{ Total. } & \multicolumn{2}{|c|}{ Per Cent. } \\
\hline & & 4 & 3 & 2 & 1 & & Forest. & Town. \\
\hline \multicolumn{2}{|c|}{ FOREST TYPES. } & Acres. & Acres. & Acres. & Acres. & Acres. & & \\
\hline Chestnut, . & . & 180 & 630 & 620 & 970 & 2,400 & 17 & - \\
\hline Oak, . . . & . & 220 & 170 & 20 & - & 410 & 3 & - \\
\hline \multicolumn{2}{|l|}{ Chestnut and oak, } & 230 & 310 & 400 & - & 940 & 7 & - \\
\hline \multicolumn{2}{|c|}{ Hardwoods and white pine, 1} & 1,220 & 3,550 & 150 & 160 & 5,080 & 36 & - \\
\hline White pine, & $\cdot \quad \cdot$ & 130 & 710 & 290 & 500 & 1,630 & 12 & - \\
\hline Maple and birch, & $\cdot \quad \cdot$ & 1,080 & 940 & 160 & 140 & 2,320 & 17 & - \\
\hline \multicolumn{2}{|c|}{$\begin{array}{l}\text { Softwoods other than white } \\
\text { pine. } 2\end{array}$} & 90 & 700 & 100 & 270 & 1,160 & 8 & - \\
\hline Total, . & . & 3,150 & 7,010 & 1,740 & 2,040 & 13,940 & - & - \\
\hline Percentage, . & $\cdot$ & 23 & 50 & 12 & 15 & - & 100 & 54 \\
\hline \multicolumn{6}{|c|}{ Tillage and hay, NoN-Forest Trpes, } & 3,280 & - & 13 \\
\hline Open pasture, & . & - & - & - & - & 5,530 & - & 22 \\
\hline Brush pasture, & - & - & - & - & . & 2,540 & - & 10 \\
\hline \multicolumn{2}{|c|}{ Business, residential, etc., } & - & - & - & - & 110 & \multirow{2}{*}{-} & \multirow{2}{*}{1} \\
\hline Water, . & - & - & - & - & - & 200 & & \\
\hline \multicolumn{2}{|c|}{ Total area of town, . } & . & - & - & $\cdot$ & 25,600 & - & 100 \\
\hline
\end{tabular}

1 Hardwoods are mostly maple.

2 About 50 per cent. pitch pine; remainder, largely hemlock.

\section{HARVARD.}

The hills in this town are covered mostly with the chestnut and oak type, with considerable white pine in mixture and as an understory. Frequent stands of white pine occur on ridges and benches. In the northeastern part of the town near Shaker River is an extensive stand of white pine of first quality and size. Similar stands are also found on some flat land extending into, but raised above, the great swamp in the southwestern part of the town. Poplar and maple are found in the swamps of the stream bottoms, while on raised situations some pine is found. Gray birch is rapidly coming into the old pastures and in small tracts where there is an outcropping of sandy or rocky 
soil. The extensive sand barren in the northwest part of the town is covered by a sparse growth of pitch pine with occasional bunches of white pine where there is better soil or more moisture available. The general condition of the woodlands is good. There are, however, many local areas where thimnings are needed.

Mr. E. J. McLaughlin owns and operates a mill in which he saws pine for box boards and chestnut for chair stock, barrel staves and heading. Some poplar and pine are also used for the latter products. There is a planer in the mill and also stave and barrel-head making machinery. Mr. McLaughlin also operates local wood lots.

Land Types.

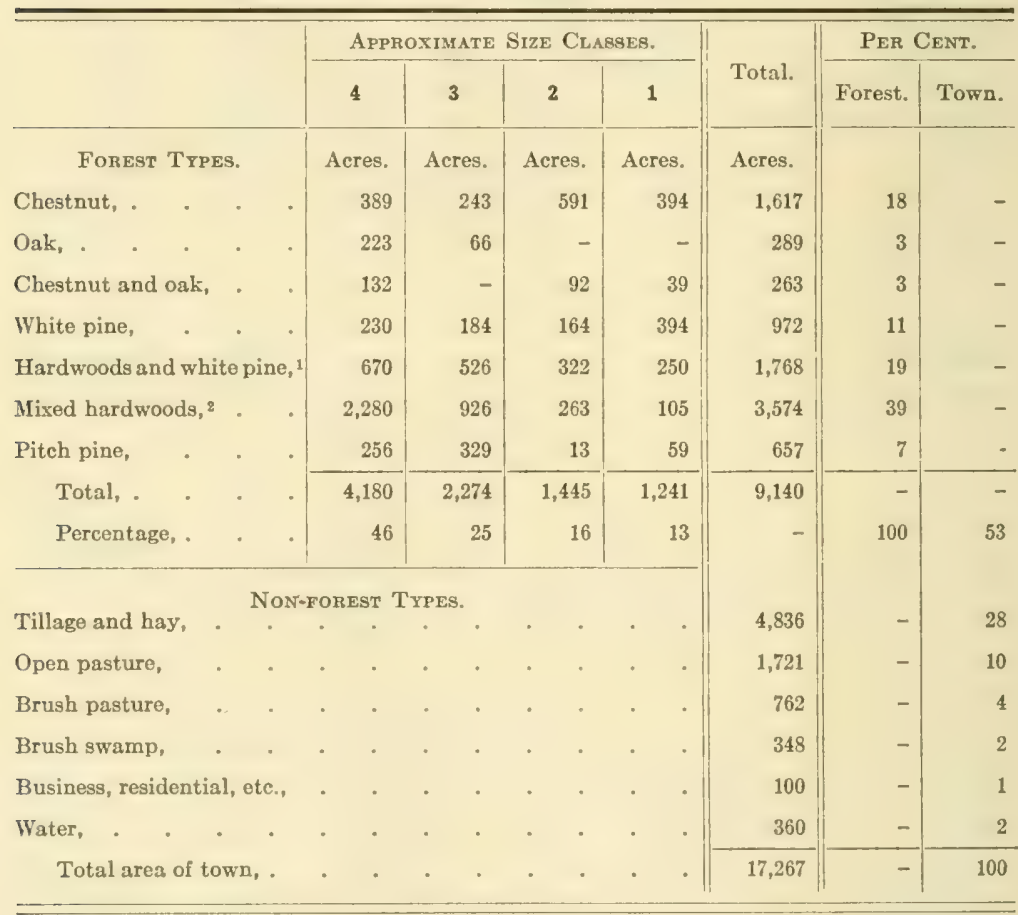

1 Hardwoods are made up of about 30 per cent. chestnut and oak, 40 per cent. gray birch and 30 per cent. maple.

2 About 30 per cent. chestnut, 30 per cent. gray birch and 40 per cent. maple.

\section{IIOLDEN.}

About 65 per cent. of the town is covered with a woody growth. Chestnut is the leading species, followed closely by oak. Numerous thick stands of birch occur, generally of Class 
4 and up to Class 3 . White pine is well distributed, and in the northeastern part of the town occurs very abundantly. Threequarters of a mile south from the northeast corner is an area of several hundred acres of pure white pine varying in size from Class 4 to a small Class 1. Just across the road from this, and extending to the Boylston line, is an area of about the same size of pure chestnut, Classes 3 to 2, and stocked to a full 100 per cent. Stone House Hill is practically covered with chestnut, and chestnut and oak, of an average Class 3 to Class 2.

Asnebumskit Hill is almost entirely covered with woods. These are generally mixed hardwoods and mixed hardwoods and pine, although extensive areas of birch reproduction and brush pastures are found enclosed. Most of the woods have a heavy undergrowth of laurel.

Waldo E. Austin owns a sawmill and box mill. Chestnut and pine are cut almost exclusively. This mill works in the spring and cuts logs for private owners.

Land Types.

\begin{tabular}{|c|c|c|c|c|c|c|c|c|c|}
\hline & & & \multicolumn{4}{|c|}{ Approximate Size Classes. } & \multirow{2}{*}{ Total. } & \multicolumn{2}{|c|}{ Per Cent. } \\
\hline & & & 4 & 3 & 2 & 1 & & Forest. & Town. \\
\hline \multicolumn{3}{|c|}{ Forest Types. } & Acres. & Acres. & Acres. & Acres. & Acres. & & \\
\hline Chestnut, . & & - & 598 & 1,170 & 1,298 & 71 & 3,137 & 21 & - \\
\hline Oak, . & & - & 270 & 270 & 64 & - & 604 & 4 & - \\
\hline Chestnut and oak & - & - & 1,774 & 1,813 & 1,099 & 90 & 4,776 & 31 & - \\
\hline White pine, & - & . & 116 & 296 & 315 & 251 & 978 & 6 & - \\
\hline \multicolumn{3}{|c|}{ Hardwoods and white pine, 1} & 701 & 913 & 84 & 19 & 1,717 & 11 & - \\
\hline \multicolumn{2}{|c|}{ Maple and gray birch, } & - & 2,012 & 1,581 & 315 & 103 & 4,011 & 27 & - \\
\hline Total, . . & 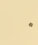 & $\cdot$ & 5,471 & 6,043 & 3,175 & 534 & 15,223 & - & - \\
\hline Percentage, . & - &. & 36 & 40 & 21 & 3 & - & 100 & 66 \\
\hline \multicolumn{7}{|c|}{ NON-FOREST TYPES. } & 4,776 & - & 21 \\
\hline Open pasture, & . & . & . & . & - & . & 1,902 & -1 & 8 \\
\hline Brush pasture, & . & . & . & - & - & . & 764 & - & 3 \\
\hline \multicolumn{3}{|c|}{ Business, residential, etc., } & - & - & . & . & 64 & - & 2 \\
\hline Water, . & . & . & - & . & - & . & 405 & & \\
\hline \multicolumn{3}{|c|}{ Total area of town,. } & . & . & . & . & 23,134 & - & 100 \\
\hline
\end{tabular}

1 Hardwoods are chiefly swamp maple and gray birch. 


\section{Hopedale.}

Chestnut is the most important tree, but considerable quantities of white pine occur also. The timber in the northern part of the town runs from 1 to a small 2 size, while in the southern part it is mostly found in the 4 and 3 classes. The timber on the land owned by the Draper Company and the town (750 acres) is almost all ready to cut, some of the pine running up to 90 feet high, and 30 inches diameter, breast high.

There are no sawmills or operators in Hopedale, the most of the land being kept as a sort of reservation.

The Draper Company uses a considerable quantity of lumber, keeping $\$ 500,000$ worth on hand all the time. Most of this is used in building houses and repair work. It uses the following stock: ash from Vermont and New Hampshire; Oregon pine from Washington; cedar shingles from Washington; and small quantities of chestnut and pine from surrounding towns.

Land Types.

\begin{tabular}{|c|c|c|c|c|c|c|c|c|c|}
\hline & & & \multicolumn{4}{|c|}{ Approximate Size Classes. } & \multirow{2}{*}{ Total. } & \multicolumn{2}{|c|}{ Per Cent. } \\
\hline & & & 4 & 3 & 2 & 1 & & Forest. & Town. \\
\hline \multicolumn{3}{|c|}{ Forest TYPES. } & Acres. & Acres. & Acres. & Acres. & Acres. & & \\
\hline Chestnut, . & . & - & 260 & 50 & 120 & 60 & 490 & 26 & - \\
\hline Oak, . . & - & . & 90 & - & - & - & 90 & 5 & - \\
\hline Chestnut and oak, & - & . & - & 40 & - & - & 40 & 2 & - \\
\hline White pine, & . & $\cdot$ & 80 & 30 & 40 & 50 & 200 & 11 & - \\
\hline \multicolumn{3}{|c|}{ Hardwoods and white pine, 1} & 50 & 120 & 20 & - & 190 & 10 & - \\
\hline \multicolumn{2}{|c|}{ Maple and gray birch, } & $\cdot$ & 280 & 470 & 80 & - & 830 & 44 & - \\
\hline Pitch pine, $\quad \because$ & . & $\cdot$ & 30 & - & - & - & 30 & 2 & - \\
\hline Total, . & . & . & 790 & 710 & 260 & 110 & 1,870 & - & - \\
\hline Percentage, . & - & - & 42 & 38 & 14 & $6 !$ & - & \multirow{2}{*}{$\begin{array}{r}100 \\
-\end{array}$} & 56 \\
\hline \multicolumn{7}{|c|}{ NON-FOREST TYPES. } & 670 & & 20 \\
\hline Open pasture, & - & - & . & . & - & - & 140 & - & 4 \\
\hline Brush pasture, & - & - & $\because$ & - & - & - & 300 & - & 9 \\
\hline \multicolumn{3}{|c|}{ Business, residential, etc, } & . & $\cdot$ & - & - & 280 & - & 8 \\
\hline Water, . & - & - & $\cdot$ & . & $\cdot$ & $\cdot$ & 110 & - & 3 \\
\hline \multicolumn{3}{|c|}{ Total area of town, . } & . & . & - & . & 3,370 & - & 100 \\
\hline
\end{tabular}

1 Hardwoods are principally red maple with some birch. 


\section{HUBBaRdston.}

Practically all trees found in this State are found in this town, although pitch pine and spruce are rare. The leading types are birch (mostly gray), red maple and pine. Chestnut and oak, while common, exist scattered among other types. There is an unusual amount of pine reproduction, and if allowed to grow it will make Hubbardston one of the leading pine torwns in the State.

In Hubbardston village there is a blanket mill employing a few hands. There is a sawmill and box shop on the depot road, but it is not now running. The Roper Box Company at East Hubbardston operate a sawmill and box shop. William Clark holds considerable timber land which operates through hired mills. W. E. Coffin and S. A. Bigelow, owners of portable mills, operate extensively in Hubbardston and vicinity.

Land Types.

\begin{tabular}{|c|c|c|c|c|c|c|c|c|}
\hline & & \multicolumn{4}{|c|}{ Approximate Size Classes. } & \multirow{2}{*}{ Total. } & \multicolumn{2}{|c|}{ Per Cent. } \\
\hline & & 4 & 3 & 2 & 1 & & Forest. & Town. \\
\hline \multicolumn{2}{|c|}{ Forest TrPes. } & Acres. & Acres. & Acres. & Acres. & Acres. & & \\
\hline Chestnut, . & . & 110 & 90 & 180 & 10 & 390 & 2 & - \\
\hline Beech, & . & 60 & 150 & 70 & - & 280 & 2 & - \\
\hline Oak, . & . & 280 & 660 & 10 & 20 & 970 & 5 & - \\
\hline White pine, & . & 1,130 & 2,070 & 1,580 & 320 & 5,100 & 28 & - \\
\hline \multicolumn{2}{|c|}{ Maple and gray birch, 1} & 6,810 & 3,170 & 500 & 10 & 10,490 & 57 & - \\
\hline \multicolumn{2}{|c|}{$\begin{array}{l}\text { Softwoods other than white } \\
\text { pine. }{ }^{2}\end{array}$} & 180 & 650 & 340 & 30 & 1,200 & 6 & - \\
\hline Total, . & - & 8,570 & 6,790 & 2,680 & 390 & 18,430 & - & - \\
\hline Percentage, . & . & 46 & 37 & 15 & 2 & - & 100 & 69 \\
\hline \multicolumn{6}{|c|}{ NON-FOREST TYPES. } & 3,510 & -1 & 13 \\
\hline Open pasture, & - & . & - & . & . & 880 & - & 3 \\
\hline Brush pasture, & . & . & . & . & . & 1,480 & -1 & 6 \\
\hline Brush swamp, & - & - & . & . & . & 1,410 & - & 5 \\
\hline \multicolumn{2}{|c|}{ Business, residential, etc., } & . & . & . & . & 770 & - & 3 \\
\hline Water, . & . & - & . & . & . & 210 & - & 1 \\
\hline \multicolumn{2}{|c|}{ Total area of town, . } & . & . & . & . & 26,690 & - & 100 \\
\hline
\end{tabular}

1 Considerable poplar and alder included in Classes 3 and 4.

2 Mostly hemlock and spruce. 


\section{LANCASTER.}

The proportion of wooded land to the total area of the town is about 60 per cent. The best woodland lies in the southwest, between the river valley and the town line, along the George Hill and Ballard Hill ridges. The types are usually well defined, the most important being pine, oak, chestnut, soft maple and birch, in clear and in mixed stands. Reforestation is popular on the larger estates; white pine is preferred. The plantations show rapid and healthy growth.

The area in the northeast corner, bounded by Crumbury Pond, Shirley Road and the Nashua River, has a good covering of young pine, both white and pitch. The growth is not uniform, however, and a large amount of brush, dead trees and fallen birch should be removed to bring it into the best condition.

The rest of the town, except for a few acres surrounding the lakes, has been swept by forest fires. The reproduction consists of oak, chestnut, birch, soft maple and aspen, and in some cases a little pine.

Practically no cutting for lumber is done by residents of Lancaster. There is one small chair factory on the Leominster road at Wekepeke Brook. The owner is W. W. Bartlett of Lancaster. Some cutting is done in this town by the lumbermen of Clinton. 
Land Types.

\begin{tabular}{|c|c|c|c|c|c|c|c|c|}
\hline & & \multicolumn{4}{|c|}{ Approximate Size Classes. } & \multirow{2}{*}{ Total. } & \multicolumn{2}{|c|}{ Per Cent. } \\
\hline & & 4 & 3 & 2 & 1 & & Forest. & Town. \\
\hline \multicolumn{2}{|c|}{ FOREST TYPES. } & Acres. & Acres. & Acres. & Acres. & Acres. & \multirow[b]{2}{*}{0} & \multirow[b]{2}{*}{-} \\
\hline Chestnut, . &. & 40 & 170 & 80 & 430 & 720 & & \\
\hline Oak, . & . & 1,220 & 900 & 80 & - & 2,200 & 19 & - \\
\hline Chestnut and oak, & . & 780 & 1,430 & 120 & 280 & 2,610 & 23 & - \\
\hline White pine, & . & 160 & 940 & 120 & 800 & 2,020 & 18 & - \\
\hline \multicolumn{2}{|c|}{ Hardwoods and white pine, 1} & 70 & 390 & 1,080 & 80 & 1,620 & 14 & - \\
\hline \multirow{2}{*}{\multicolumn{2}{|c|}{$\begin{array}{l}\text { Maple and gray birch, } \\
\text { Softwoods other than white } \\
\text { pine. }{ }^{2}\end{array}$}} & 350 & 1,180 & 130 & 40 & 1,700 & 15 & - \\
\hline & & 60 & 220 & 200 & 110 & 590 & 5 & - \\
\hline Total, . & - & 2,680 & 5,230 & 1,810 & 1,740 & 11,460 & - & - \\
\hline Percentage, . & $\cdot 1$ & 23 & 46 & 16 & 15 & - & 100 & 63 \\
\hline \multicolumn{6}{|c|}{ NON-FOREST TYPES. } & 5,360 & - & 29 \\
\hline Open pasture, & . & . & . & . & . & 480 & - & 3 \\
\hline Brush pasture, & . & - & - & . & . & 530 & - & 3 \\
\hline \multicolumn{2}{|c|}{ Business, residential, etc., } & . & . & . & - & 150 & - & 1 \\
\hline Water, . & • & . & - & . & - & 130 & - & 1 \\
\hline \multicolumn{2}{|c|}{ Total area of town,. } & . & . & . & . & 18,110 & - & 100 \\
\hline
\end{tabular}

1 Hardwoods are maple and gray birch.

2 Largely pitch pine with about 50 acres of hemlock.

\section{LEICESTER.}

The principal woodland types are soft maple and gray birch, either separately or in mixture, chestnut, oak and white pine. There is a fair representation of older age classes. The pastures contain much sweet fern and sumac. Around the reservoir of Worcester water board on Kettle Brook there are some plantations of white pine.

There are no wood-using industries in the town and no permanent sawmills. There is a good market for box lumber, poles, ties and cordwood in Worcester, so that timber lots are cut as soon as they become of merchantable size. Southwick and Barry are the leading local operators and deal principally in chestnut products. 
Land Types.

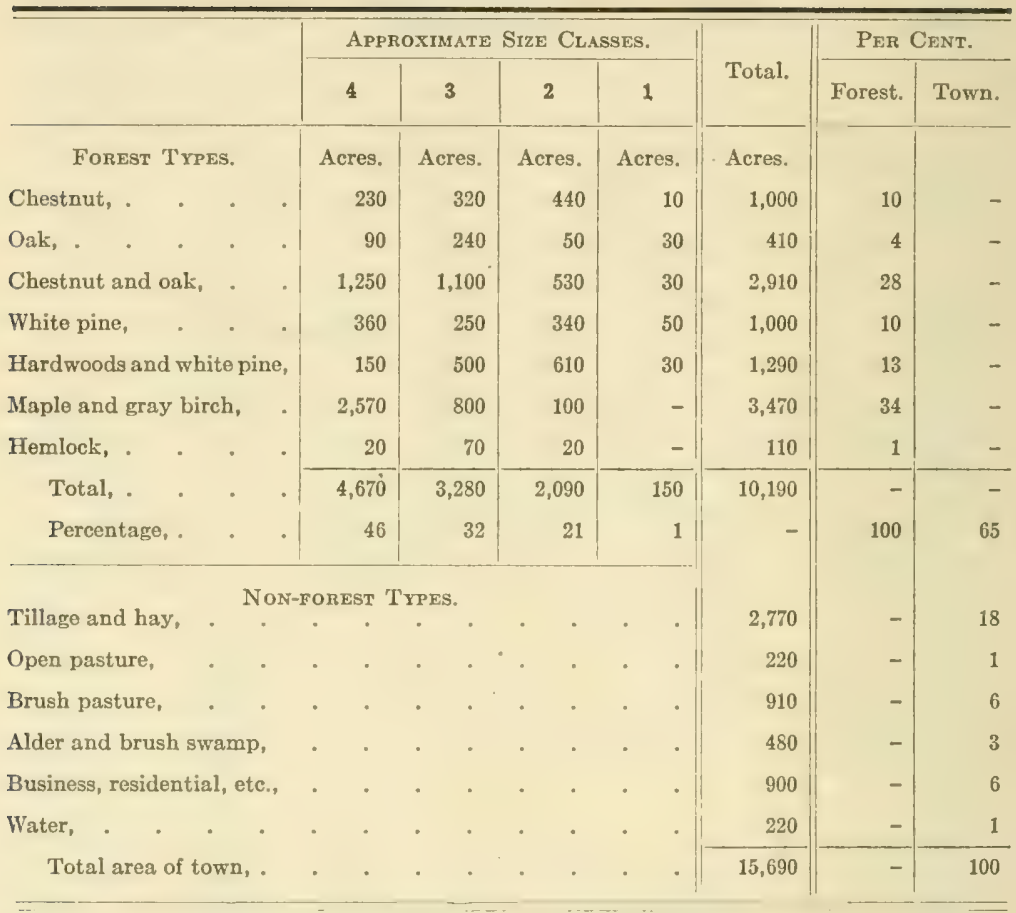

\section{LEOMINSTER.}

About 50 per cent. of this town's area is wooded. The majority of the timber is in only fair condition, owing to forest fires and tree diseases. Chestnut is the leading species, and is the principal tree covering the large hills. White pine occurs everywhere, but not in such large and continuous stands as the chestnut. The chestnut and oak sprout lands and mixtures of white pine and gray birch occur abundantly and in about equal proportion. The white pine is in good healthy condition and growing rapidly wherever it occurs. Size classes range from the largest to the smallest. The majority of the stands, however, will fall under Class 3 . Leaving out all trees under 6 inches, the average will run about $S$ to 10 inches diameter, breast high.

No sawmills were found. Woodworking industries represent more capital than any phase of manufacturing in Leominster. 
It is estimated that over $10,000,000$ board feet are worked up annually in this eity. Among the most prominent lumberusing and woodworking industries are the following: -

Whitney Reed Corporation.

E. G. Smith Piano Case Company. J. H. Lockey \& Co., Piano Cases. Leominster Novelty Company.

Merriam Hall Furniture Company.
W. A. Fuller Lumber Company. Richardson Piano Case Company. Jewett Piano Case Company. Wellington Piano Case Company. E. A. Whitney Carriage Company.

The output of these concerns varies from 500,000 to 2,500,000 board feet annually. Practically all of the native woods and much foreign wood are used in the various products.

Land Types.

\begin{tabular}{|c|c|c|c|c|c|c|c|c|}
\hline & & \multicolumn{4}{|c|}{ Approximate Size Classes. } & \multirow{2}{*}{ Total. } & \multicolumn{2}{|c|}{ Per Cent. } \\
\hline & & 4 & 3 & 2 & 1 & & Forest. & Town. \\
\hline \multicolumn{2}{|c|}{ Forest Trpes. } & Acres. & Acres. & Acres. & Acres. & Acres. & & \\
\hline Chestnut, . & .1 & 122 & 875 & 617 & 32 & 1,646 & 19 & - \\
\hline Oak, . . &. & 411 & 251 & - & 90 & 752 & 9 & - \\
\hline Chestnut and oak, &. & 998 & 811 & 264 & - & 2,073 & 24 & - \\
\hline White pine, & $\cdot$ & 64 & 359 & 462 & 392 & 1,277 & 14 & - \\
\hline \multicolumn{2}{|c|}{ Hardwoods and white pine, 1} & 130 & 83 & - & - & 213 & 2 & - \\
\hline \multicolumn{2}{|c|}{ Maple and gray birch, } & 707 & 1,620 & 150 & 85 & 2,562 & 29 & - \\
\hline Pitch pine, & $\cdot 1$ & 13 & 202 & 27 & 6 & 248 & 3 & - \\
\hline Total, . & $\cdot 1$ & 2,445 & 4,201 & 1,520 & 605 & 8,771 & - & - \\
\hline Percentage, . & $\cdot 1$ & 28 & 48 & 17 & 7 & \multirow[t]{2}{*}{-} & 100 & \multirow[t]{2}{*}{47} \\
\hline \multicolumn{6}{|c|}{ Tillage and hay, NON-FOREST TYPES. } & & 27 & \\
\hline Open pasture, & - & . & . & - & . & 2,703 & - & 14 \\
\hline Brush pasture, & . & . & - & - & . & 517 & - & 3 \\
\hline Business, residenti & al, etc., & - & . & - & . & 1,327 & - & 7 \\
\hline Water, : & . & - & - & - & - & 451 & - & 2 \\
\hline Total area of $t$ & own, . & . & . & . & . & 18,817 & - & 100 \\
\hline
\end{tabular}

I Hardwoods are gray birch, red maple and poplar.

\section{LUNENBURG.}

The proportion of forest land to the total area of the town is about 65 per cent. The general condition is very good. Most of the woodland lies north of Lunenburg village, but there 
are a few excellent lots of young timber trees in the middle and southern sections. The town has recently purchased 20 acres of pine land, size Classes 2 to 1 , stocked nearly 100 per cent., just north of the village. It will be used as a park. The principal types found in Lunenburg are white pine, pitch pine, chestnut, oak, maple, poplar and gray birch. Most of the land is utilized, and waste tracts are very rare.

H. B. Francis of Lunenburg cuts about 100 M board feet per year of pine, chestnut and hardwoods and about 200 cords of wood.

Land Types.

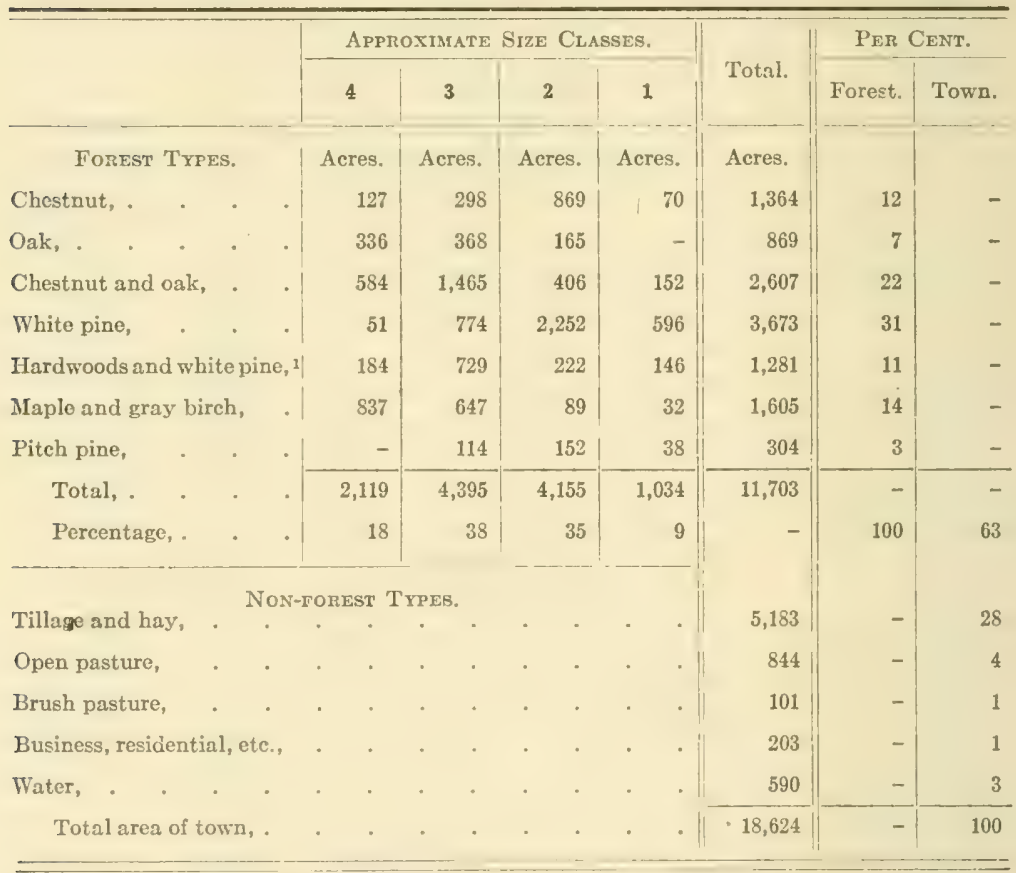

1 Hardwoods are gray birch and maple.

\section{MENDON.}

Although sizes 4 to 3 are the prevailing size classes, yet 20 per cent. or more of the timbered land has sizes 3 to 2 on it, mostly chestnut and oak with a little good merchantable pine. Mendon fares better than most of the surrounding towns in having a fair proportion of the cut-over lots coming in to pine. 
Comparative freedom from fires may account for this to some degree.

There are no mills working in Mendon and no woodworking industries are located there. C. A. Fletcher buys and cuts off lots in Mendon and surrounding towns.

Land Types.

\begin{tabular}{|c|c|c|c|c|c|c|c|c|c|}
\hline & & & \multicolumn{4}{|c|}{ Approximate Size Crasses. } & \multirow{2}{*}{ Total. } & \multicolumn{2}{|c|}{ Per Cent. } \\
\hline & & & 4 & 3 & 2 & 1 & & Forest. & Town. \\
\hline \multicolumn{3}{|c|}{ FOREST TYPES. } & Acres. & Acres. & Acres. & Acres. & Acres. & & \\
\hline Chestnut, . & & & 172 & 303 & 99 & 20 & 594 & 8 & - \\
\hline Oak, . . & - & . & 317 & 185 & - & - & 502 & 7 & - \\
\hline \multicolumn{2}{|l|}{ Chestnut and oak, } & . & 224 & 376 & 277 & 73 & 950 & $13 \mid$ & - \\
\hline White pine, & . & - & 152 & 53 & - & 46 & 251 & 31 & - \\
\hline \multicolumn{3}{|c|}{ Hardwoods and white pine, 1} & 270 & 152 & 125 & 13 & 560 & 7 & - \\
\hline \multicolumn{3}{|c|}{ Maple and gray birch, } & 2,936 & 825 & 600 & - & 4,361 & 59 & - \\
\hline Pitch pine, & . & . & 53 & 132 & 33 & - & 218 & 3 & - \\
\hline Total, . & . & $\cdot$ & 4,124 & 2,026 & 1,134 & 152 & 7,436 & - & - \\
\hline Percentage, . & - & $\cdot 1$ & 56 & 27 & 15 & 2 & - & 100 & 65 \\
\hline Tillage and hay, & . & $\begin{array}{l}\text { NoN-F } \\
\text {. }\end{array}$ & GOREST T & XPES. & - & $\cdot$ & 2,427 & - & 21 \\
\hline Open pasture, & - & - & - & . & . & - & 824 & -1 & 7 \\
\hline Brush pasture, & . & - & - & - & - & - & 732 & - & 6 \\
\hline Water, & - & - & - & . & . & - & 165 & - & 1 \\
\hline \multicolumn{3}{|c|}{ Total area of town, . } & . & - & - & . & 11,584 & - & 100 \\
\hline
\end{tabular}

1 Hardwoods are largely gray birch, red maple and oaks.

\section{MiLFORD.}

The strong market for cordwood and the ready market for saw stock as well have operated to keep the timber pretty well cut. Only a small percentage, perhaps 15 per cent., is older than Class 3, and by far the greater part would be classed as 4. Pitch pine takes the place of white pine to a considerable extent, but neither is present in anything approaching merchantable quantities. Chestnut, soft maple and oaks (black, red, scrub, white and chestnut) are the most important of the hardwoods. Between Cedar Street and the Holliston line are considerable quantities of scrub oak and chestnut oak. 
There are no sawmills, either stationary or portable, in Milford. There are no operators resident in the town, but C. A. Fletcher of Mendon and D. W. Gaskill of Blackstone have done some cutting in the past. For the most part the owners cut their own wood, delivering it to the local cordwood dealers.

Z. C. Field Lumber Company use about 4,000,000 feet of lumber per year. Practically all of this lumber comes from outside of the State, and consists of white pine, western yellow pine, spruce, cypress, whitewood and hemlock. Most of their white pine is obtained from Canada.

S. A. Eastman Box Company use annually about 175 M board feet of native white pine.

Land Types.

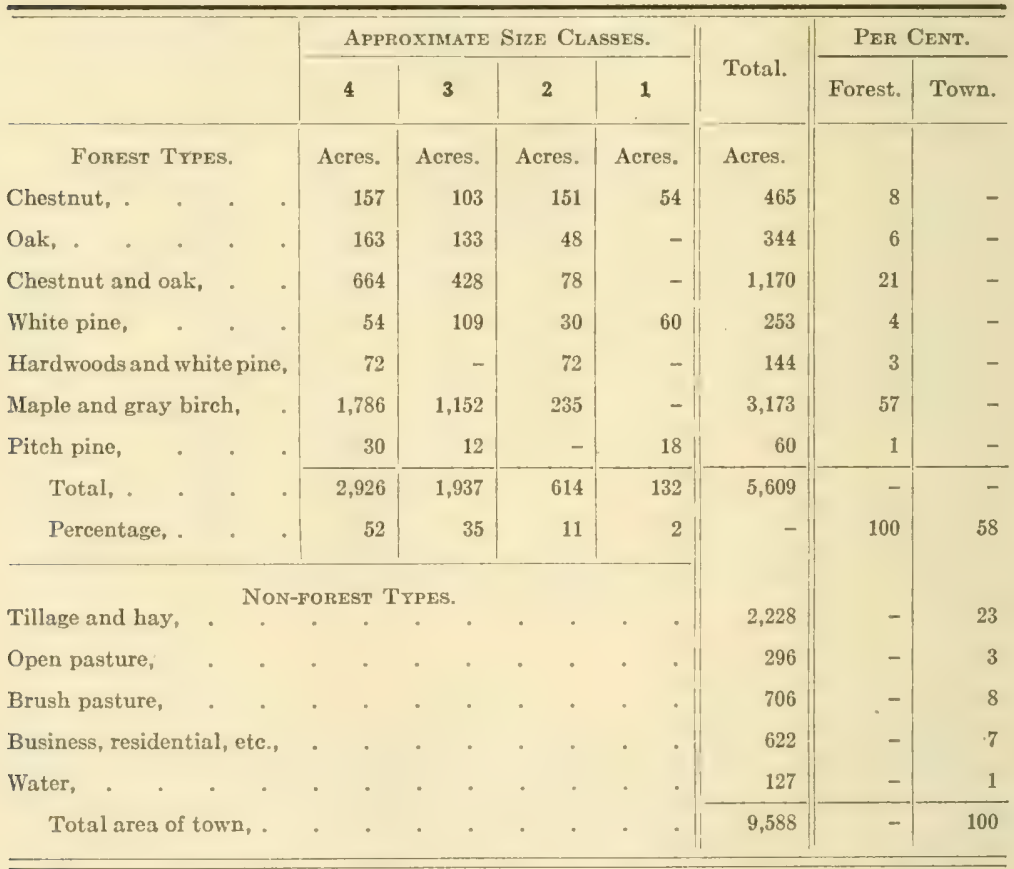

\section{Millbury.}

The condition of the woods of the southwest portion is very good. The soil is excellent, and fires have not done much damage. Chestnut and red maple are the principal trees. There is a little scattering of white pine and a few small stands of good merchantable pine. Of the comparatively small 
acreage of timber in the town, mostly chestnut and oals, little is merchantable at present. The best lies along the Oxford and Auburn sides. The cut-over areas are reproducing well. There are some brushy pastures coming into gray birch and fuel wood, with a very little white pine in places, and there are also considerable areas where repeated fires have left little but scrub) oak and gray birch. Throughout the town, and especially in the east, are maple swamps, usually small in area.

There are three sawmills owned in Millbury. The owners are W. R. Howe, W. A. Harris and A. W. Rice. These are all small mills, sawing from $50 \mathrm{M}$ to $150 \mathrm{M}$ board feet per year when running; practically all local stock. 'The only woodworking industry is a small outfit at Vest Millbury making tool handles, used mostly by the local edge tool factories of which there are two.

Land Types.

\begin{tabular}{|c|c|c|c|c|c|c|c|c|}
\hline & & \multicolumn{4}{|c|}{ Approximate Size Classes. } & \multirow{2}{*}{ Total. } & \multicolumn{2}{|c|}{ Per Cent. } \\
\hline & & 4 & 3 & 2 & 1 & & Forest. & Town. \\
\hline \multicolumn{2}{|c|}{ Forest Trpes. } & Acres. & Acres. & Acres. & Acres. & Acres. & & \\
\hline Chestnut, . & - & 190 & 289 & 221 & 160 & 860 & 18 & - \\
\hline Chestnut and oak & $\therefore$ & 307 & 313 & 264 & 37 & 921 & 19 & - \\
\hline White pine, & - & 6 & - & 43 & 98 & 147 & 3 & - \\
\hline \multicolumn{2}{|c|}{ Hardwoods and white pine, } & 258 & 344 & 25 & 49 & 676 & 14 & - \\
\hline \multicolumn{2}{|c|}{ Maple and gray birch, } & 1,419 & 602 & 104 & 86 & 2,211 & 46 & - \\
\hline Pitch pine, & - & - & - & 18 & - & 18 & 20 & \\
\hline Total, . & $\cdot$ & 2,180 & 1,548 & 675 & 430 & 4,833 & - & - \\
\hline Percentage, . & $\cdot$ & 45 & 32 & 14 & 9 & - & 100 & 46 \\
\hline \multicolumn{6}{|c|}{ Ton-Forest TrPes. } & 3,032 & - & 28 \\
\hline Open pasture, & - & . & - & - & . & 1,634 & - & 15 \\
\hline Brush pasture, & - & - & . & . & $\cdot$ & 559 & - & 5 \\
\hline \multicolumn{2}{|c|}{ Business, residential, etc., } & - & - & - & . & 362 & - & 3 \\
\hline Water, · & . & - & . & - & .1 & 332 & - & 3 \\
\hline \multicolumn{2}{|c|}{ Total area of town,. } & - & . & - & $\cdot 1$ & 10,752 & - & 100 \\
\hline
\end{tabular}

\section{New Braintree.}

The woodland of New Braintree is not an important part of its assets. The chestnut type occupies the largest area and is the most important commercially. Pine is not as common as 
in surrounding towns, and is found largely in the Ware River valley section. There is considerable chestnut of commercial size.

There are no wood-using industries in the town and no sawmills. Ties are the chief forest product, and New Braintree depot is an important tie-shipping station for the surrounding country. James Barr \& Son are the leading lumbermen in the town, although operators living in North Brookfield and Ware do most of the lumbering in this vicinity.

Land Types.

\begin{tabular}{|c|c|c|c|c|c|c|c|c|c|}
\hline & & & \multicolumn{4}{|c|}{ Approximate Size Classes. } & \multirow{2}{*}{ Total. } & \multicolumn{2}{|c|}{ Per Cent. } \\
\hline & & & 4 & 3 & 2 & 1 & & Forest. & Town. \\
\hline \multicolumn{3}{|c|}{ Forest TyPES. } & Acres. & Acres. & Acres. & Acres. & Acres. & \multirow{3}{*}{26} & \multirow{3}{*}{ - } \\
\hline Chestnut, . & & $\cdot$ & 151 & 404 & 341 & 297 & $1 ; 193$ & & \\
\hline Oak, . . . & . & $\cdot$ & 63 & - & - & - & 63 & & \\
\hline Chestnut and oa & c, . & $\cdot$ & 442 & 284 & - & 25 & 751 & 15 & - \\
\hline White pine, & - &. & 189 & 310 & 83 & 126 & 708 & 14 & - \\
\hline \multicolumn{3}{|c|}{ Hardwoods and white pine, 1} & 360 & 454 & 88 & 69 & 971 & 20 & - \\
\hline \multirow{2}{*}{\multicolumn{3}{|c|}{$\begin{array}{l}\text { Maple and gray birch, } \\
\text { Softwoods other than white } \\
\text { pine. }\end{array}$}} & 410 & 575 & 32 & 51 & 1,068 & 22 & - \\
\hline & & & 69 & 88 & - & - & 157 & 3 & - \\
\hline Total, . . & . & & 1,684 & 2,115 & 544 & 568 & 4,911 & - & - \\
\hline Percentage, . & - & $\cdot$ & 34 & 43 & 11 & 12 & - & 100 & 36 \\
\hline \multicolumn{7}{|c|}{ NON-FOREST TYPES. } & 3,591 & - & 26 \\
\hline Open pasture, & - & - & - & - & - & . & 4,753 & - & 35 \\
\hline Brush pasture, & - & - & - & - & - & $\cdot$ & 430 & \multirow{2}{*}{-} & \multirow{2}{*}{3} \\
\hline Water, . . & . & - & - & - & - & $\cdot$ & 12 & & \\
\hline \multicolumn{3}{|c|}{ Total area of town, . } & . & . & . & .1 & 13,697 & - & 100 \\
\hline
\end{tabular}

1 Hardwoods are principally maple and birch, with a little chestnut and oak.

\section{Norti Brookfield.}

The woodland of North Brookfield is made up chiefly of second-growth hardwoods. Chestnut forms a less important timber tree than was the case in Warren and West Brookfield, i.e., there are less pure stands. Pine is perhaps the most important species. There are sereral wood lots in the east and west, where young pine trees are growing very vigorously. 
Poplar, although not abundant, is found generally throughout the town. In the northwest, near Sucker Brook, there is a pure stand of hickory of about 10 acres. Other species which make up the forest land are pitch pine, maple, hickory and ash.

There are two lumber dealers and operators in town, William F. Fullam and H. E. Cummings. Both have portable sawmills which operate in the surrounding towns. Mr. Fullam also has a small mill operated by electricity in which he does planing, etc.

Land Types.

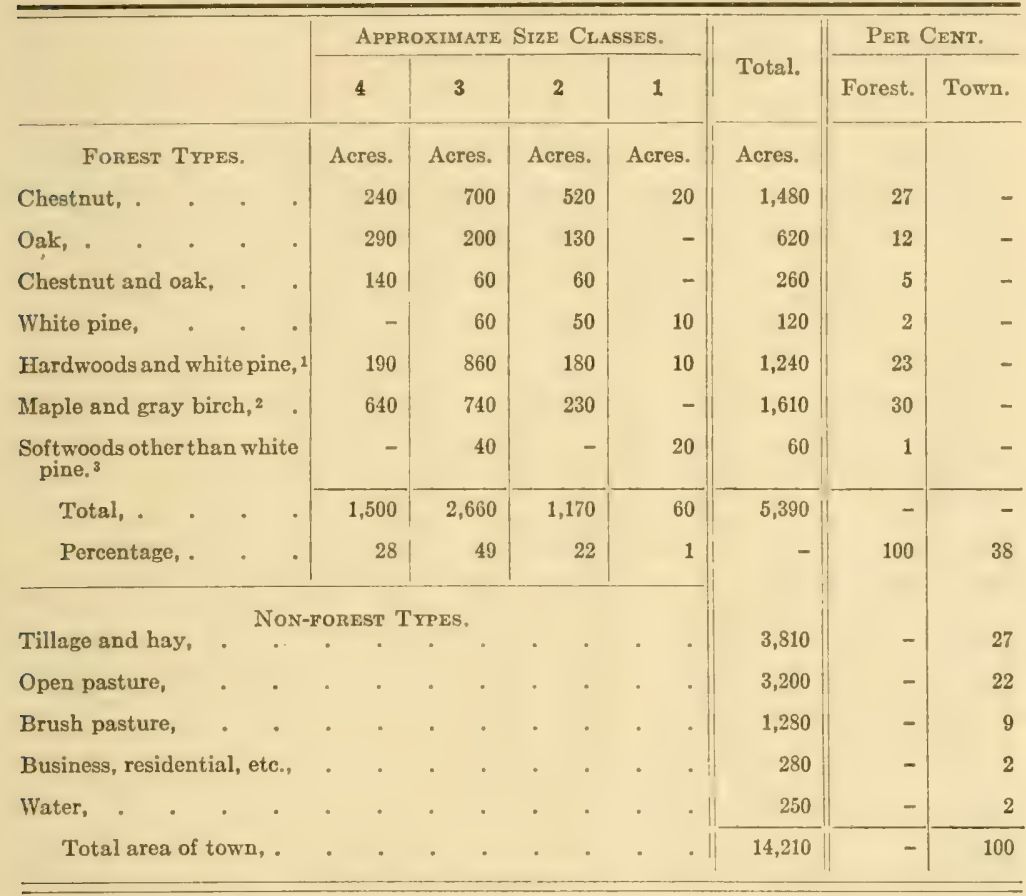

1 Hardwoods are red maple, gray birch, oak and chestnut.

2 This type contains some oak and chestnut.

${ }^{3}$ Mostly pitch pine and hemlock.

\section{Northborodgh.}

The proportion of timbered land to the total area of the town is about 50 per cent. More than half of the high land is wooded, the farms lying mostly in the valleys. There is an abundance of healthy pine, usually in mixed stands, and nearly every wood lot contains at least a small amount. The oak and 
chestnut timber are not in the best of condition. Gypsy and brown-tail moth devastations have been most severe, and are in evidence over the entire area of the town. Tree planting has been practiced on a small scale in at least two instances by citizens. One plantation is located near South Street and the other is owned by a Mr. Wesson. These plantations have reached the large pole stage and are in healthy condition.

Guilford P. Heath cuts from 50 M to $100 \mathrm{M}$ board feet of lumber per year. It is mostly chestnut, with a fair proportion of oak and pine. G. H. Felt, although cutting no timber, buys and sells pine, hemlock, hard pine, eypress, white wood and red cedar, obtaining practically all the stock from outside the State.

Land Types.

\begin{tabular}{|c|c|c|c|c|c|c|c|c|}
\hline & & \multicolumn{4}{|c|}{ Approximate Size Classes. } & \multirow{2}{*}{ Total. } & \multicolumn{2}{|c|}{ Per Cent. } \\
\hline & & 4 & 3 & 2 & 1 & & Forest. & Town. \\
\hline \multicolumn{2}{|c|}{ Forest Types. } & Acres. & Acres. & Acres. & Acres. & Acres. & & \\
\hline Chestnut, . & . & 60 & 520 & 200 & 200 & 980 & 16 & - \\
\hline Oak, . & . & 300 & 830 & 60 & 250 & 1,440 & 23 & - \\
\hline Chestnut and oal- & . & 400 & 640 & 40 & 150 & 1,230 & 20 & - \\
\hline White pine, & $\cdot$ & - & 260 & 80 & 220 & 560 & 9 & - \\
\hline \multicolumn{2}{|c|}{ Hardwoods and white pine, } & 20 & 390 & 50 & 60 & 520 & 8 & - \\
\hline \multirow{2}{*}{\multicolumn{2}{|c|}{$\begin{array}{l}\text { Maple and gray birch, } \\
\text { Softwoods other than white } \\
\text { pine. }\end{array}$}} & 90 & 1,070 & 110 & 60 & 1,330 & 21 & - \\
\hline & & - & 130 & 50 & - & 180 & 3 & - \\
\hline Total, . & - & 870 & 3,840 & 590 & 940 & 6,240 & - & - \\
\hline Percentage, . & . & 14 & 62 & 9 & 15 & - & 100 & 52 \\
\hline \multicolumn{6}{|c|}{ NoN-FOREST TYPES. } & 3,200 & -1 & 27 \\
\hline Open pasture, & . & . & . & . & - & 1,480 & - & 12 \\
\hline Brush pasture, & - & . & - & - & . & 830 & -1 & 7 \\
\hline \multicolumn{2}{|c|}{ Business, residential, etc., } & - & . & - & - & 100 & \multirow{2}{*}{-} & \multirow{2}{*}{2} \\
\hline Water, . & . & • & - & . & $\cdot$ & 200 & & \\
\hline \multicolumn{2}{|c|}{ Total area of town, . } & . & . & . & $\cdot$ & 12,050 & -1 & 100 \\
\hline
\end{tabular}

NoRThbridge.

Very few timber types are found in Northbridge. Chestnut and chestnut and pine are most prominent. In the southwestern part of the town the stands belonging to the Whitin 
Machine Works will run a good average in size, while a fair amount will come under the head of mature merchantable. Scattered throughout the entire town are small patches of chestnut which will run to Class 2, although the majority is slightly smaller. Pine occurs, but not abundantly, in Class 2.

Stands of mixed hardwoods occur in many places. The plots are small and the trees are seldom larger than Class 3. These stands quickly run into chestnut and oak. Oak is very common. It occurs in large areas, generally in Class 3. Birch is not present in large amounts.

The type covering most of the town is a mixture of chestnut and oak sprouts, Class 4, with a stocking varying from 75 to 100 per cent. Where timber larger than Class 3 occurs it is practically always straight and sound, and will furnish excellent material for poles or for the sawmill.

At the time the survey was made there were no sawmills or woodworking industries in Northbridge.

Land Types.

\begin{tabular}{|c|c|c|c|c|c|c|c|}
\hline & \multicolumn{4}{|c|}{ Approximate Size Classes. } & \multirow{2}{*}{ Total. } & \multicolumn{2}{|c|}{ Per Cent. } \\
\hline & 4 & 3 & 2 & 1 & & Forest. & Town. \\
\hline FoREST TYPES. & Acres. & Acres. & Acres. & Acres. & Acres. & & \\
\hline Chestnut, . . & 240 & 280 & 350 & 220 & 1,090 & 15 & - \\
\hline Oak, . . . & 470 & 340 & - & 30 & 840 & 11 & - \\
\hline Chestnut and oak, . & 840 & 290 & 100 & 90 & 1,320 & 18 & - \\
\hline White pine, & 390 & 250 & 100 & 370 & 1,110 & 15 & - \\
\hline Hardwoods and white pine, & 510 & 380 & 130 & 30 & 1,050 & 14 & - \\
\hline Maple and gray birch, & 1,030 & 810 & 100 & - & 1,940 & 26 & - \\
\hline Pitch pine, & - & 10 & 30 & - & 40 & - & - \\
\hline Total, . & 3,480 & 2,360 & 810 & 740 & 7,390 & - & - \\
\hline Percentage, . & 47 & 32 & 11 & 10 & - & 100 & 61 \\
\hline Tillage and hay, . NoN- & FOREST T & YPES. & . & . & 2,060 & - & 17 \\
\hline Open pasture, & . & . & . & . & 990 & - & 8 \\
\hline Brush pasture, & . & . & . & . & 770 & -1 & 6 \\
\hline Brush swamp, & . & . & . & . & 100 & - & 1 \\
\hline Business, residential, etc., & . & . & $\therefore$ & . & 320 & - & 3 \\
\hline Water, . & . & . & . & . & 530 & - & 4 \\
\hline Total area of town, . & . & . & . & . & 12,160 & - & 100 \\
\hline
\end{tabular}




\section{OAKHAM.}

White pine types, either pure pine or mixtures of pine, chestnut and oak, form the largest part of the woodland, and there is a considerable amount of commercial, or nearly commercial, size. Chestnut is second in importance, and is found mostly in the south and west sections of the town. There appears to be more oak in this town than in the surrounding townships, but most of it is of small size and poor quality.

This town has no manufacturing industries of any kind. There is a basket factory in Coldbrook, but it was not running when the survey was made. Ash, hickory and oak were used in this business. There is at present a water mill on Five Mile River belonging to Walter Dean. Mr. Dean formerly bought and operated his own woodlands, but has done little of this business in recent years, and his mill work is confined largely to custom sawing.

Land Types.

\begin{tabular}{|c|c|c|c|c|c|c|c|c|c|}
\hline & & & \multicolumn{4}{|c|}{ Approximate Size Classes. } & \multirow{2}{*}{ Total. } & \multicolumn{2}{|c|}{ Per Cent. } \\
\hline & & & 4 & 3 & 2 & 1 & & Forest. & Town. \\
\hline \multicolumn{3}{|c|}{ Foriest Trpes. } & Acres. & Acres. & Acres. & Acres. & Acres. & & \\
\hline Chestnut, . & . & . & 61 & 257 & 814 & 153 & 1,285 & 15 & - \\
\hline Oak, . & . & . & 373 & 43 & 43 & 43 & 502 & 6 & - \\
\hline Chestnut and oak, & . & $\cdot$ & 349 & 496 & 263 & 110 & 1,218 & 14 & - \\
\hline White pine, & - & $\cdot$ & 349 & 606 & 312 & 514 & 1,781 & 21 & - \\
\hline \multicolumn{3}{|c|}{ Hardwoods and white pine, 1} & 716 & 1,199 & 202 & 153 & 2,270 & 27 & - \\
\hline Maple and birch. & . & . & 594 & 569 & 135 & - & 1,298 & 15 & - \\
\hline Pitch pine, & . & $\cdot$ & 12 & 122 & 37 & 37 & 208 & 2 & . - \\
\hline Total, . & . & .1 & 2,454 & 3,292 & 1,806 & 1,010 & 8,562 & -1 & - \\
\hline Percentage, . & - & $\cdot$ & 29 & 38 & 21 & 12 & -1 & 100 & 63 \\
\hline Tillage and hay, & . & Non-1 & FOREST T & YPES. & . & $\cdot$ & 1,995 & - & 15 \\
\hline Open pasture, & - & . & : & . & - & $\cdot 1$ & 2,062 & - & 15 \\
\hline Brush pasture, & . & - & . & . & . & $\cdot 1$ & 685 & -1 & 5 \\
\hline Water, . . & . & . & - & . & . & $\cdot \mid$ & 281 & -1 & 2 \\
\hline \multicolumn{3}{|c|}{ Total area of town,. } & . & $\because$ & - & $\cdot$ & 13,585 & - & 100 \\
\hline
\end{tabular}

1 Hardwoods are chestnut, oak and birch. 


\section{OXFORD.}

Most of the forest land is found on the hills, those to the west being more generally forested than those on the east side. The largest individual types are the gray birch and maple, but the most prominent trees are chestnut and pine. There is a rather unusual amount of forest land, with a growth of commercial, or nearly commercial, size. In the non-forest type one is struck by the small amount of open and brush pasture as compared with tillage.

The principal wood-using industry of Oxford is the box factory of Chaffee Brothers. In addition to boxes they manufacture rough building lumber and planing mill products. They operate two or three portable mills, cutting lots in southern Worcester County and northern Connecticut, although occasionally they have operated wood lots as far away as New Hampshire and Maine. They handle more or less chestnut, which is either put into building lumber or ties. Their annual consumption of lumber is about 5,000,000 feet.

Turner Brothers make a specialty of dealing in chestnut, especially for ties.

Land Types.

\begin{tabular}{|c|c|c|c|c|c|c|c|c|c|}
\hline & & & \multicolumn{4}{|c|}{ Approximate Size Classes. } & \multirow{2}{*}{ Total. } & \multicolumn{2}{|c|}{ Per Cent. } \\
\hline & & & 4 & 3 & 2 & 1 & & Forest. & Town. \\
\hline \multicolumn{3}{|c|}{ Forest Types. } & Acres. & Acres. & Acres. & Acres. & \multirow{2}{*}{$\begin{array}{r}\text { Acres. } \\
4450\end{array}$} & \multirow[b]{2}{*}{4} & \multirow[b]{2}{*}{ - } \\
\hline Chestnut, . & - & . & 20 & 40 & 250 & 140 & & & \\
\hline Oak, . . & . & . & 290 & 130 & - & - & 420 & 4 & - \\
\hline Chestnut and oak, & $\therefore$ & . & 1,030 & 650 & 440 & 20 & 2,140 & 19 & - \\
\hline & : &. & 290 & 280 & 400 & 580 & 1,550 & 14 & - \\
\hline \multicolumn{3}{|c|}{$\begin{array}{l}\text { White pine, } \\
\text { Hardwoods and white pine, }\end{array}$} & 510 & 1,230 & 490 & 860 & 3,090 & 28 & - \\
\hline \multicolumn{3}{|c|}{ Mixed hardwoods, ${ }^{2}$} & 1,450 & 1,210 & 330 & 450 & 3,440 & \multirow[b]{2}{*}{31} & \multirow[b]{2}{*}{ - } \\
\hline \multicolumn{3}{|c|}{$\begin{array}{l}\text { Softwoods other than white } \\
\text { pine. }\end{array}$} & - & 40 & - & - & 40 & & \\
\hline Total, . & . & $\cdot 1$ & 3,590 & 3,580 & 1,910 & 2,050 & 11,130 & - & - \\
\hline Percentage, . & . &. & 32 & 32 & 17 & 19 & - & 100 & 64 \\
\hline \multicolumn{7}{|c|}{ NON-FOREST TrPES. } & & & \\
\hline Tillage and hay, & - & . & $\cdot \quad \cdot$ & $\therefore$. & . & - & 4,470 & - & 26 \\
\hline Open pasture, & . & . & . & $\because$ & . & . & 730 & - & 4 \\
\hline Brush pasture, & - & - & - & . & . & - & 600 & - & 3 \\
\hline Water, . & - & - & - & - & . & - & 600 & - & 3 \\
\hline \multicolumn{3}{|c|}{ Total area of town,. } & - & . & - & $\cdot$ & 17,530 & - & 100 \\
\hline
\end{tabular}

1 Hardwoods are principally chestnut and oak.

2 Gray birch and red maple in smaller classes, and chestnut and oak in the larger sizes. 


\section{Paxton.}

About 60 per cent. of Paxton is wooded, chestnut and white pine being the leading species. Oak and soft maple occur abundantly, and thick stands of young birch are found everywhere. Practically all of the timber in the eastern part of the town is below Class 2 in size. The best stand found was a mixture of pine and chestnut near the southern boundary of the town, one-half mile east of Kicttell Brook. This is in splendid condition and ranges from Class 2 to Class 1 in size. Very small stands of pine of this class are found in scattered wood lots. Mixed hardwoods, common to low situations, are present in many places. In general, such stands are in rather poor condition. Tangled undergrowth and young dead trees are characteristic, and laurel is very common.

Edward E. Eames, Paxton, owns a water mill. He buys small wood lots and cuts timber. He has a number of wood lots well stocked with pine and chestnut, now too small to cut. He has done a little planting of white pine.

D. T. Grayton owns no mill, but buys wood lots and installs portable mills. In good years he cuts about 1,000 M board feet of pine, chestnut and hemlock. There are no woodworking industries in Paxton.

Land Types.

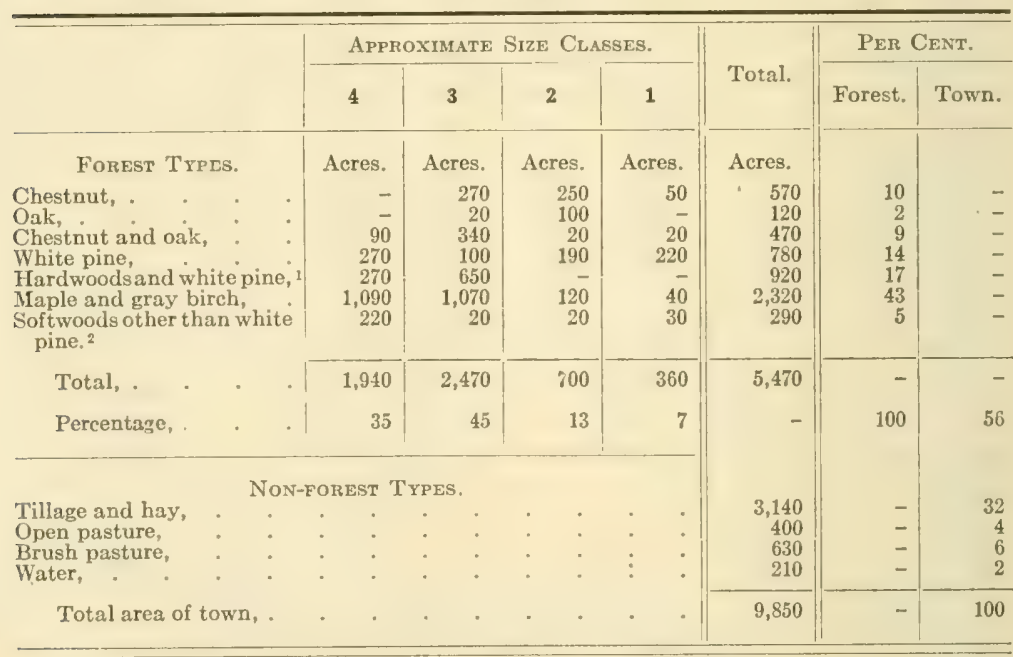

1 Hardwoods are gray birch, red maple and oak.

2 Pitch pine, hemlock and spruce. 


\section{Petersham.}

This town has an unusually large percentage of pine, especially in the medium sizes, forming a large part of the large percentage of forest area which the town has. The second largest type, called maple and birch, which in most towns means red maple and gray birch, in this section includes also white and yellow birch, beech and sugar maple. There is an unusual amount of hemlock in the forests of Petersham. There is a rather high percentage of Class 2, which may be due to the fact that nearly 2,000 acres of the best timberland in the town is in the possession of the Harvard Forest School.

There is no manufacturing industry whatever in the town. The town obtains its livelihood from farming and catering to summer residents, for it is a popular summer resort. There is a small box shop belonging to John Carter and a water-power sawmill at Nichewaug, but neither is running at present. There is a ready market for pine and other lumber in Athol. The Diamond Match Company has now a portable mill operating in the town, while each winter the authorities in charge of the Forest School do some operating. There is a fair market for cordwood, but it is limited in extent.

Land Types.

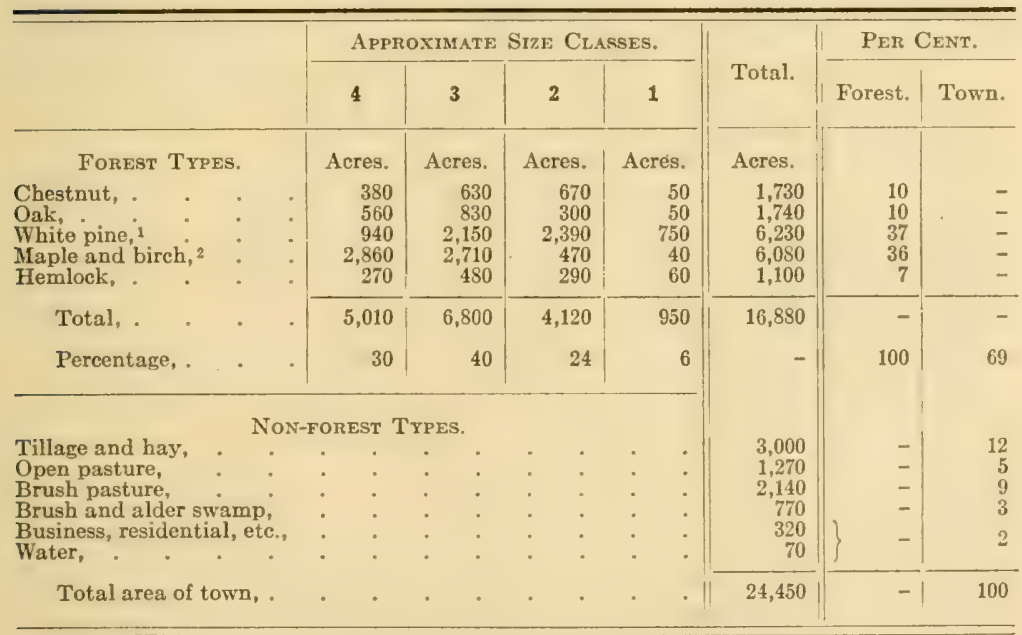

1 White pine in mixture has been proportioned as if growing in pure stands.

2 Smaller sizes are red maple and gray birch, while larger size classes contain white and yellow birch and beech. 


\section{Phillipston.}

There are but a few good stands of timber left in Phillipston. Possibly the best of these lies on the ridge west of Queen Lake or Phillipston Pond. There is also a fairly good stand of white pine and mixed hardwoods - oak, chestnut, birch and maple on the ridge which forms the eastern border of the lake.

Aside from the above-mentioned stands most of the forested lands of Phillipston consist of pure white pine stands and coppice hardwoods, together with mixed stands of white pine and hardwoods, which are of the reproduction and small merchantable size. Chestnut was found occasionally in pure stands, but in most cases it was mixed with oak and maple. Oak was found more frequently in pure stands than was the chestnut.

The principal species found, in order, are white pine, oak, maple, chestnut, gray birch, white birch, spruce, larch, hemlock and a little yellow birch. Basswood was noticed in many places, but this existed only in the reproduction size. Ash also appeared in small quantities.

On account of the scarcity of good timber there are no woodworking industries in the town.

Land Types.

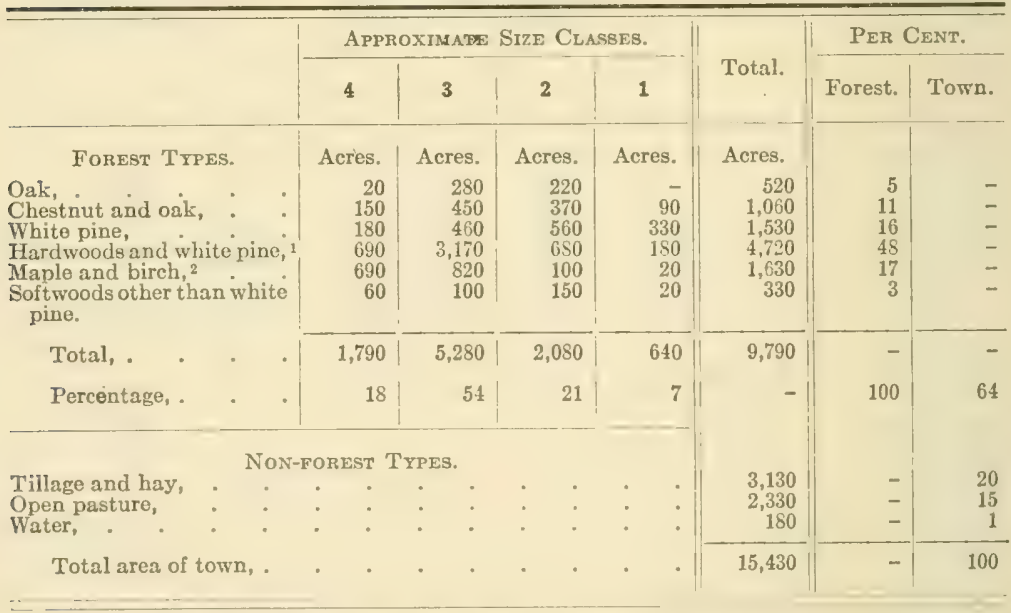

1 Hardwoods are gray birch, soft maple, oak and chestnut.

2 Principally gray birch and red maple, with some white and yellow birch and beech in the larger sizes. 


\section{Princeton.}

Woodlands show little variation either in composition or size classes over most of the area. The gray birch and maple types cover the largest area. White pine is generally found in mixture with hardwoods, although there are many small scattering wood lots which contain almost pure stands. Chestnut and oak are usually found in mixture together. The chestnut, however, is often found in pure well-distributed stands; but the oak, when separate from the chestnut, usually contains a mixture of maple and yellow and paper birch.

The Roper Lumber and Box Company is the only mill and woodworking industry in Princeton. It is located very close to the IIubbardston line. This mill has an average cut of about 1,000,000 board feet. Pine, hemlock and spruce constitute about nine-tenths of the annual cut, while mixed hardwoods make up the remainder.

\section{Land Types.}

\begin{tabular}{|c|c|c|c|c|c|c|c|}
\hline & \multicolumn{4}{|c|}{ Approximate Size Classes. } & \multirow{2}{*}{ Total. } & \multicolumn{2}{|c|}{ Per Cent. } \\
\hline & 4 & 3 & 2 & 1 & & Forest. & Town. \\
\hline $\begin{array}{l}\text { Fonest Trpes. } \\
\text { Chestnut, } \\
\text { Oak, } \\
\text { Chestrut and oak, } \\
\text { White pine, } \\
\text { Hardwoods and white pine, } \\
\text { Maple and gray birch, } \\
\text { Softwoods other than white } \\
\text { pine. }\end{array}$ & $\begin{array}{r}\text { Acres. } \\
100 \\
310 \\
340 \\
290 \\
1,300 \\
2,350\end{array}$ & $\begin{array}{r}\text { Acres. } \\
980 \\
550 \\
840 \\
1,000 \\
1,470 \\
1,220 \\
80\end{array}$ & $\begin{array}{r}\text { Acres. } \\
610 \\
430 \\
270 \\
730 \\
30 \\
250 \\
170\end{array}$ & $\begin{array}{r}\text { Acres. } \\
120 \\
40 \\
- \\
850 \\
90 \\
80 \\
10\end{array}$ & $\begin{array}{r}\text { Acres. } \\
1,810 \\
1,330 \\
1,450 \\
2,870 \\
3,120 \\
3,900 \\
260\end{array}$ & \begin{tabular}{r|r}
12 \\
9 \\
10 \\
20 \\
21 \\
26 \\
2
\end{tabular} & - \\
\hline Total, . . & 4,920 & 6,140 & 2,490 & 1,190 & 14,740 & - & - \\
\hline Percentage, . & 33 & 42 & 17 & 8 & - & 100 & 65 \\
\hline $\begin{array}{l}\text { Tillage and hay, } \\
\text { Open pasture, } \\
\text { Brush pasture, } \\
\text { Water, }\end{array}$ & $\begin{array}{l}\text { OREST T } \\
\vdots \\
\vdots\end{array}$ & $\vdots:$ & : & : & $\begin{array}{r}2,610 \\
4,800 \\
410 \\
290\end{array}$ & $\begin{array}{l}z \\
z \\
z\end{array}$ & $\begin{array}{r}11 \\
21 \\
2 \\
1\end{array}$ \\
\hline Total area of town, . & . & . & . & . & 22,850 & - & 100 \\
\hline
\end{tabular}

\section{ROYALSTON.}

Royalston has but two or three stands of virgin growth left. These are white pine and hemlock on Jacob's Hill. The hardwood stands are of coppice growth, while the white pine stands seeded in naturally. The principal trees found in order of im- 
portance and quantity are white pine, hemlock, chestnut, oak, maple (rock and red), white birch, yellow birch, beech, spruce, ash, larch, gray birch, red elm and ironwood.

Royalston has no wood-using industries. It has four sawmills cutting white pine, chestnut, oak, hemlock, maple, birch and beech.

W. Farrar at South Royalston has a small mill cutting from $100 \mathrm{M}$ to $500 \mathrm{M}$ board feet per year.

Newton \& Davis in the northeastern part of the town cut $1,000 \mathrm{M}$ board feet per year.

C. Perry in the northern part cuts $200 \mathrm{M}$ board feet per year, most of which is baled stock.

G. E. Pierce has done some cutting in the western part of the town.

The daily capacity of these mills is about $8 \mathrm{M}$ board feet. They do not work steadily on account of a shortage of labor.

Land Types.

\begin{tabular}{|c|c|c|c|c|c|c|c|c|c|}
\hline & & & \multicolumn{4}{|c|}{ Approximate Size Classes. } & \multirow{2}{*}{ Total. } & \multicolumn{2}{|c|}{ Per Cfint. } \\
\hline & & & 4 & 3 & 2 & 1 & & Forest. & Town. \\
\hline \multicolumn{3}{|c|}{ Forest Types. } & Acres. & Acres. & Acres. & Acres. & Acres. & & \\
\hline Chestnut, . & & . & 70 & 130 & 180 & 20 & 400 & 2 & - \\
\hline Oak, . & & . & 160 & 290 & 240 & 120 & 810 & 4 & - \\
\hline Chestnut and oak & . & . & 70 & 100 & 190 & 90 & 450 & 2 & - \\
\hline White pine, & . & . & 280 & 1,480 & 1,570 & 880 & 4,210 & 20 & - \\
\hline \multicolumn{3}{|c|}{ Hardwoods and white pine, 1} & 2,530 & 2,160 & 660 & 20 & 5,370 & 25 & - \\
\hline \multicolumn{3}{|l|}{ Mixed hardwoods, ${ }^{2}$} & 3,000 & 2,800 & 1,410 & 520 & 7,730 & 37 & - \\
\hline \multicolumn{3}{|c|}{$\begin{array}{l}\text { Softwoods other than white } \\
\text { pine. }{ }^{3}\end{array}$} & 310 & 880 & 620 & 310 & 2,120 & 10 & - \\
\hline Total, . & & . & 6,420 & 7,840 & 4,870 & 1,960 & 21,090 & - & - \\
\hline Percentage, . & & - & 31 & 37 & 23 & 9 & - & 100 & 75 \\
\hline \multicolumn{7}{|c|}{ Tillage and hay NoN-FOREST TrPes. } & 3,620 & - & 13 \\
\hline Open pasture, & $\cdot$ & - & $\cdot$ & • & - & $\cdot$ & 1,990 & - & 7 \\
\hline Brush pasture, & · & . & . & - & . & · & 1,020 & - & 4 \\
\hline \multicolumn{3}{|c|}{ Business, residential, etc., } & - & . & . & $\cdot$ & 70 & \multirow{2}{*}{-} & \multirow{2}{*}{1} \\
\hline Water, . & - & . & . & - & - & - & 180 & & \\
\hline \multicolumn{3}{|c|}{ Total area of town, . } & - & . & . & . & 27,970 & - & 100 \\
\hline
\end{tabular}

\footnotetext{
1 Hardwoods are principally soft maple and gray birch, but some white birch and hard maple are represented in the larger classes.

2 Mostly soft maple and gray birch, with some white birch, beech and sugar maple, especially in Classes 2 and 1.

3 Mostly hemlock, with some spruce and larch.
} 


\section{Rutland.}

White pine is the leading tree, and the remainder of the woodland is made up of oak, chestnut, soft maple and birch, with small amounts of hemlock and spruce. White pine and birch is the leading type. Practically the entire northern quarter of the town is covered with this growth. The pine, in almost every case, is in very healthy condition, and has a good start on the birch. While birch is now present in large quantities, all conditions point to its suppression. In ten to twenty years this should be pure pine forest. Very little farm land is found in this section. The pine runs in size from Class 4 to Class 2. In the southern half of the town the composition is more varied. On the higher lands white pine, chestnut and oak predominate. In the lower portions soft maple and alder, with small amounts of hemlock and spruce, are found. Mixtures of soft maple and alder are very common. Trees of every size class are found, but the average is about Class 3. South of Demond Pond for three-quarters of a mile are stands of excellent chestnut. These trees average Class 2 in size. About 60 per cent. of the town is covered with wood growth.

John Moore of Ware has set up a portable mill in the southwest corner of the town, capable of sawing about $300 \mathrm{M}$ board feet. He cuts chestnut mostly, with some oak and pine.

Daniels Worsted Mills, West Rutland, owns, in connection with the worsted mill, a permanent sawmill. This is used only when logs are brought in by farmers from time to time. Any kind of wood is sawed, but mostly chestnut and pine. This mill cuts about 50,000 board feet per year. 
Land Types.

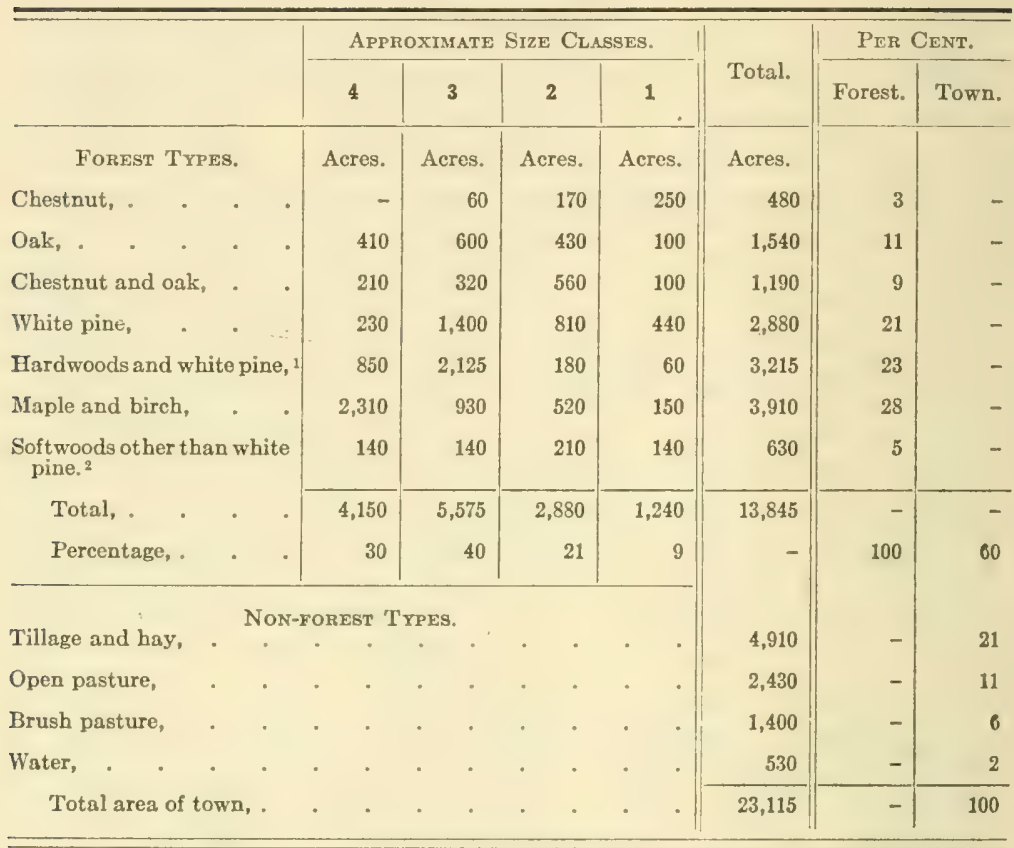

1 Hardwoods are maple, birch and oak.

2 About 30 per cent. pitch pine; remainder, hemlock and larch.

\section{SHREwsBURy.}

About 50 per cent. of Shrewsbury is wooded. Small wood lots of from 10 to 25 acres, alternating with farm and pasture lands, are distinctly characteristic of the eastern three-quarters of the town. Chestnut in pure stands and in mixture with oak forms the larger part of the wood lots. In size the trees will range from Class 4 to Class 1 . Birch occurs in numerous areas, though not in exceptionally large ones. The best timber in the town is found in the vicinity of Lake Quinsigamond. This is in perfect condition, and to a large extent falls in Class 1 . It is made up mostly of chestnut in pure stands and in mixture with white pine.

Harlow Hill, in the northwestern part of the town, comprising roughly an area of 2 square miles, is completely covered with chestnut and pine, all size classes being represented. The 
greater part is a sprout growth of Classes 4 to 3 , stocked to a full 100 per cent. Pine and chestnut of Class 2 and better occur in large amounts on the north side of the hill.

There are no woodworking industries in town.

Land Types.

\begin{tabular}{|c|c|c|c|c|c|c|c|c|c|}
\hline & & & \multicolumn{4}{|c|}{ Approximate Size Classes. } & \multirow{2}{*}{ Total. } & \multicolumn{2}{|c|}{ Per Cent. } \\
\hline & & & 4 & 3 & 2 & 1 & & Forest. & Town. \\
\hline \multicolumn{3}{|c|}{ Forest TyPES. } & Acres. & Acres. & Acres. & Acres. & Acres. & & \multirow{8}{*}{$\begin{array}{l}- \\
- \\
- \\
-\end{array}$} \\
\hline Chestnut, . & - & - & 250 & 260 & 950 & 400 & 1,860 & 27 & \\
\hline Oak, . . . & - & . & - & 220 & 160 & 60 & 440 & 6 & \\
\hline Chestnut and oak & . & . & 620 & 330 & 230 & 100 & 1,280 & 19 & \\
\hline White pine, & - & . & 30 & 100 & 40 & 30 & 200 & \multirow{2}{*}{39} & \\
\hline \multicolumn{3}{|c|}{ Hardwoods and white pine, 1} & 150 & 190 & 40 & - & 380 & & \\
\hline Maple and birch, & - & $\cdot$ & 1,530 & 920 & 190 & 20 & 2,660 & \multirow{2}{*}{39} & \\
\hline Pitch pine, & - & - & 15 & 15 & - & - & 30 & & \\
\hline Total, & $\cdot$ & $\cdot$ & 2,595 & 2,035 & 1,610 & 610 & \multirow{2}{*}{$\begin{array}{r}6,850 \\
-\end{array}$} & \multirow{2}{*}{$\begin{array}{r}- \\
100\end{array}$} & \multirow{2}{*}{$\begin{array}{r}- \\
49\end{array}$} \\
\hline Percentage, . & - & $\cdot$ & 38 & 29 & 23 & 10 & & & \\
\hline \multicolumn{7}{|c|}{ NON-FOREST TYPES. } & 3,690 & - & 26 \\
\hline Open pasture, & . & - & - & - & - & - & 1,880 & - & 14 \\
\hline Brush pasture, & . & - & . & . & . & $\cdot$ & 860 & - & 6 \\
\hline Water, . & . & . & . & - & - & . & 690 & - & 5 \\
\hline Total area of $t$ & town, & . & - & . & - & $\cdot$ & 13,970 & - & 100 \\
\hline
\end{tabular}

1 Hardwoods are principally red maple, chestnut and oak.

\section{Southborough.}

Gray birch and maple is the most common type, occurring mostly in small cordwood sizes. The chestnut and oak type and the white pine type are the most important. There are several stands containing good-sized trees of both of these types.

Marlborough, situated about 4 miles from Southborough, supplies this town by railroad and auto-truck service with all of its lumber and wood. 
Land Types.

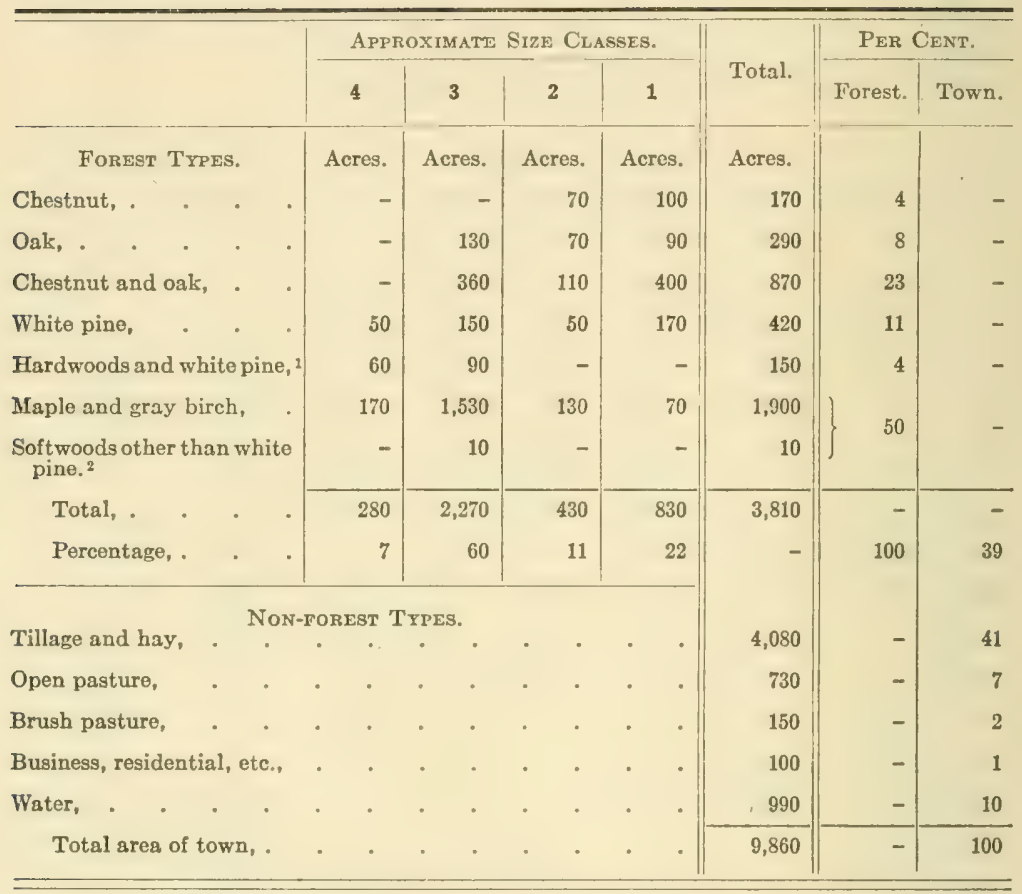

1 Hardwoods are red maple, gray birch, chestnut, red oak and poplar.

2 Mostly pitch pine.

\section{SOUTHBRIDGE.}

The largest individual type is the gray birch and red maple, either mixed or in pure stands. Commercially speaking, both pine and chestnut are of about equal importance, but there is comparatively little growth of merchantable size in either type. There is an unusual amount of hickory in the town, although most of it is of small size. Considerable amounts of native lumber are used in town for the manufacture of boxes and sash and doors. The following concerns are interested in the lumber business in Southbridge:-

Clemence Associates, boxes, sash, blinds and building lumber.

Ide Lumber Company, building lumber, sash and doors.

Charles Hyde, boxes.

Charles M. Morse, operator, principally chestnut ties and poles. 
Land Types.

\begin{tabular}{|c|c|c|c|c|c|c|c|}
\hline & \multicolumn{4}{|c|}{ Approximate Size Classeg. } & \multirow{2}{*}{ Total. } & \multicolumn{2}{|c|}{ Per Cent. } \\
\hline & 4 & 3 & 2 & 1 & & Forest. & Town. \\
\hline FOREST TYPES. & Acres. & Acres. & Acres. & Acres. & Acres. & & \\
\hline Chestnut, . . . & 380 & 360 & 250 & 30 & 1,020 & 13 & - \\
\hline Oak, . . . . & 670 & 610 & 140 & 20 & 1,440 & 19 & - \\
\hline Hickory, . & 240 & 220 & 40 & - & 500 & 7 & - \\
\hline White pine, & 250 & 750 & 410 & 210 & 1,620 & 21 & - \\
\hline Maple and birch, . & 1,780 & 930 & 90 & 20 & 2,820 & 37 & - \\
\hline $\begin{array}{l}\text { Softwoods other than white } \\
\text { pine. }\end{array}$ & 20 & 110 & 90 & 20 & 240 & 3 & - \\
\hline Total, . . & 3,340 & 2,980 & 1,020 & 300 & 7,640 & - & - \\
\hline Percentage, . & 44 & 39 & 13 & 4 & - & 100 & 57 \\
\hline Tillage and hay, . Nox & FREST T & XPES. & . & . & 2,410 & - & 18 \\
\hline Open pasture, & . & . & . & . & 800 & - & 6 \\
\hline Brush pasture, . & . & . & . & $\cdot$ & 940 & - & 7 \\
\hline Alder and brush swamp, & . & . & . & . & 420 & - & 3 \\
\hline Business, residential, etc., & . & . & . & . & 1,000 & - & 8 \\
\hline Water, . . & . & . & . & . & 100 & - & 1 \\
\hline Total area of town, . & . & . & . & . & 13,310 & - & 100 \\
\hline
\end{tabular}

\section{SPENCER.}

Most of the southern half of Spencer is wooded, the chief species being white pine, chestnut, oak and birch, the amounts of these being in the order named, from most abundant to least. The timber is standing now in excellent condition, although not much of merchantable size is found. Portable mills have been working in at least five distinct areas within the last few years, and have made extensive clearings in various parts of the town. The best timber will be found in the south central, southwestern and the eastern edge of the town. Chestnut and pine are the only two species present of merchantable size, and these seldom range higher than Class 2.

No permanent sawmills were in operation at the time the survey was made, but portables have been at work almost constantly during the past few years. Mr. W. A. Wilson is 
probably the leading operator in the town, cutting from 500 to 1,000 M board feet per year. Pine is cut almost entirely, there being very little chestnut of merchantable size.

Land Types.

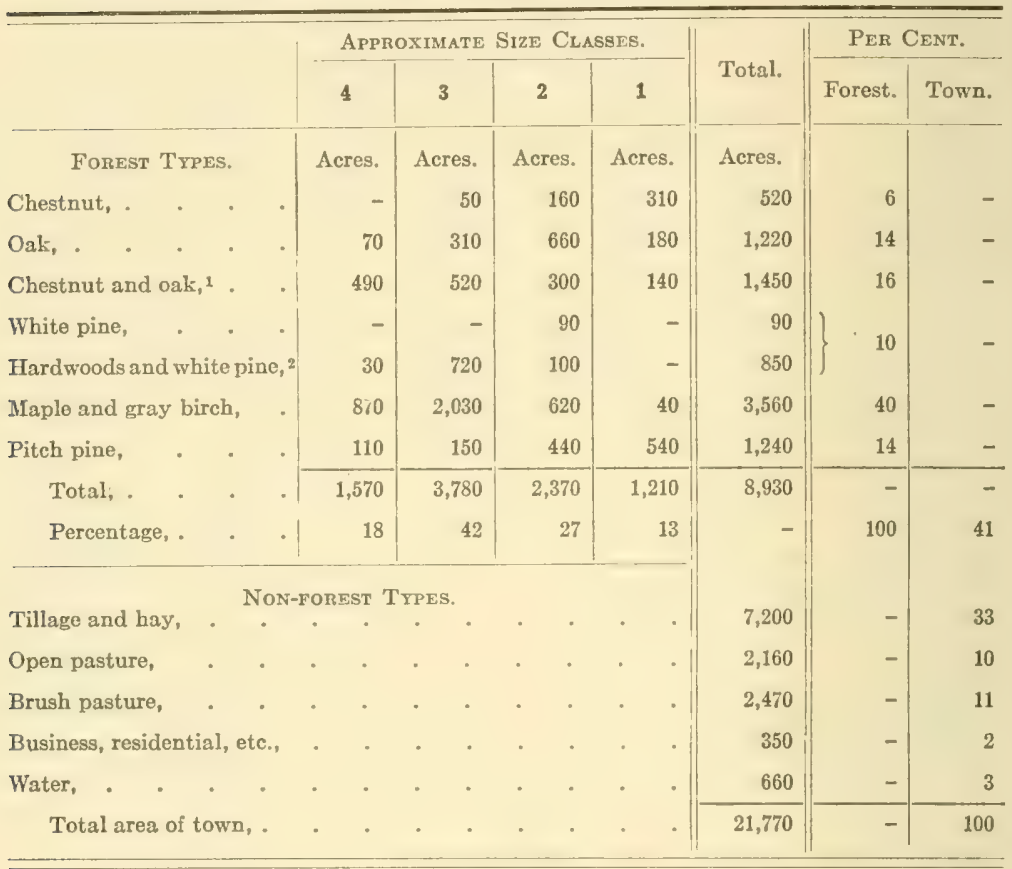

1 Chestnut greatly predominating. $\quad 2$ Hardwoods are largely red maple and birch.

\section{Sterling.}

The majority of the timber in Sterling is in excellent condition and growing rapidly, with the exception of the blightinfested chestnuts. Pine, pine and chestnut, pure chestnut, chestnut sprout growth, gray birch and birch and pine are the types most often found. The amounts of soft maple and other mixed hardwoods are very small when compared with these other types. Size classes range from reproduction to size 1, this latter being found only in small scattered lots. Pure pine and pine and chestnut are the trees generally found in such size classes.

The wooded portion covers about 50 per cent. of the town's area. The percentage of open country is much greater in the eastern two-thirds of the town, but in the west and northwest 
the percentage of timber will run about 70 per cent. It is characteristic that where timber occurs the stocking will generally run complete.

The Sterling Lumber Company buys wood lots of varying size, installs portable mills, and after cutting the timber disposes of the land. There are no permanent mills working at the present time in Sterling. Pine and chestnut are cut in largest quantities, with small amounts of oak and other hardwoods. During the season of 1912-13 the amount cut was 2,000,000 board feet. This was taken from Sterling and surrounding towns.

There is a chair factory in the town, owned and operated by Edwin Stevenson. This factory uses practically all of the native woods, requiring about $200 \mathrm{M}$ 'board feet per year. A small mill is run in connection with the factory.

Messrs. T. and E. R. Buck also operate a chair factory in town. They use practically every kind of lumber in the manufacture of their product.

Land Types.

\begin{tabular}{|c|c|c|c|c|c|c|c|}
\hline & \multicolumn{4}{|c|}{ Approximate Size Clas8es. } & \multirow{2}{*}{ Total. } & \multicolumn{2}{|c|}{ Per Cent. } \\
\hline & 4 & 3 & 2 & 1 & & Forest. & Town. \\
\hline FOREST TrPes. & Acres. & Acres. & Acres. & Acres. & Acres. & & \\
\hline Chestnut, . & 70 & 410 & 840 & 200 & 1,520 & 16 & - \\
\hline Oak, . . & 240 & 330 & 40 & - & 610 & 6 & - \\
\hline Chestnut and oak, . & 810 & 1,110 & 590 & 110 & 2,620 & 27 & - \\
\hline White pine, . . & 730 & 590 & 270 & 60 & 1,650 & 17 & - \\
\hline Hardwoods and white pine, 1 . & 290 & 690 & 90 & - & 1,070 & 11 & - \\
\hline Maple and gray birch, . & 1,120 & 780 & 290 & $4^{-}$ & 2,190 & 22 & - \\
\hline $\begin{array}{l}\text { Softwoods other than white } \\
\text { pine. } 2\end{array}$ & 30 & - & 20 & 60 & 110 & 1 & - \\
\hline Total, . & 3,290 & $\overline{3,910}$ & 2,140 & 430 & 9,770 & - & - \\
\hline Percentage, . & 34 & 40 & 22 & 4 & - & 100 & 49 \\
\hline Tillage and hay, . NoN- & FOREST T & rTES. & . & . & 4,932 & - & 25 \\
\hline Open pasture, & . & . & . & . & 4,230 & - & 21 \\
\hline Brush pasture, . & . & . & . & . & 460 & - & 2 \\
\hline Business, residential, etc., & . & . & . & . & 60 & 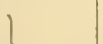 & \\
\hline Water, . . & . & . & . & . & 560 & - & 3 \\
\hline Total area of town, . & . & . & . & . & 20,012 & - & 100 \\
\hline
\end{tabular}

1 Hardwoods are largely gray birch and red maple.

2 Pitch pine and hemlock. 


\section{STURBRIDGE.}

The largest individual type is gray birch and maple closely followed by oak. Chestnut and pine are not such prominent types as they are in neighboring towns, due to the fact that the town has been heavily logged for these species in recent years. For the same reason there is a dearth of larger size classes.

There are no wood-using industries in the town, and most of the logging is done by operators from Southbridge and Oxford. George Wright is the owner of a sawmill.

Land Types.

\begin{tabular}{|c|c|c|c|c|c|c|c|}
\hline & \multicolumn{4}{|c|}{ Approximate Size Classes. } & \multirow{2}{*}{ Total. } & \multicolumn{2}{|c|}{ Per Cent. } \\
\hline & 4 & 3 & 2 & 1 & & Forest. & Town.: \\
\hline Fonest Trpes. & Acres. & Acres. & Acres. & Acres. & Acres. & & \\
\hline Chestnut, . . & 160 & 140 & 460 & 60 & 820 & 5 & - \\
\hline Oak, . . . & 1,990 & 1,870 & 380 & - & 4,240 & 27 & - \\
\hline Chestnut and oak, . & 420 & 390 & 100 & - & 910 & 6 & - . \\
\hline White pine, & 270 & 780 & 650 & 220 & 1,920 & 12 & - \\
\hline Hardwoods and white pine, & 1,090 & 1,090 & 220 & - & 2,400 & 15 & - \\
\hline Maple and birch, & 3,460 & 1,350 & 260 & - & 5,070 & 32 & - \\
\hline Hemlock, . & 70 & 280 & 160 & 20 & 530 & 3 & - \\
\hline Total, & 7,460 & 5,900 & 2,230 & 300 & 15,890 & - & - \\
\hline Per centage, . & 47 & 37 & 14 & 2 & - & 100 & 64 \\
\hline Tillage and hay, . NoN- & FOREST' & YPES. & . & . & 4,250 & - & 17 \\
\hline Open pasture, $\quad$. & . & . & . & . & 1,830 & - & $\cdot 7$ \\
\hline Brush pasture, . & . & . & . & . & 1,700 & - & 7 \\
\hline Alder and brush swamp, & . 8. & . & . & . & 120 & - & 1 \\
\hline Business, residential, etc., & . & . & . & . & 160 & - & \\
\hline Water, . . & . & . & . & . & 990 & - & 4 \\
\hline Total area of town, . & . & . & . & . & 24,940 & $\overline{-}$ & 100 \\
\hline
\end{tabular}

SutTon.

The inost common wood types are chestnut, gray birch and maple. White pine is rare, except along the southern border of the town and around the drier shores of the ponds. In such locations good stands occur. Most of the timber is in the small merchantable class. The ridges are stocked to almost 100 
per cent. with chestnut and chestnut and oak, and the lake regions in particular bear heavy stands. Many of the ridge tops have been cut over within the last three or four years, and as a result bear dense growths of chestnut and oak sprouts. In the southeastern part of the town some of the timber owned by the Whitin Machine Works runs to a large diameter size, but timber larger than size 2 is very rare. The stands are usually dense, and the timber of excellent form and shape. In that region known as Purgatory and to the south, including the Whitin Game Preserve, are stands of chestnut and pine of Class 2, and some even larger. The stands will run to practically 100 per cent. stocking. In the south, central and eastern parts of the town are large areas as yet not cut by roads. Such areas are almost entirely covered with a timber growth, generally chestnut of sizes 3 to 2. Oak seldom occurs above a size 2, generally sizes 3 and 4 . The same is true of the mixed hardwoods.

Mr. John Dudley has recently operated on a tract containing about $800 \mathrm{M}$ board feet. Chestnut with some white pine was the principal species cut. Mr. Dudley's mill is operated electrically by power obtained from Saundersville.

Land Types.

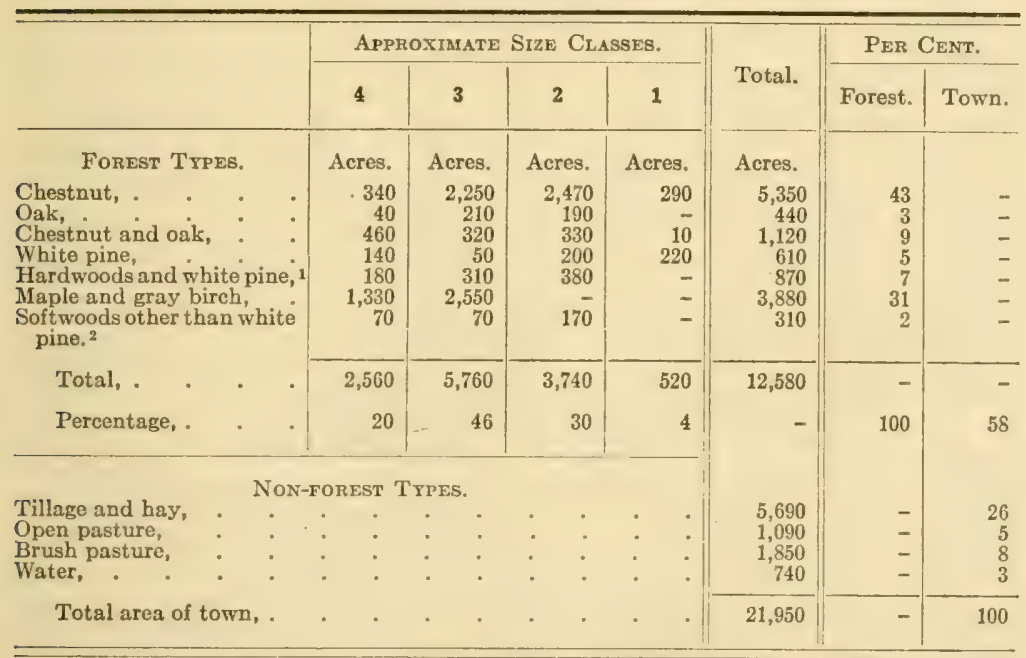

1 Hardwoods are gray birch, red maple and poplar.

2 Mostly white cedar. 


\section{Templeton.}

Templeton seems to be a natural white pine region. Although the entire town has been pretty much cut over, there are still some good white pine stands remaining, scattered through different parts of the town. Two of the best of these are in the extreme northern and in the extreme southern portions of the town. There is practically no virgin growth standing. The hardwoods are mostly coppice, and the greater portion of them are unmerchantable. The town contains considerable spruce and American larch. The best spruce is in a mixture with white pine on the land of the State School for Feeble-minded in the northern part of the town. Some of this spruce calipered from 18 to 22 inches diameter, breast high. White birch occupies a good proportion of the forested area. The principal trees found here are white pine, chestnut, oak, white birch, spruce, hemlock, maple, American larch, beech, white ash, and, as usual, an abundance of gray birch.

Templeton has two sawmills; one situated at Templeton Center and owned by Bourn \& Hadley cuts about 1,000,000 board feet of native stock per year. At Otter River there is a mill owned by Louis LaPorte, with a capacity of 8 M board feet per day when it runs. This mill saws native stock only.

Among the wood-using industries are the following:-

\begin{tabular}{|c|c|c|c|c|c|c|c|c|c|c|c|c|}
\hline \multicolumn{8}{|c|}{ Name. } & \multicolumn{3}{|c|}{ Product. } & \multicolumn{2}{|r|}{$\begin{array}{l}\text { Approximate } \\
\text { Output } \\
\text { (Board Feet.) }\end{array}$} \\
\hline Now England Box & ompar & & - & & $\cdot$ & ${ }^{\circ}$ & . & Boxes, . & . & . & . & $7,000,000$ \\
\hline Smith, Day \& Co. & . & . & . & . & . & • & . & Chairs, . & - & . & - & 800,000 \\
\hline Bishop \& Dickins & . & . & - & • & - & $\cdot$ & . & Chairs, . & - & - & - & 125,000 \\
\hline Waite Chair Com & & . & - & • & • & $\bullet$ & . & Chairs, . & - & . & - & 600,000 \\
\hline E. L. Thompson & & - & ${ }^{\circ}$ & • & - & $\cdot$ & . & Chairs,. & - & . & - & 600,000 \\
\hline Temple, Stewart & apany & & - & • & - & • & . & Chairs, . & - & . & . & 175,000 \\
\hline Children's Vehicle & rpora & tion, & - & - & . & 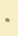 & . & Go-carts, & - & - & - & 700,000 \\
\hline Bourn \& Hadley, & . & . & . & . & . & - & . & Office fur & ture, & - & . & - \\
\hline
\end{tabular}

These concerns use pine, maple, oak, spruce, beech, tulip, poplar and white and yellow birch. A considerable amount of this lumber is obtained from outside the State. 
Land Types.

\begin{tabular}{|c|c|c|c|c|c|c|c|c|}
\hline & & \multicolumn{4}{|c|}{ Approximate Size Crasses. } & \multirow{2}{*}{ Total. } & \multicolumn{2}{|c|}{ Per Cent. } \\
\hline & & 4 & 3 & 2 & 1 & & Forest. & Town. \\
\hline \multicolumn{2}{|c|}{ Forest Types, } & Acres. & Acres. & Acres. & Acres. & Acres. & & \\
\hline Chestnut, . & - & 40 & 10 & 10 & - & 60 & 1 & - \\
\hline Oak, . . & - & 150 & 230 & 260 & 110 & 750 & 6 & - \\
\hline Chestnut and oak, & . & 140 & 390 & 170 & 50 & 750 & 6 & - \\
\hline White pine, & . & 370 & 950 & 1,350 & 660 & 3,330 & 25 & - \\
\hline \multicolumn{2}{|c|}{ Hardwoods and white pine, 1} & 2,140 & 1,000 & 150 & - & 3,290 & 25 & - \\
\hline Maple and birch, & - & 2,470 & 1,560 & 400 & 80 & 4,510 & 34 & - \\
\hline \multicolumn{2}{|c|}{$\begin{array}{l}\text { Softwoods other than white } \\
\text { pine. } 2\end{array}$} & 100 & 230 & 80 & 20 & 430 & 3 & - \\
\hline Total, . . & - & 5,410 & 4,370 & 2,420 & 920 & 13,120 & - & - \\
\hline Percentage, . & - & 41 & 33 & 19 & 7 & - & 100 & 63 \\
\hline \multicolumn{6}{|c|}{ NON-FOREST TYPES. } & 4,520 & - & 22 \\
\hline Open pasture, & - & - & - & - & . & 1,830 & - & 9 \\
\hline Brush pasture, & . & - & - & . & $\cdot$ & 890 & - & 4 \\
\hline \multicolumn{2}{|c|}{ Business, residential, etc., } & - & . & - & - & 70 & - & - \\
\hline Water, - & . & . & - & . & $\cdot$ & 370 & - & 2 \\
\hline \multicolumn{2}{|c|}{ Total area of town, . } & . & . & . & $\cdot$ & 20,800 & - & 100 \\
\hline
\end{tabular}

1 Hardwoods are largely maple and gray birch, with small amounts of white birch and oak.

2 Large sizes, mostly hemlock and spruce; smaller, tamarack and pitch pine.

\section{UPTON.}

The timber land in Upton has been largely cut over within twenty years, and most of the land is growing Class 3 sprouts. Gray birch is more common in Upton than in most of the surrounding towns, and the percentage of white oak is greater; probably over half the oak in Upton is white oak. Chestnut and white pine and hardwoods are the most important types. There are several lots of merchantable pine still left in Upton, but mostly in patches of a few acres each.

At the time this survey was made the only mill working in Upton was the portable mill of D. W. Gaskill of Blackstone. He had about 300 MI board feet to cut, mostly chestnut, oak and pitch pine. Mr. B. C. Wood of Upton does considerable cutting in Upton and near-by towns. The Upton Manufacturing Company is a box company primarily, but they have their 
own sawmill operated by water power. They use only local pine. The IV. G. Fiske Lumber Company have a stationary mill, but do not do much cutting themselves. This past year they cut and sawed about 100 M board feet of lumber of which 75 per cent. was pine, the remainder being chestnut and oak.

Land Types.

\begin{tabular}{|c|c|c|c|c|c|c|c|c|}
\hline & & \multicolumn{4}{|c|}{ Approximate Syze Claeses. } & \multirow{2}{*}{ Total. } & \multicolumn{2}{|c|}{ Per Cent. } \\
\hline & & 4 & 3 & 2 & 1 & & Forest. & Town. \\
\hline \multicolumn{2}{|c|}{ Forest TyPes. } & Acres. & Acres. & Acres. & Acres. & Acres. & & \\
\hline Chestnut, . & - & 510 & 380 & 350 & 40 & 1,280 & 14 & - \\
\hline $\mathrm{Oak}^{1}$ & . & 340 & 410 & 130 & 30 & 910 & 10 & - \\
\hline Chestnut and oa? & $s$, . & 440 & 230 & 30 & 30 & 730 & 8 & - \\
\hline White pine, & - & 120 & 390 & 10 & 180 & 700 & 8 & - \\
\hline \multicolumn{2}{|c|}{ Hardwoods and white pine, 2} & 980 & 760 & 70 & 30 & 1,840 & 20 & - \\
\hline \multirow{2}{*}{\multicolumn{2}{|c|}{$\begin{array}{l}\text { Maple and gray birch, } \\
\text { Softwoods other than white } \\
\text { pine. }{ }^{3}\end{array}$}} & 2,310 & 1,050 & 60 & - & 3,420 & 38 & - \\
\hline & & 100 & 50 & - & - & 150 & 2 & - \\
\hline Total, & - & 4,800 & 3,270 & 650 & 310 & 9,030 & - & - \\
\hline Percentage, . & . & 53 & 36 & 7 & 4 & - & 100 & 65 \\
\hline \multicolumn{6}{|c|}{ NoN-Forest TrPes. } & 3,030 & - & 22 \\
\hline Open pasture, & - & . & - & . & . & 1,050 & - & 7 \\
\hline Brush pasture, & - & - & - & - & - & 600 & - & 4 \\
\hline Brush swamp, & - & - & - & . & . & 90 & \multirow{3}{*}{-} & \multirow{3}{*}{2} \\
\hline \multicolumn{2}{|c|}{ Business, residential, etc., } & . & . & - & - & 20 & & \\
\hline Water, . . & $\cdot \quad \cdot$ & - & - & . & - & 140 & & \\
\hline \multicolumn{2}{|c|}{ Total area of town,. } & . & : & . & . & 13,960 & - & 100 \\
\hline
\end{tabular}

1 About one-third of the oak type is made up of white oak.

2 Hardwoods are maple and gray birch.

3 Pitch pine.

\section{UXBRIDGE.}

The woodlands constitute about 70 per cent. of the area of the entire town, the principal species being pitch and white pine, oak and chestnut. The general condition of the timber is fair. There are numerous open spaces - as a result of lumbering operations, forest fires and the abandoning of farmswhich could profitably be reforested. The best timber lies in the south central portion, and ranges from Class 3 to Class 1 , with a stocking in some parts of 100 per cent. 
The sawmill of Newell \& King cuts during the late fall and winter months from 300 to $700 \mathrm{M}$ board feet of pine, chestnut and oak, probably 75 per cent. of the whole cut being pine.

The Uxbridge branch of Wm. M. Harris, Providence, R. I., deals in southern and western pine, shingles and cordwood. This concern buys only cordwood locally, and this from woodlot owners who deliver the same.

IV. B. Tucker cuts pine and chestnut when they can be bought.

Land Types.

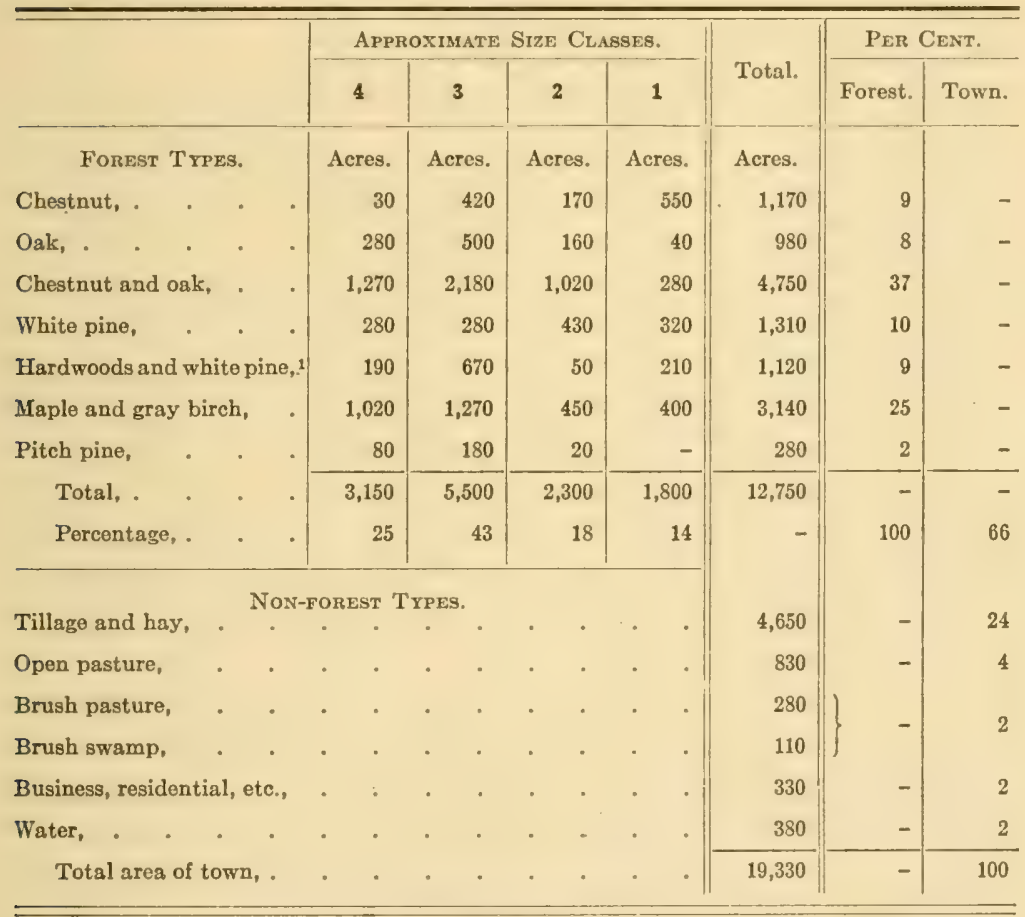

1 Larger sizes are mostly red maple; smaller, gray birch.

\section{WARREN.}

The woodland is chiefly a second growth of chestnut and oak. In the southern section there is a large area of young mixed hardwoods. A few stands of good merchantable chestnut and oak are left, but they are small and scattered. Pine forms a still smaller percentage of the forest growth in this town than it does in West Brookfield. The best stand of white pine is found 
around Comins Pond. Elm swamps are to be found, but these are so rare that they have been classed as mixed hardwoods.

There are no operators in Warren. Mr. H. N. Shepard deals more or less in lumber, but he contracts for portable mills from outside to do his work. The lumber sawed is chiefly chestnut, oak and pine, with some ash, birch and maple.

Land Types.

\begin{tabular}{|c|c|c|c|c|c|c|c|c|c|}
\hline & & & \multicolumn{4}{|c|}{ Approximate Size Classes. } & \multirow{2}{*}{ Total. } & \multicolumn{2}{|c|}{ Pen Cent. } \\
\hline & & & 4 & 3 & 2 & 1 & & Forest. & Town. \\
\hline \multicolumn{3}{|c|}{ Forest Types. } & Acres. & Acres. & Acres. & \multirow{2}{*}{$\begin{array}{r}\text { Acres. } \\
440\end{array}$} & \multirow{2}{*}{$\begin{array}{l}\text { Acres. } \\
1,280\end{array}$} & \multirow[b]{2}{*}{18} & \multirow[b]{2}{*}{ - } \\
\hline Chestnut, . & & . 1 & 60 & 340 & 440 & & & & \\
\hline Oak, . . . & . &. & 50 & 140 & 80 & 10 & 280 & 4 & - \\
\hline \multicolumn{2}{|c|}{ Chestnut and oak, . } & . & 430 & 560 & 120 & 170 & 1,280 & 18 & - \\
\hline White pine, & - & . & 120 & - & 10 & 70 & 200 & 3 & - \\
\hline \multicolumn{3}{|c|}{ Hardwoods and white pine, 1} & - & 190 & 50 & - & 240 & 4 & - \\
\hline \multirow{2}{*}{\multicolumn{3}{|c|}{$\begin{array}{l}\text { Maple and gray birch, } \\
\text { Softwoods other than white } \\
\text { i pine. }\end{array}$}} & 1,720 & 1,250 & 610 & 10 & 3,590 & 52 & - \\
\hline & & & 50 & 50 & - & - & 100 & 1 & - \\
\hline Total, . & - & $\cdot$ & 2,430 & 2,530 & 1,310 & 700 & 6,970 & - & - \\
\hline Percentage, . & - & $\cdot$ & 35 & 36 & 19 & 10 & - & 100 & 38 \\
\hline \multicolumn{7}{|c|}{ Non-Fonest TxPES. } & 4,030 & - & 22 \\
\hline Open pasture, & - & - & - & . & . & - & 6,660 & -1 & 37 \\
\hline Brush pasture, & - & $\cdot$ & . & - & - & - & 420 & - & 2 \\
\hline Brush swamp, & - & - & - & . & $\cdot$ & - & 20 & \multirow{2}{*}{-} & \multirow{2}{*}{1} \\
\hline Water, . . & . & - & . & . & - & - & 130 & & \\
\hline \multicolumn{3}{|c|}{ Total area of town, . } & - & - & . & . & 18,230 & -1 & 100 \\
\hline
\end{tabular}

1 Hardwoods are largely gray birch and maple.

2 Pitch pine.

\section{WEBSTER.}

The wooded section of this town is in a condition of healthy, rapid growth. Burned areas in the northeastern and southcastern corners are restocking with chestnut and oak sprouts, maple and birch. The best timber lies along the shores and to the east of Lake Chaubunagungamaug. There are many small areas of white pine, and reproduction is generally good. The proportion of woodland to the total area of the town is about 60 per cent. 
Louis E. Pattison saws mostly pine, chestnut and oak from the towns of Webster, Douglas, Sturbridge, Charlton, Oxford and Thompson (Conn.). He saws about $350 \mathrm{M}$ board feet per year of pine, chestnut and mixed hardwoods.

Land Types.

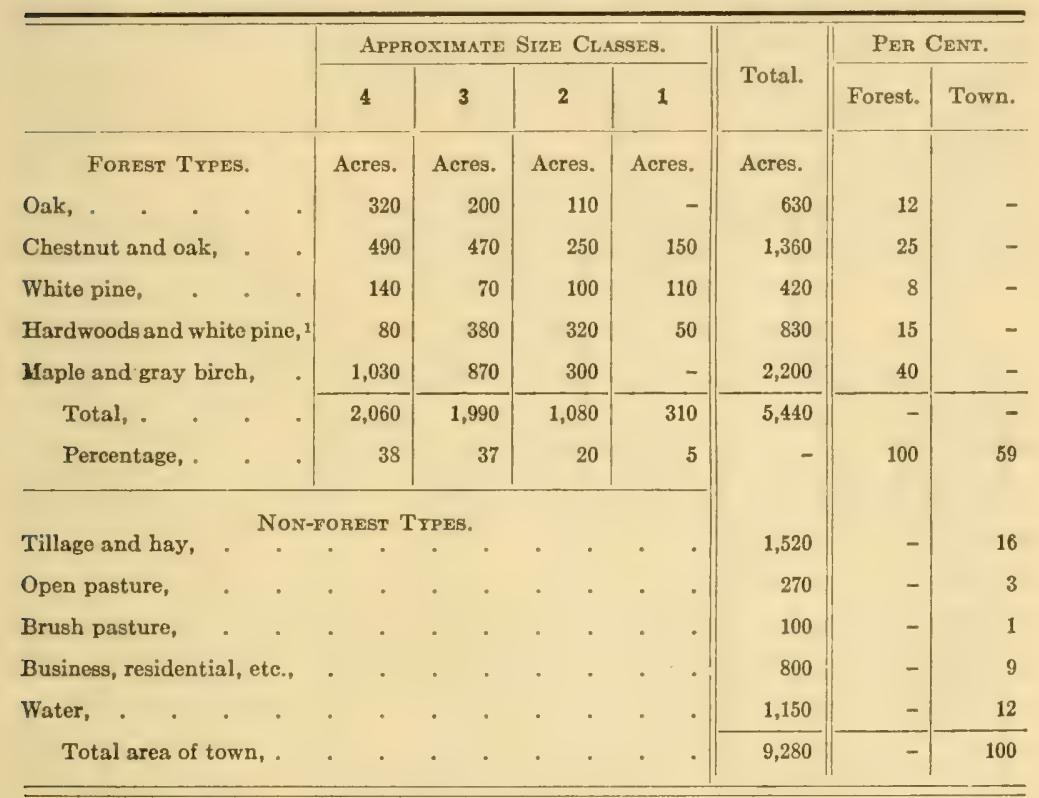

1 Hardwoods are largely gray birch and red maple.

\section{West Boylston.}

While there is very little timber of merchantable size, the majority of that standing is in good, healthy condition. About 55 per cent. of the town is either pasture or tilled land. The remainder, with the exception of the water area, is covered with a wooded growth, chestnut being the predominating species. Chestnut also occurs mixed with oak and white pine.

The best timber is on the land owned by the Metropolitan Water Works; and while much of this is small and worth little now, it is only a matter of time until it will form a valuable forest. Size classes range from reproduction to 2 , but the majority will fall under 10 inches diameter, breast high.

White pine growing naturally occurs well scattered. Around the reservoir extensive planting of this species has been carried 
on, the planted trees now ranging from one to ten years in age. Red and Scotch pine have also been planted, but to a much less degree. These trees are making exceptionally rapid growth, some of the older ones averaging 2 feet in height annually. The best specimens are found in the northeastern corner of the town.

There are no sawmills or woodworking industries now located in this town, and there have been none since the reservoir was built. No portable mills were working when this survey was made.

Land Types.

\begin{tabular}{|c|c|c|c|c|c|c|c|c|c|}
\hline & & & \multicolumn{4}{|c|}{ Approxmate Size Classses. } & \multirow{2}{*}{ Total. } & \multicolumn{2}{|c|}{ Per Cent. } \\
\hline & & & 4 & 3 & 2 & 1 & & Forest. & Town. \\
\hline \multicolumn{3}{|c|}{ Forest Trpes. } & Acres. & Acres. & Acres. & Acres. & Acres. & & \\
\hline Chestnut, . & & $\cdot$ & 10 & 150 & 370 & 70 & 600 & 19 & - \\
\hline Oak, . & & $\cdot$ & 100 & 130 & 120 & - & 350 & 11 & - \\
\hline \multicolumn{2}{|l|}{ Chestnut and oak, } & . & 220 & 360 & 390 & - & 970 & 30 & - \\
\hline White pine, & &. & 180 & 170 & 300 & 40 & 690 & 21 & - \\
\hline \multicolumn{3}{|c|}{ Hardwoods and white pine, 1} & 10 & 70 & 30 & - & 110 & 3 & - \\
\hline \multicolumn{2}{|c|}{ Mixed hardwoods, ${ }^{2}$. } & . & 210 & 170 & 60 & - & 440 & 14 & - \\
\hline \multicolumn{3}{|c|}{$\begin{array}{l}\text { Softwoods other than white } \\
\text { pine. }{ }^{3}\end{array}$} & 30 & 40 & - & - & 70 & 2 & - \\
\hline Total, .. . & & $\cdot$ & 760 & 1,090 & 1,270 & 110 & 3,230 & - & - \\
\hline Percentage, . & & $\cdot$ & 24 & 34 & 39 & 3 & - & 100 & 37 \\
\hline \multicolumn{7}{|c|}{ NON-FOREST TYPES. } & 4,110 & - & 47 \\
\hline Open pasture, & . & - & . & . & . & . & 640 & - & 7 \\
\hline Brush pasture, & - & . & - & . & . & . & 140 & 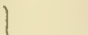 & ? \\
\hline Brush swamp, & - & - & - & . & . & . & 40 & & \\
\hline Water, . & . & . & . & . & . & . & 660 & - & 7 \\
\hline \multicolumn{3}{|c|}{ Total area of town, } & . & . & . & . & 8,820 & - & 100 \\
\hline
\end{tabular}

1 Hardwoods are birch, chestnut, oak and red maple.

8 Pitch pine.

2 Swamp maple, red maple and gray birch.

\section{West Brookfield.}

Nearly all the woodland is second growth hardwoods, chiefly chestnut and oak. Here and there are small patches of good merchantable material. Broadly speaking, probably less than one-third of the town is covered with species which will develop into large timber. The chief species are chestnut and oak, 
while the old pastures are fast growing up to gray birch. Soft maple occurs in the swamps, but the size of this is small, and it is of little practical importance. White pine occurs scatteringly in small percentages in nearly all types, but the only place where pure stands are likely to develop naturally is in the extreme eastern part. Located in this section is a fine but small tract of merchantable hemlock.

There are two stationary sawmills. One is owned by D. Tyler and is located east of Ragged Hill on Mill Brook. This mill is run by water power. The other is a gasoline sawmill owned by Henry Foster on Long Hill in the extreme southern part of the town. Both of these operators do only small odd jobs as the needs of the neighbors require. The logs for these purposes are supplied by the farmers.

The chief out-of-town operators are George Wasson and A. N. Cony of Ware, and Messrs. Cummings and Fullam of North Brookfield. The lumber sawed is mostly chestnut, oak and pine, with some ash, birch and maple.

Land Types.

\begin{tabular}{|c|c|c|c|c|c|c|c|c|c|}
\hline & & & \multicolumn{4}{|c|}{ Approximate Size Classes. } & \multirow{2}{*}{ Total. } & \multicolumn{2}{|c|}{ Per Cent. } \\
\hline & & & 4 & 3 & 2 & 1 & & Forest. & Town. \\
\hline \multicolumn{3}{|c|}{ Forest TYPES. } & Acres. & Acres. & Acres. & Acres. & Acres. & & \\
\hline Chestnut, . & - & $\cdot$ & 220 & 490 & 280 & 320 & 1,310 & 20 & - \\
\hline Oak, . . & - & $\cdot$ & 30 & - & 90 & 40 & 160 & 2 & - \\
\hline Chestnut and oal & ; & . & 540 & 230 & 330 & 30 & 1,130 & 18. & - \\
\hline White pine, & - & $\cdot$ & 50 & 100 & 40 & 20 & 210 & 3 & - \\
\hline \multicolumn{3}{|c|}{ Hardwoods and white pine, 1} & 180 & 180 & 70 & -1 & 430 & 7 & - \\
\hline \multirow{2}{*}{\multicolumn{3}{|c|}{$\begin{array}{l}\text { Maple and gray birch, } \\
\text { Softwoods other than white } \\
\text { pine. }{ }^{2}\end{array}$}} & 1,110 & 1,550 & 550 & 20 & 3,230 & 49 & - \\
\hline & & & 20 & 20 & - & 20 & 60 & 1 & - \\
\hline Total, . & & & 2,150 & 2,570 & 1,360 & 450 & 6,530 & - & - \\
\hline Percentage, . & - & $\cdot 1$ & 33 & 39 & 21 & 7 & - & 100 & 48 \\
\hline \multicolumn{7}{|c|}{ NON-FOREST TYPES. } & 2,910 & - & 22 \\
\hline Open pasture, & - & - & - & - & - & - & 3,070 & - & 23 \\
\hline Brush pasture, & - & - & - & - & - & - & 600 & - & 4 \\
\hline Water, . . & - & - & - & - & - & - & 390 & - & 3 \\
\hline \multicolumn{3}{|c|}{ Total area of town, . } & - & . & . & - & 13,500 & - & 100 \\
\hline
\end{tabular}

1 Hardwoods are gray birch and red maple.

2 Mostly pitch pine with some hemlock. 


\section{WESTBOROUGH.}

The proportion of woodland is about 45 per cent., all in good condition, but mostly of small growth. There is a noticeable dearth of timber of all kinds on the land best adapted to growing it. A few wooded hills remain, covered with chestnut, oak and pine, but by far the greater part of the timber consists of soft maple, birch and cedar, running from Class 2 down to reproduction, and this lies in or near the swamps. At the present time little timber is being cut in Westborough, there being no mills and but one woodworking factory. Cordwood is handled only by dealers in coal and wood.

Frank Bartlett, owner of a box factory, cuts no timber. He uses spruce, pine shingles and some chestnut and oak. He uses about $3,000,000$ board feet per year, most of which is obtained from outside of Massachusetts.

Land Types.

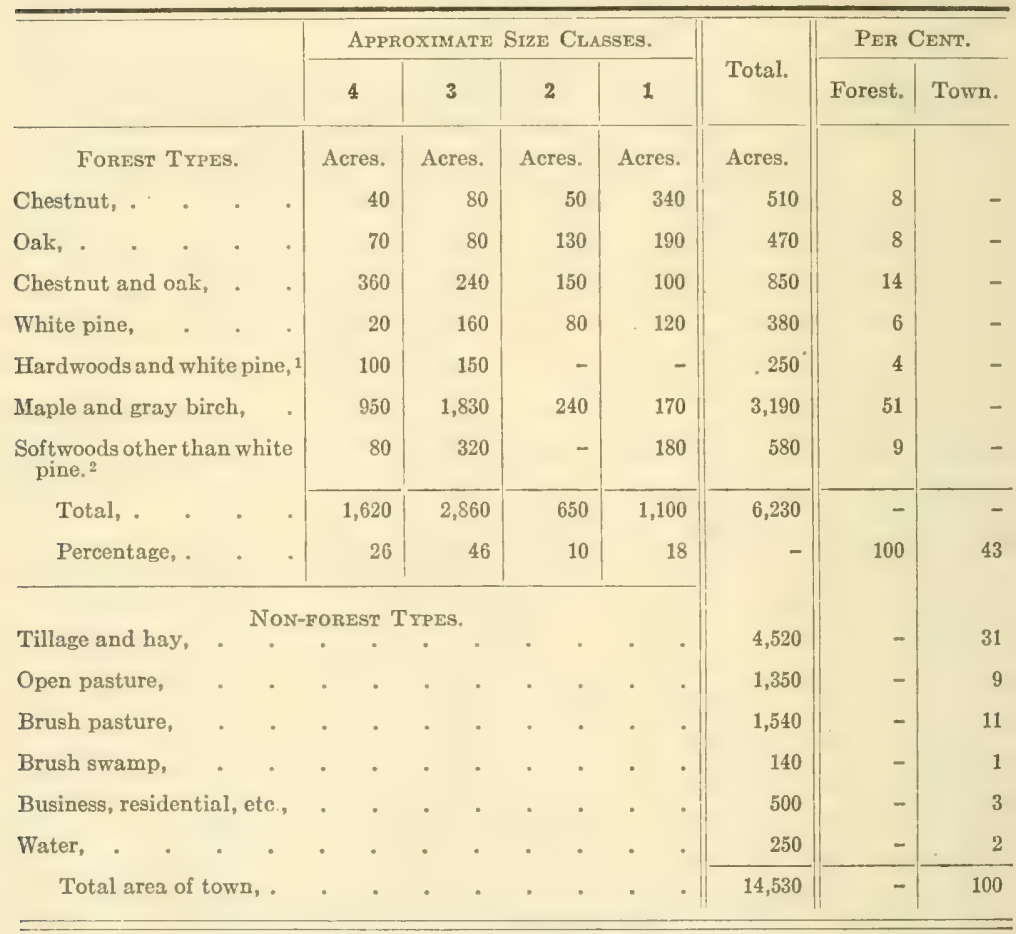

I Hardwoods are largely gray birch, red maple and poplar.

2 Pitch pine in the large sizes; white cedar in the smaller sizes. 


\section{WESTMinster.}

The woodlands of the town are largely in a state of neglect. The major growth is chestnut and hardwoods, with scattered stands of pine. There is considerable growth of pine in the north and east parts of the town. There is much swamp covered with maple, birch, spruce and alder. Many areas are found where cutting has been done, removing everything merchantable, leaving the land butchered, with slash and débris scattered about, forming veritable tinder piles. These areas occur throughout the township. This land is now growing up to gray birch, sprout chestnut or brush, and is well-nigh in a useless condition. Thinnings are needed everywhere and reforestation in many places. This last operation has been done to considerable extent. Careful forest management is needed in this town as in other towns examined. Fires have run through the cut-over lands and left them in a very poor condition. Practically all merchantable stuff has been cut.

In Westminster village is a box mill, belonging to Mr. Goodridge, which uses per year 1,500,000 feet of pine, spruce and hemlock. Most of the stock is obtained from outside the State because Westminster's supply and the stock near by is depleted. Last year 200 MI board feet were cut here, the remainder coming from New Hampshire. E. H. Merriam runs a sawmill near Westminster depot in connection with his grain business. Sawing is done irregularly, and is largely custom work. This mill saws perhaps $500 \mathrm{M}$ board feet to $1,000 \mathrm{M}$ board feet per year. Pierce's chair mill at Whitmanville in the northerly part of the township uses 1,500,000 feet of chestnut per year. This comes from Pennsylvania, New Hampshire and New York. Two million feet of turned stock per year are used. 
Land Types.

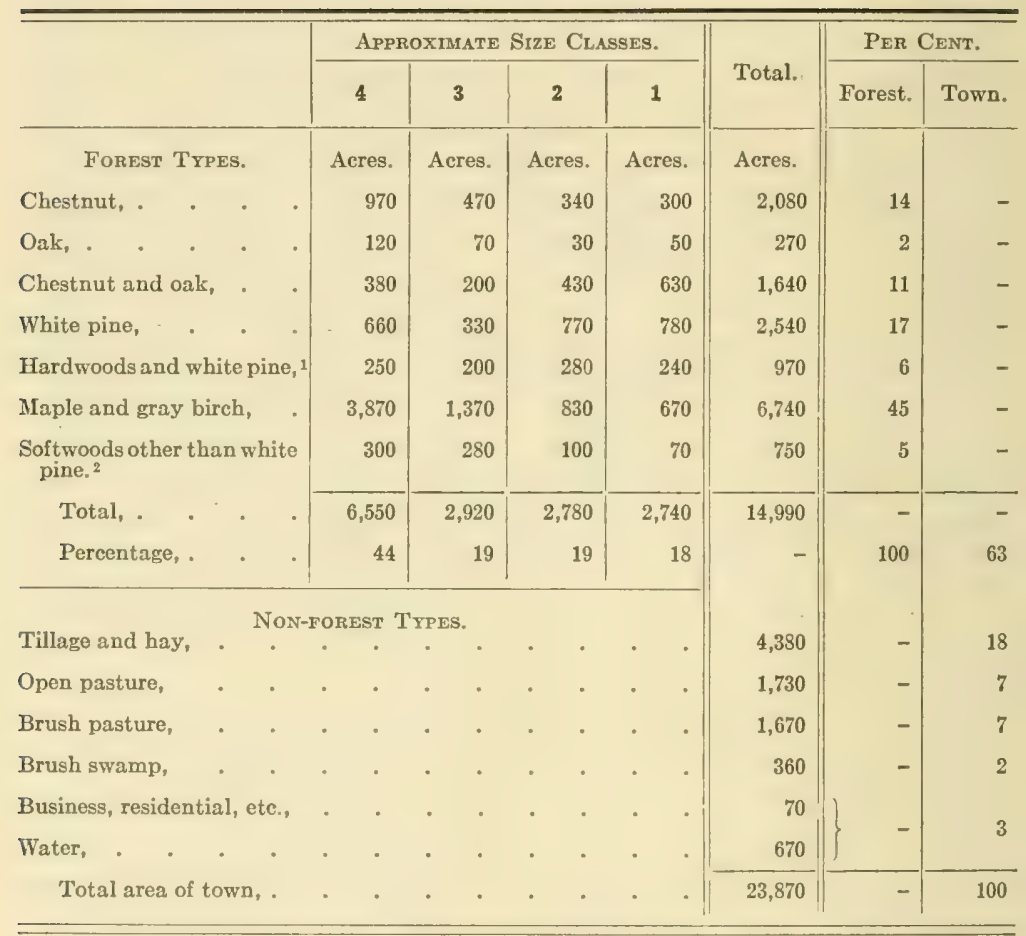

1 Hardwoods are largely gray birch and maple.

2 Pitch pine and hemlock.

\section{WiNCHENDON.}

Regarding the town as a whole, white pine is the predominating species. As a rule, it is thrifty and growing rapidly, but considerable damage caused by the weevil was noticed in some of the younger stands. It might be mentioned that, in general, although the pine stands are healthy and growing, they are understocked.

The gray birch and maple type, although at the present time covering a much larger area than the white pine, seems likely to be eventually suppressed by the latter.

Spruce, hemlock and larch were found scattered throughout the town in moist places. Considerable hemlock is found in the western part of the town, generally in mixture with pine and of 
about the same age. In the swamps and bogs spruce, hemlock and larch are found, either pure, together, or in different combinations with lowland hardwoods, such as red maple and the various birches.

The sizes of the different types vary from reproduction to 1.

Mr. C. A. Brooks runs a sawmill in connection with his handle factory. He cuts per year $45 \mathrm{M}$ board feet of spruce, $25 \mathrm{M}$ board feet of hemlock, and $180 \mathrm{M}$ board feet of pine. Nearly all of this lumber is bought in New Hampshire.

M. E. Converse \& Sons own a toy factory, and use the following amount of board feet of lumber per annum: white pine, 1,000 M; chestnut, 250 to $300 \mathrm{M}$; basswood, $75 \mathrm{M}$; red gum, $50 \mathrm{M}$; miscellaneous, $100 \mathrm{M}$.

C. A. Brooks' handle factory uses about 400 cords of beech, birch and maple per year. Practically all of this comes from New Hampshire.

Wm. Brown \& Son manufacture pails and ice-cream freezers. They use about 3,500 cords of pine annually.

Mason \& Parker, toy manufacturers, use per annum: basswood, 200 M board feet; chestnut, 250 M board feet; poplar, 150 M board feet; pine, 100 M board feet; beech, birch and maple, $25 \mathrm{M}$ board feet.

Carter \& Campbell, furniture manufacturers, use per annum: spruce, 40 to $45 \mathrm{M}$ board feet; maple, $30 \mathrm{M}$ board feet; ash and miscellaneous hardwoods, $15 \mathrm{M}$ board feet.

M. A. Parks, manufacturer of spools and bobbins, uses basswood, 500 M board feet; birch, 500 M board feet; pine, 1-inch boards, and pine, $2 \frac{1}{8}$ inch boards, 100 M board feet; Pennsylvania beech, $50 \mathrm{M}$ board feet.

E. Murdock \& Co., manufacturers of pails and tubs, use 7,500 cords of pine logs; 1,500 cords of spruce, hemlock and hardwoods; 750 M board feet of $2 \frac{1}{8}$ inch pine plank; and 500 M board feet of 1 -inch hardwood boards. 
Land Types.

\begin{tabular}{|c|c|c|c|c|c|c|c|c|}
\hline & & \multicolumn{4}{|c|}{ Approximate Size Classes. } & \multirow{2}{*}{ Total. } & \multicolumn{2}{|c|}{ Per Cent. } \\
\hline & & 4 & 3 & 2 & 1 & & Forest. & Town. \\
\hline \multicolumn{2}{|c|}{ FOREST TYPES. } & Acres. & Acres. & Acres. & Acres. & Acres. & & \\
\hline \multicolumn{2}{|c|}{ Chestnut and oak, } & 270 & 320 & 470 & 160 & 1,220 & 6 & - \\
\hline White pine, . & . & 1,220 & 1,070 & 1,970 & 680 & 4,940 & 25 & - \\
\hline Mixed hardwoods, & 1. & 10 & 140 & 100 & 30 & 280 & 1 & - \\
\hline \multirow{2}{*}{\multicolumn{2}{|c|}{ Maple and gray birch, }} & $M .1,460$ & 1,510 & 700 & 70 & 3,740 & 19 & - \\
\hline & & B. 5,570 & 1,640 & 170 & - & 7,380 & 38 & - \\
\hline \multicolumn{2}{|c|}{$\begin{array}{l}\text { Softwoods other than white } \\
\text { pine. }{ }^{2}\end{array}$} & 320 & 680 & 910 & 330 & 2,240 & 11 & - \\
\hline Total, . . & - & 8,850 & 5,360 & 4,320 & 1,270 & 19,800 & - & - \\
\hline Percentage, . & - & 45 & 27 & 22 & 6 & - & 100 & 68 \\
\hline \multicolumn{6}{|c|}{ NON-FOREST TrPes. } & 4,350 & - & 15 \\
\hline Open pasture, & . & . & . & . & . & 1,170 & - & 4 \\
\hline Brush pasture, & . & . & . & . & . & 1,760 & - & 6 \\
\hline \multicolumn{2}{|c|}{ Business, residential, etc., } & . & . & . & . & 1,240 & - & 4 \\
\hline Water, . . & - & . & - & - & - & 800 & - & 3 \\
\hline \multicolumn{2}{|c|}{ Total area of town, . } & - & . & . & . & 29,120 & - & 100 \\
\hline
\end{tabular}

1 Hardwoods are beech, hard maple and white birch.

2 Spruce, hemlock, pitch pine and a little red pine.

\section{WORCESTER.}

Worcester is more interesting as a consumer of lumber than as a producer. Its percentage of woodland, 21, is far less than any other township in the county. What there is is valued far in excess of its timber value for residential and rsthetic purposes. For this reason the percentage of woodland in larger sizes is unusually large. Chestnut predominates, either pure or mixed with oak, while white pine is deficient and under the average percentage. The woodland is generally in good condition, except for the chestnut blight, which has done considerable damage in many sections. The woodland around Lake Quinsigamond shows the result of many ground fires.

A large manufacturing city like Worcester is naturally a large consumer of lumber, both for construction purposes and in its industries. Most of this lumber, however, comes from outside the State, as is the general run with our lumber supply. The 
principal consumers of native lumber are the box manufacturers, of which there are two large concerns in Worcester. This city, with its numerous car lines and electric companies, offers a good market for ties and poles. Some native white oak is used by the car builders, and it is probable that some native white pine is used by the makers of sash, blinds and interior finish. Worcester offers a good cordwood market, but the supply in the vicinity is ample, so that prices are rather low. The following industries make up the principal timber consumers of Worcester: -

\section{Box Manufacturers.}

Baker Box Company.

Williams \& Bridges.

$$
\text { H. I. Gould. }
$$

Caskets.

F. E. Sessions Company.

Sash and Interior Finish.

Griffin Flooring Company.

Adams \& Powers.

Hatch \& Barnes.

E. F. Hunt Company.
W. E. Putnam.

M. K. Smith Company.

Frank O. Stevens.

Henry Braman.

Eaves and Troughs.

A. C. Lead Company.

Edw. W. Witter \& Co.

General Lumber Dealers.

F. O. Arnold.

Baker Lumber Company.

J. F. Bicknell Lumber Company.

J. W. Bishop Company.

Henry H. Dyke.

John H. Grant.

Edward A. Hackwell.
Frederick S. Hunt.

New England Lumber Company.

William H. Sawyer Company.

Stone \& Berg.

Stone \& Foster.

P. W. Wood Lumber Company.

Woodland Operators.

George L. Jacques.

Frank O. Arnold.

M. Bagdasarian.

George L. Jacques.

Frank O. Arnold.

M. Bagdasarian.

Chas. T. Luce.

H. I. Gould.

Tie and Pole Operators.

Chas. T. Luce.

H. I. Gould. 
Lasts.

S. Porter \& Co.

Agricultural Implements.

Richardson Manufacturing Com- | Worcester Lawn Mower Company. pany.

Car Builders.

Osgood-Bradley Company.

Piano Players.

Simplex Player Company.

Weber Piano Company.

Refrigerators.

F. A. Atherton Company.

M. M. Whitman.

Cordwood Dealers.

Ararat Wood Company.

David Bergerau.

Walker Ice Company.

E. Perreault.

F. O. Arnold.

Claflin Coal Company.

F. P. Defaleo.

New England Fuel Company.

Worcester Fuel Company.

F. E. Powers Company.

Land Types.

\begin{tabular}{|c|c|c|c|c|c|c|c|c|}
\hline & & \multicolumn{4}{|c|}{ Approximate Size Classes. } & \multirow{2}{*}{ Total. } & \multicolumn{2}{|c|}{ Per Cent. } \\
\hline & & 4 & 3 & 2 & 1 & & Forest. & Town. \\
\hline \multicolumn{2}{|c|}{ FOREST TYPES. } & Acres. & Acres. & Acres. & Acres. & Acres. & & \\
\hline Chestnut, . & - & 90 & 100 & 230 & 310 & 730 & 14 & - \\
\hline Oak, . & . & 20 & 360 & 30 & 60 & 470 & 9 & - \\
\hline Chestnut and oak, & . & 410 & 420 & 960 & 210 & 2,000 & 39 & - \\
\hline White pine, & . & 20 & - & 70 & 150 & 240 & 5 & - \\
\hline \multicolumn{2}{|c|}{ Hardwoods and white pine, } & - & 140 & 50 & 310 & 500 & 10 & - \\
\hline \multicolumn{2}{|c|}{ Maple and gray birch, } & 310 & 610 & 180 & 20 & 1,120 & 22 & - \\
\hline Pitch pine, & - & 10 & - & - & 30 & 40 & 1 & - \\
\hline Total, . & . & 860 & 1,630 & 1,520 & 1,090 & 5,100 & - & - \\
\hline Percentage, . & - & 17 & 32 & 30 & 21 & - & 100 & 21 \\
\hline \multicolumn{6}{|c|}{ Tillage and hay, NoN-Forest TrPes. } & 8,040 & - & 32 \\
\hline Open pasture, & - & - & . & - & $\cdot$ & 2,800 & - & 11 \\
\hline Brush pasture, & $\cdots$ & . & - & - & $\cdot$ & 680 & - & 3 \\
\hline \multicolumn{2}{|c|}{ Business, residential, etc., } & - & $\cdot$ & . & - & 7,330 & - & 30 \\
\hline Water, - . & - & - & . & - & - & 690 & - & 3 \\
\hline \multicolumn{2}{|c|}{ Total area of town,. } & . & . & . & - & 24,640 & - & 100 \\
\hline
\end{tabular}




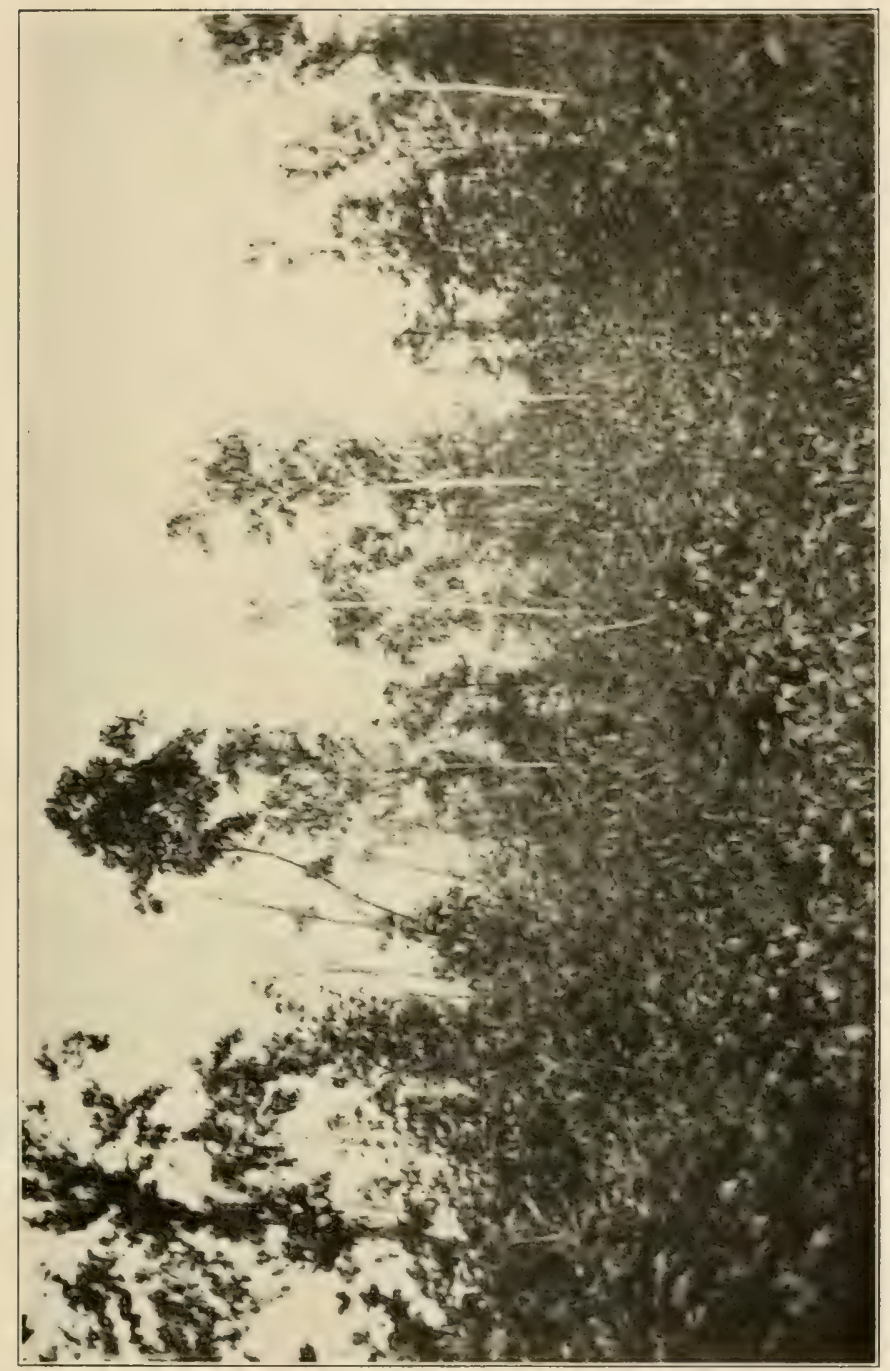

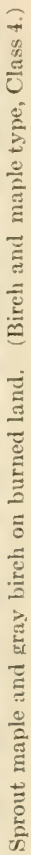





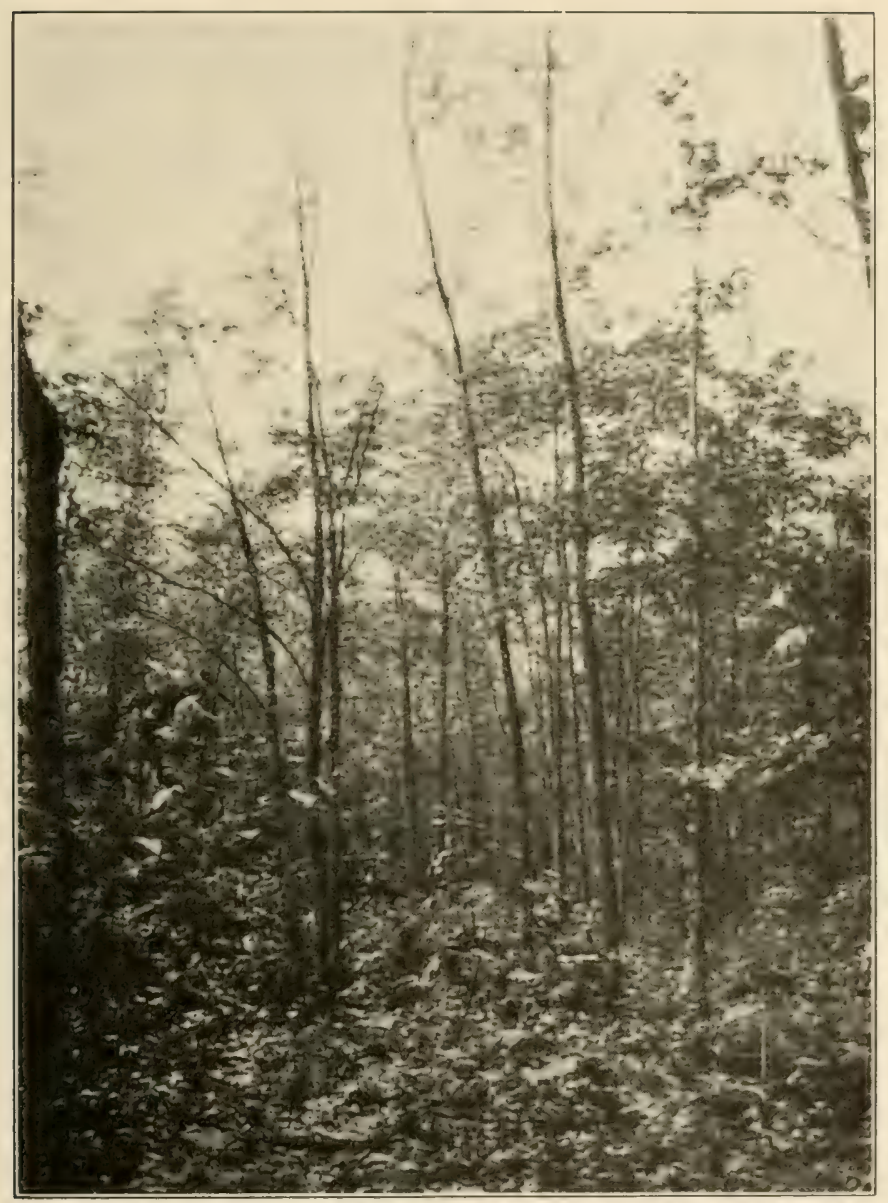

IRed maple in swamp. Diameters, 3 to 7 inches; heights, 35 to 45 feet. (Maple and birch type, Class 3 .) 


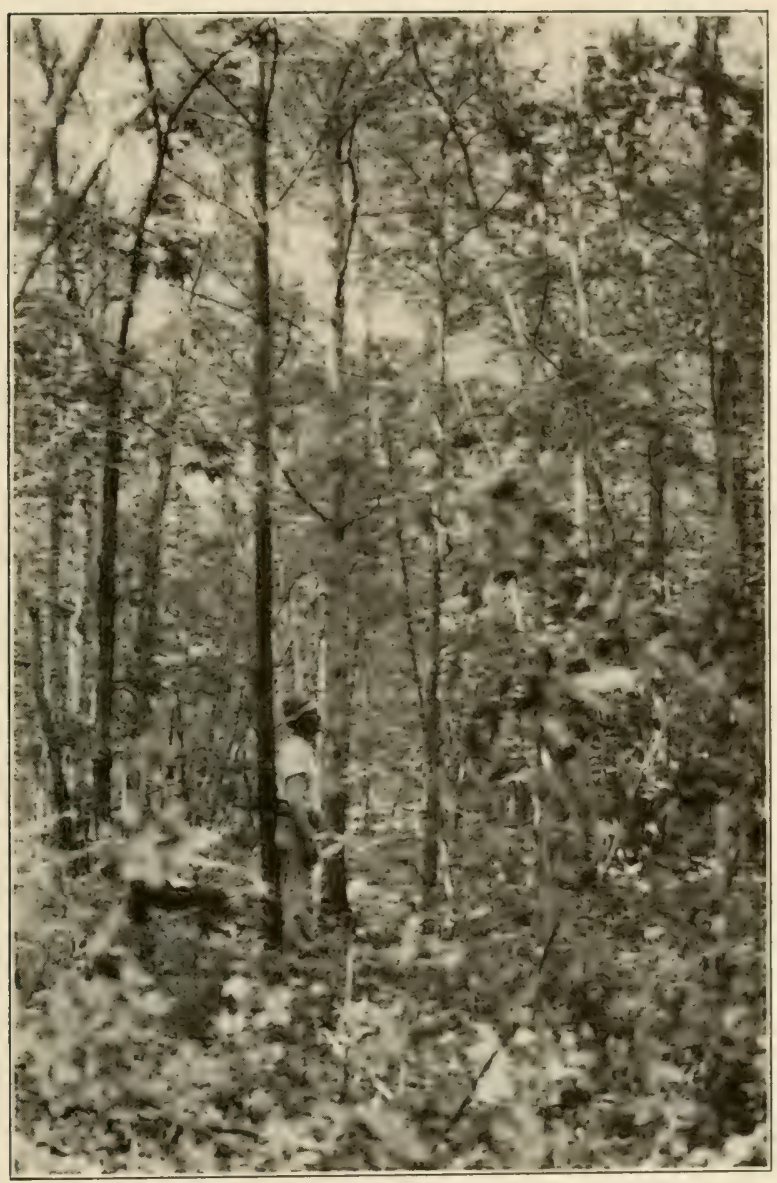

()ak, maple and pine in mixture, Diameters, 3 to 7 inches; heiglit 20 to 30 feet. (Pine and hardwoods type, Class 3.) 



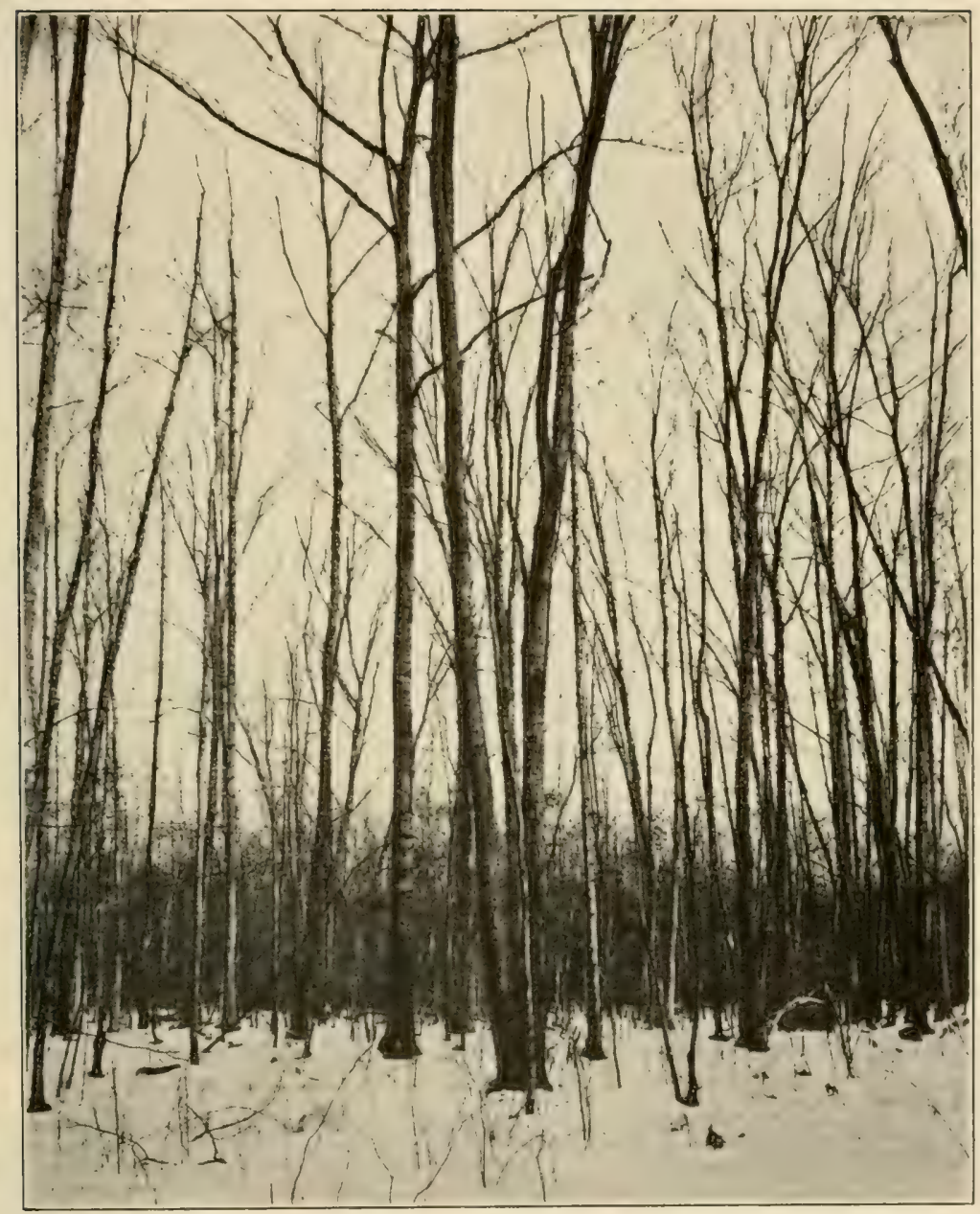

Large sprout oak. Diameters, 7 to 12 inches; heights, 50 to 60 feet (Oak type, Class 2.) 



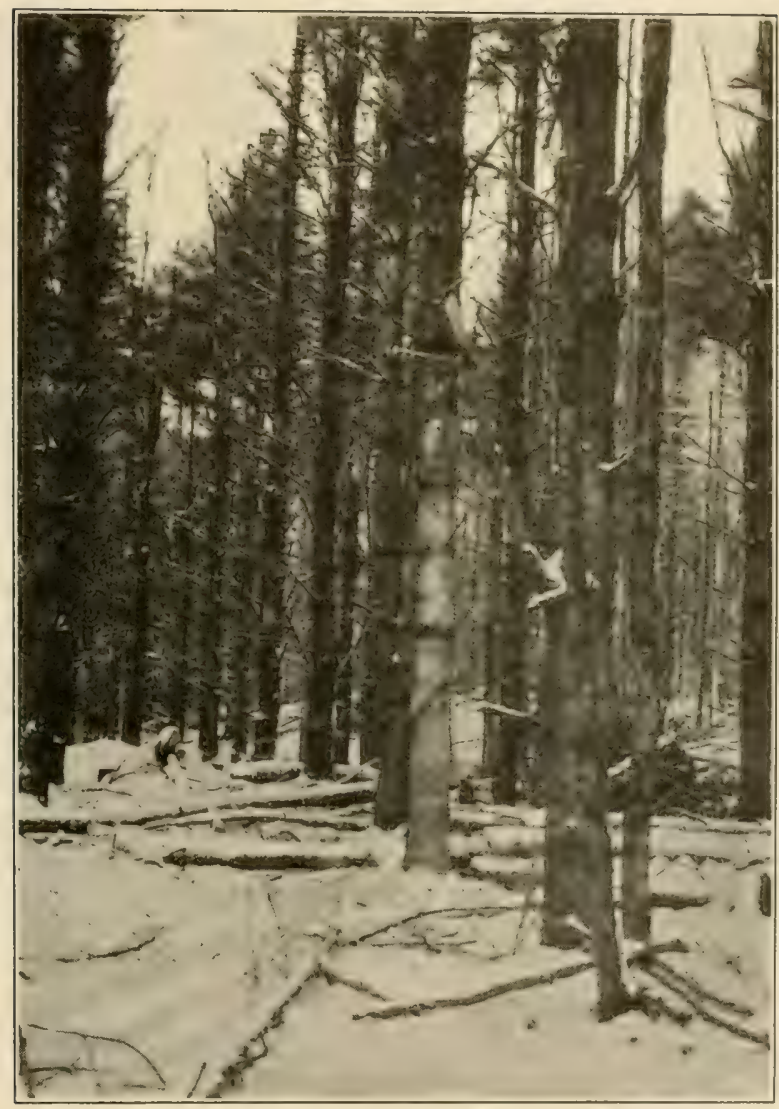

White pine fifty years old. Diameters, 8 to 13 inches; heights, 5.5 to 6.5 feet. (White pine type, Class 2.) 



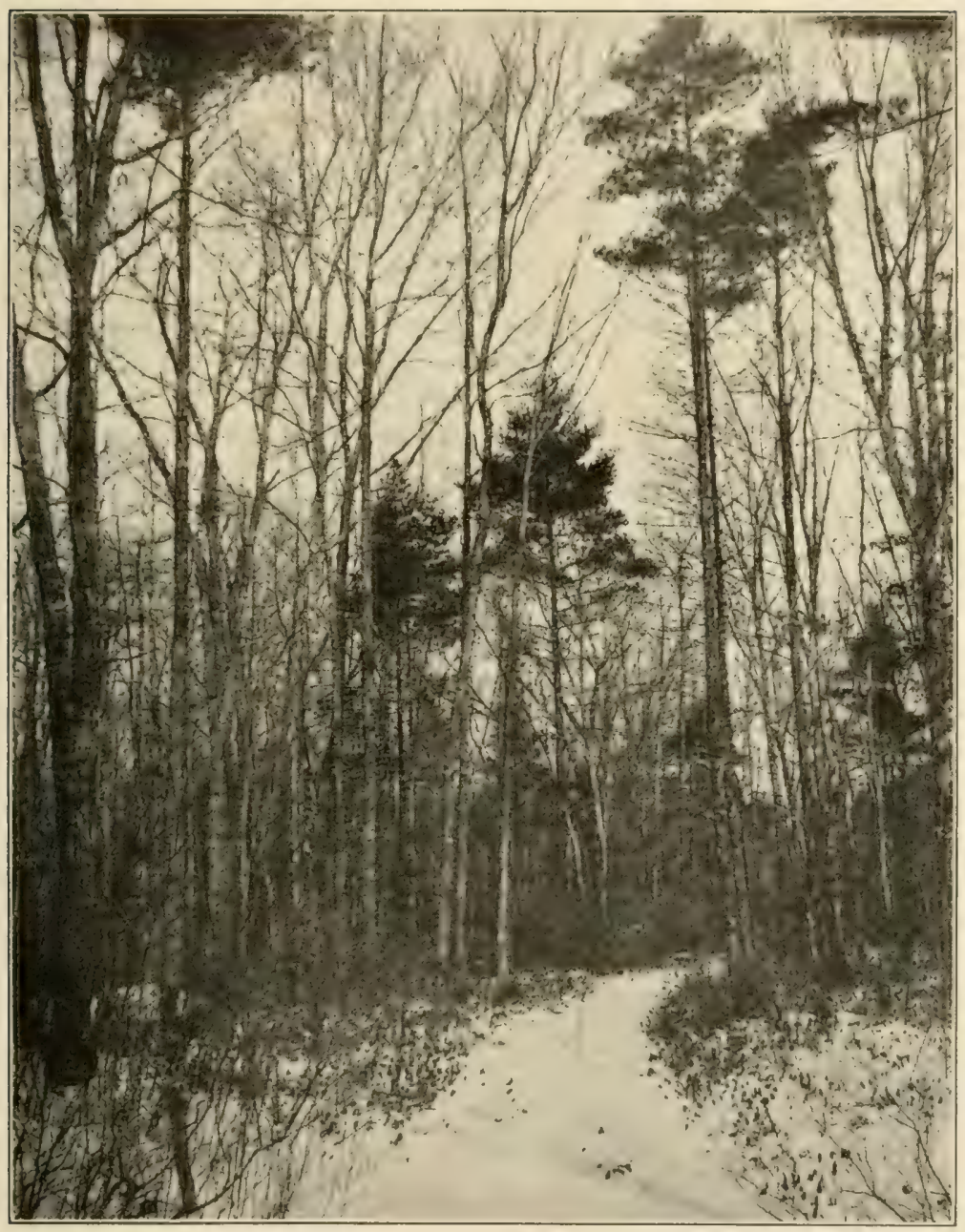

Pine, maple and oak. Diameters, 6 to 10 inches; heights, 50 to 60 feet. (Pine and hardwoods type, Class 2.) 



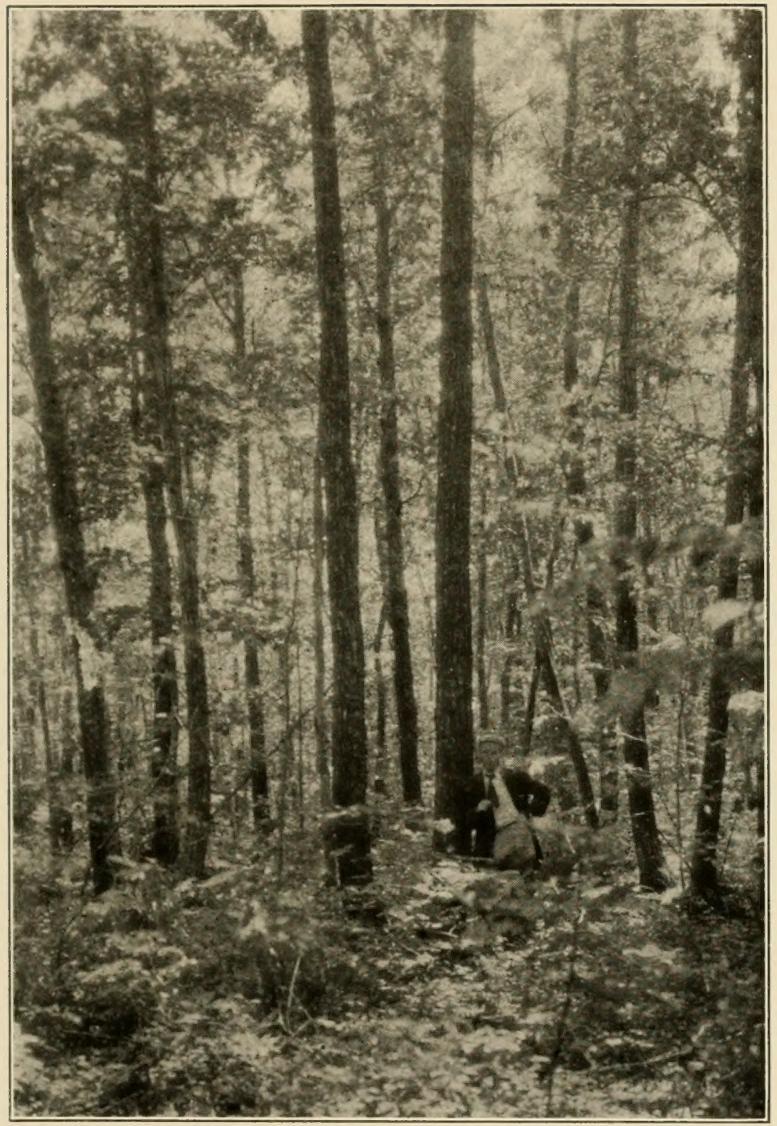

Large sprout chestnut. Diameters, 8 to 14 inches; heights, 60 to 70 feet. (Chestnut type, Class 1.) 

LIBRARY OF CONGRESS

||||||||||||||||||||||||||||||||||||||||||||||||||||||||||||||||||||||||||||||

00008 ?9998 